San Jose State University

SJSU ScholarWorks

Master's Theses

Master's Theses and Graduate Research

Summer 2017

\title{
Construction and Emplacement of Cretaceous Plutons in the Crystal Range, Southwest of Lake Tahoe, California
}

Brad Buerer

San Jose State University

Follow this and additional works at: https://scholarworks.sjsu.edu/etd_theses

\section{Recommended Citation}

Buerer, Brad, "Construction and Emplacement of Cretaceous Plutons in the Crystal Range, Southwest of Lake Tahoe, California" (2017). Master's Theses. 4837.

DOI: https://doi.org/10.31979/etd.eyj9-3w7m

https://scholarworks.sjsu.edu/etd_theses/4837

This Thesis is brought to you for free and open access by the Master's Theses and Graduate Research at SJSU ScholarWorks. It has been accepted for inclusion in Master's Theses by an authorized administrator of SJSU ScholarWorks. For more information, please contact scholarworks@sjsu.edu. 
CONSTRUCTION AND EMPLACEMENT OF CRETACEOUS PLUTONS IN THE

CRYSTAL RANGE, SOUTHWEST OF LAKE TAHOE, CALIFORNIA

\author{
A Thesis \\ Presented to \\ The Faculty of the Department of Geology \\ San José State University \\ In Partial Fulfillment \\ of the Requirements for the Degree \\ Master of Science
}

by

Brad Buerer

August 2017 
(C) 2017

Brad Buerer

\section{ALL RIGHTS RESERVED}


The Designated Thesis Committee Approves the Thesis Titled

CONSTRUCTION AND EMPLACEMENT OF CRETACEOUS PLUTONS IN THE CRYSTAL RANGE, SOUTHWEST OF LAKE TAHOE, CALIFORNIA

by

Brad Buerer

APPROVED FOR THE DEPARTMENT OF GEOLOGY

SAN JOSÉ STATE UNIVERSITY

August 2017

Dr. Robert Miller

Department of Geology

Dr. Jonathan Miller

Department of Geology

Dr. Dave Andersen

Department of Geology 


\title{
ABSTRACT \\ CONSTRUCTION AND EMPLACEMENT OF CRETACEOUS PLUTONS IN THE CRYSTAL RANGE, SOUTHWEST OF LAKE TAHOE, CALIFORNIA
}

\author{
by Brad Buerer
}

Three Cretaceous plutons are investigated to determine their construction and emplacement histories, focusing on magmatic foliation patterns and contact relationships with each other and with the Jurassic metasedimentary host rocks of the Sailor Canyon Formation. The earliest Cretaceous Pyramid Peak granite is a leucocratic pluton with extensive co-magmatic diorite and granite-diorite hybrid rock. It contains a single NNW -striking magmatic foliation that probably reflects the regional stress field at the time of crystallization. The granite was constructed by multiple magmatic increments, though internal contacts are scarce in homogeneous parts of the pluton. Emplacement was accommodated by roof uplift, a modest degree of floor sinking, and the brittle transfer of host via stoping. The mid-Cretaceous Wrights Lake granodiorite is largely homogeneous, except near the margin, and has abundant microgranitoid enclaves and schlieren. This granodiorite has two overprinting magmatic foliations: a contact-parallel foliation that is interpreted to reflect filter pressing and/or flow of magma against the margin, and an east-west discordant foliation that reflects regional strain. Xenoliths of Sailor Canyon Formation and Pyramid Peak granite are common near the margin, demonstrating stoping. The markedly homogenous, weakly foliated Tyler Lake granodiorite has poorly exposed contacts and few conclusions could be made about its history, but brittle transfer of host probably played a role. Plutons in the region document a transition in the regional strain field between the early and middle Cretaceous. 


\section{ACKNOWLEDGMENTS}

I would like to thank everyone involved in helping me accomplish this task. Thanks to my friends and family for supporting me and encouraging me to get through this thing. Thanks to my trusty field assistants Mireya Berrios, Chris Bonnette, Pablo Cortez, and Monika Leopold for keeping me company in the field, preventing me from dying, and helping find cool stuff in rocks. Thanks to Alphonse Odisho for listening to me whine about the old rock saw and for all the assistance back on campus. Thanks to my thesis committee members, Jonathan Miller and Dave Andersen, for guiding me through my undergrad and grad school adventures and for helping me pull this document together. And thanks to my advisor, Bob Miller, for inspiring me to pursue geology in the first place, many, many (many) years ago, for guiding me through this wild journey of perplexing plutonic puzzles, and for providing endless ideas and suggestions that made this thesis far better than it could have been otherwise. I would also like to thank the Geological Society of America for providing partial funding through a student research grant. 


\section{TABLE OF CONTENTS}

LIST OF FIGURES viii

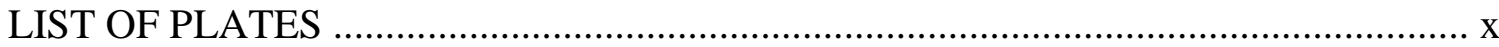

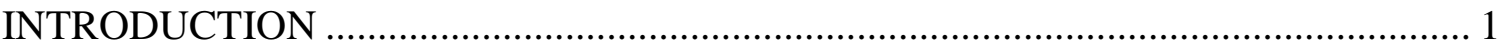

Geologic Setting............................................................................................ 5

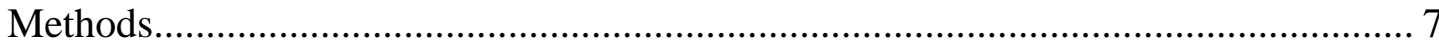

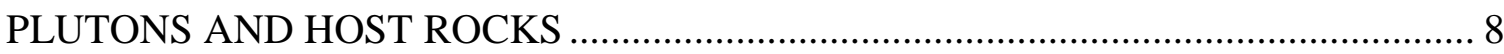

Sailor Canyon Formation ................................................................................ 8

Pyramid Peak Granite ……………………………………………………………... 10

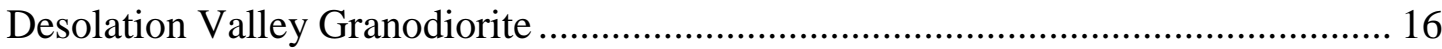

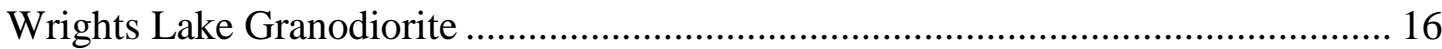

Tyler Lake Granodiorite ………………………………………………………. 25

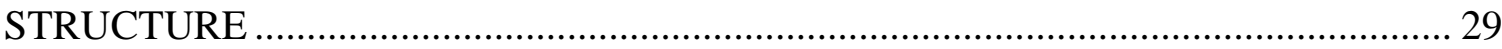

Folding of the Sailor Canyon Formation ……………………………………….... 29

Mineral Fabric Patterns............................................................................................. 31

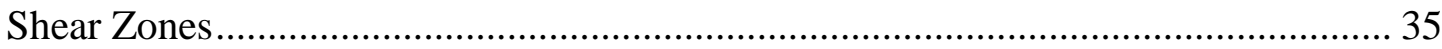

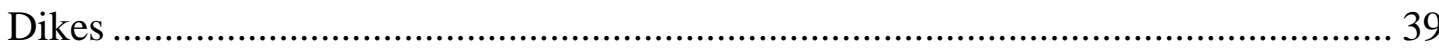

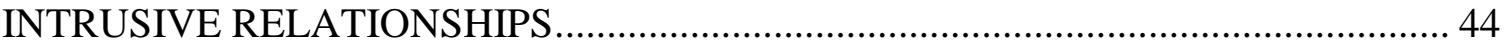

Pyramid Peak Granite - Sailor Canyon Formation Contact......................................... 44

Wrights Lake Granodiorite - Sailor Canyon Formation Contact................................. 50

Wrights Lake Granodiorite - Pyramid Peak Granite Contact ...................................... 53

Tyler Lake Granodiorite - Pyramid Peak Granite Contact ............................................ 54

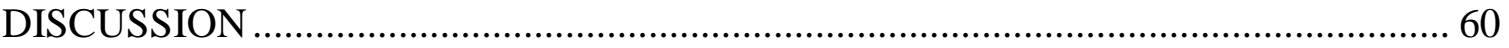

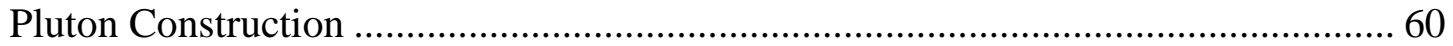


Construction of the Pyramid Peak Granite …………............................................ 60

Construction of the Wrights Lake Granodiorite ………………………………..... 63

Construction of the Tyler Lake Granodiorite..................................................... 65

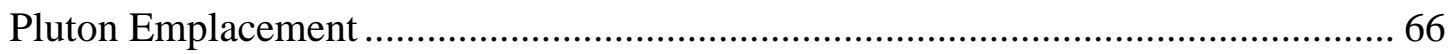

Emplacement of the Pyramid Peak Granite .......................................................... 67

Emplacement of the Wrights Lake Granodiorite .................................................. 70

Emplacement of the Tyler Lake Granodiorite ...................................................... 73

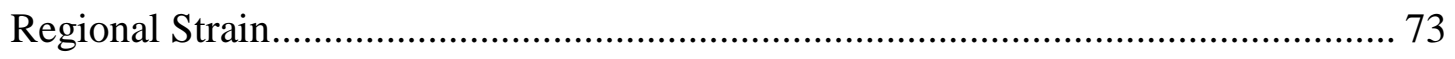

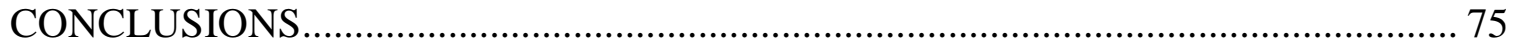

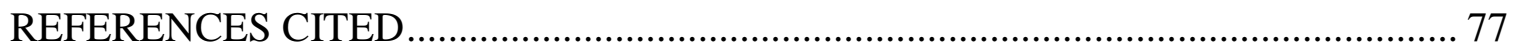




\section{LIST OF FIGURES}

Figure 1. Simplified geologic map of the Crystal Range and surroundings, modified from Saucedo (2005).

Figure 2. Simplified geologic map of the study area, modified from Saucedo (2005)... 6

Figure 3. Concretion in fractured siltstone of Sailor Canyon Formation....................... 9

Figure 4. Enclave swarms within the Pyramid Peak granite........................................ 13

Figure 5. Features within Pyramid Peak granite enclave swarms............................... 14

Figure 6. Mingling relationships between standard and leucocratic Wrights Lake granodiorite.

Figure 7. Amorphous 1.8-m-diameter schlieren "blob" in the Wrights Lake granodiorite

Figure 8. Offset microgranitoid enclaves in the Wrights Lake granodiorite.

Figure 9. Cluster of rounded enclaves in the Wrights Lake granodiorite.

Figure 10. Enclave accumulations near the margin of the Wrights Lake granodiorite.... 23

Figure 11. Syn-plutonic dike of enclaves in Wrights Lake granodiorite....................... 24

Figure 12. Felsic dike in Tyler Lake granodiorite................................................... 27

Figure 13. Hydrothermal pipes in the Tyler Lake granodiorite.................................. 28

Figure 14. Poles to beds of the Sailor Canyon Formation........................................... 30

Figure 15. Tight to isoclinal folds within the Sailor Canyon Formation........................ 31

Figure 16. Poles of foliations within the Pyramid Peak granite...................................... 32

Figure 17. Photomicrograph of solid-state deformation in Pyramid Peak granite of

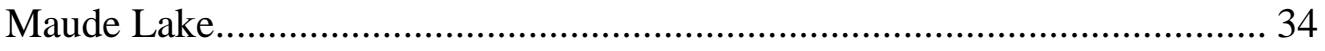

Figure 18. Poles of foliations within the Wrights Lake granodiorite............................ 36

Figure 19. Poles of foliations within the Tyler Lake granodiorite ................................ 37

Figure 20. Poles to shear zones within the Pyramid Peak granite.................................. 38 
Figure 21. Poles to mafic dikes in the Pyramid Peak granite.

Figure 22. Short mafic dikes crossing the contact of the Wrights Lake granodiorite and Pyramid Peak granite.

Figure 23. Vertical face of Wrights Lake granodiorite intruded by aplite dikes.

Figure 24. Small, unbedded, angular xenoliths of Sailor Canyon Formation in the Pyramid Peak granite

Figure 25. Lenticular xenoliths of Sailor Canyon Formation in the Pyramid Peak granite 46

Figure 26. Pyramid Peak granite intruded concordantly between parallel rafts of bedded Sailor Canyon Formation

Figure 27. Non-planar bodies of Pyramid Peak granite discordantly intrude the Sailor Canyon Formation.

Figure 28. Wrights Lake granodiorite cuts discordantly through steep bedding of a Sailor Canyon Formation xenolith

Figure 29. Wrights Lake granodiorite infiltrates Sailor Canyon Formation xenoliths.... 52

Figure 30. Angular protrusion of Pyramid Peak granite into Wrights Lake granodiorite.

Figure 31. Xenoliths and xenocrysts of Pyramid Peak granite within the Wrights Lake granodiorite.

Figure 32. 2-m-long rectangular xenolith of Pyramid Peak granite in the Wrights Lake granodiorite

Figure 33. Intrusive contact of the Tyler Lake granodiorite with the diorite of the Pyramid Peak granite. 


\section{LIST OF PLATES}

Plate 1. Geologic Map of the West Central Crystal Range, Southwest of Lake Tahoe, California.............................................................. supplemental 


\section{INTRODUCTION}

Granitic plutons have long been the subject of study, but their construction and emplacement remain controversial. Plutons exhibit a large range of sizes, shapes, and compositions, and intrude at a wide variety of crustal depths, in different tectonic settings, and into a range of host materials. These variables, together with the threedimensional limitations of pluton exposure, have made it a challenge to establish universal models for the construction and emplacement of plutons.

Many plutons show evidence for incremental construction by multiple injections of magma, yet there is much debate regarding the size, shape, orientation, and timing of the magma injections, as well as whether the injections are of the necessary scale and frequency to establish a magma chamber (e.g., Wiebe and Collins, 1998; Miller and Paterson, 2001; Coleman et al., 2004; Glazner et al., 2004; Matzel et al., 2006; Barbey et al., 2008; Miller et al., 2011; Paterson et al., 2011; Eddy et al., 2016). Previous workers have proposed a variety of models for magma ascent and final construction at the emplacement level. These end-member models range from the classic concept of a massive pluton-scale surge of magma (e.g., Bateman and Chappell, 1979), to multiple, amalgamated diapiric injections of magma of varying shapes and sizes (e.g., Paterson and Vernon, 1995; Miller and Paterson, 1999), to a coalescence of overlapping, coeval or discrete dike injections (e.g., Pitcher and Berger, 1972; Mahan et al., 2003; Glazner et al., 2004; Brown, 2013). It can be difficult to recognize mechanisms of pluton construction due to the limitations of pluton exposures, which are typically only a thin, sub-horizontal slice through a much larger, three-dimensional body. In addition, some workers have 
argued that internal contacts between individual increments within a pluton may be present, but not readily visible, making them very difficult to discern (e.g., Mahan et al., 2003; Glazner et al., 2004).

One distinct type of pluton construction has been described by Wiebe $(1993 ; 2016)$. Some granitic plutons, such as the Kameruka granodiorite of southeastern Australia, Pleasant Bay intrusion and Vinalhaven granite of Maine, and Aztec Wash pluton of Nevada, are shown to have been constructed by alternating, subhorizontal mafic and silicic sheets (Wiebe, 1993; Wiebe and Collins, 1998; Harper et al., 2004; Wiebe et al., 2004; Wiebe, 2016). Each mafic layer within these mafic-silicic layered intrusions (MASLI) features a chilled margin at its base and evidence of mechanical mixing and/or compositional gradients at its upper contact with the overlying silicic magma (Wiebe, 1996; Wiebe et al., 2002). These observations are interpreted to record periodic intrusions of mafic magma, which pond on the aggrading crystal-rich floor of a crystalpoor granitic magma chamber. One of the plutons of this study, the Jurassic Pyramid Peak granite, is interpreted to be a MASLI by Wiebe et al. (2002), on the basis of their work directly south of this study area.

Multiple models are also proposed for magma emplacement to explain the displacement of host material necessary to accommodate the magma. Hypotheses invoked to explain how this material is transferred include: ductile straining of wall material; stoping of host material as xenoliths; dilation by fault extension; sinking of floor material below a pluton; uplifting the roof of a pluton; and wedging aside of host rocks by sheets (e.g., Buddington, 1959; Pitcher and Berger, 1972; Corry, 1988; Hutton, 
1996; Paterson et al., 1996; Wiebe and Collins, 1998; Cruden and McCaffrey, 2001; Miller and Paterson, 2001). As with pluton construction, the determination of emplacement mechanisms is limited by the relatively small vertical relief of exposures.

Magmatic foliations are an important record of processes occurring in the late stages of pluton crystallization, and can preserve evidence of internal flow, filter pressing, or regional tectonic strain (Paterson et al., 1998). Previous workers have observed that multiple overprinting foliation patterns are present in at least a few plutons, including the Tuolumne batholith in California (Žák et al., 2007), Main Donegal pluton in Ireland, and Entiat and Mount Stuart plutons in Washington (Paterson et al., 1998). These fabrics may record both the regional tectonic strain field and the internal magmatic processes active in the late stages of pluton development (Žák et al., 2008).

This study focuses on the magmatic foliation patterns, internal magmatic features, and contact relationships of the well-exposed Jurassic and Cretaceous plutons of the west-central portion of the Crystal Range, a short ( $16 \mathrm{~km})$ mountain range $<12 \mathrm{~km}$ southwest of Lake Tahoe (Fig. 1) within the Sierra Nevada batholith of California. Documenting the construction and emplacement of the Jurassic Pyramid Peak granite and Cretaceous Wrights Lake and Tyler Lake granodiorites of the Crystal Range should provide insights applicable to other plutons in the northern part of the Sierra Nevada batholith and similar arc settings. In addition, the foliation patterns may provide important records of the regional strain field at the time of crystallization of the three plutons. 


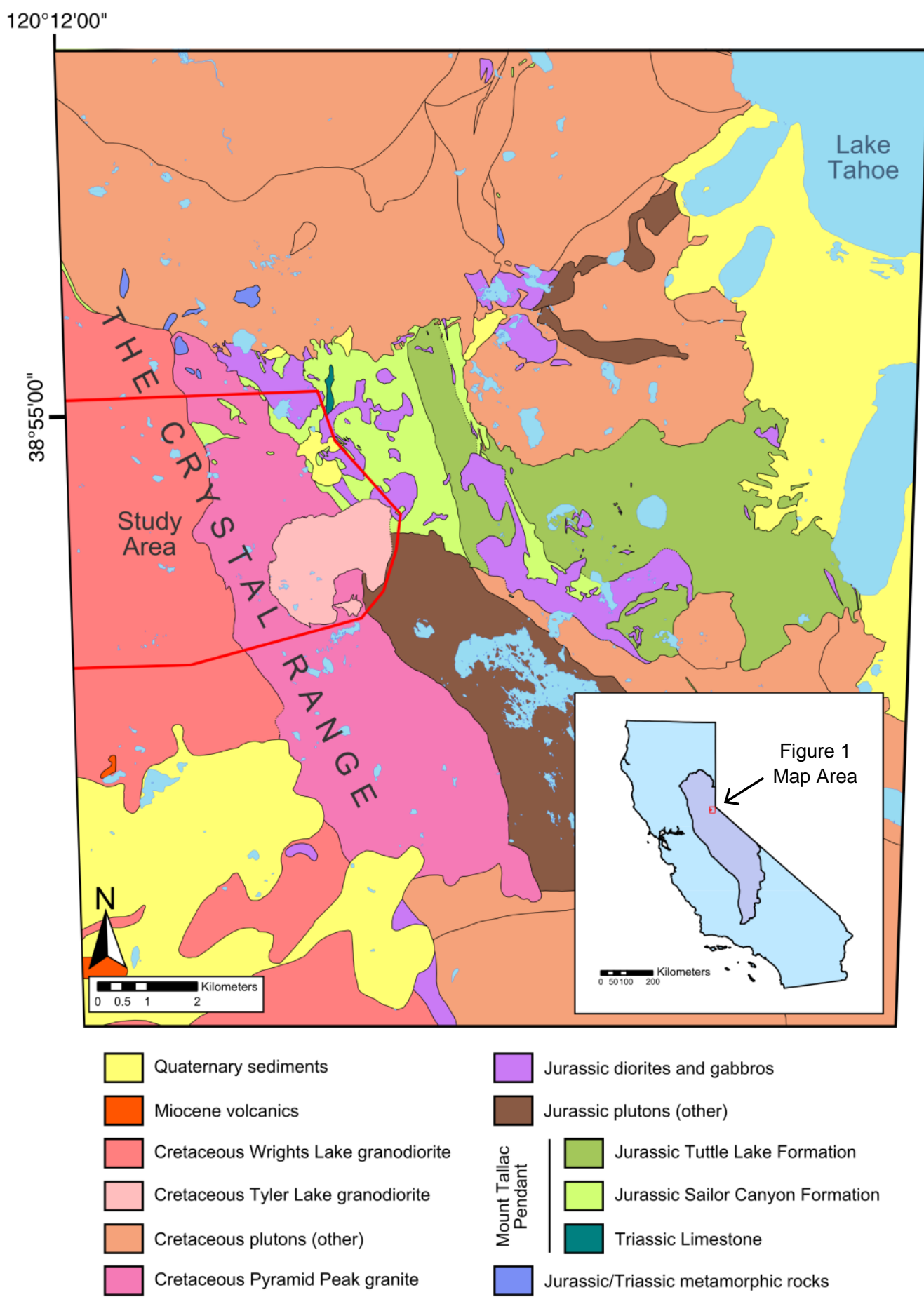

Figure 1. Simplified geologic map of the Crystal Range and surroundings, modified from Saucedo (2005). Bold red boundary on left side marks the study area. Inset shows the location of Figure 1 relative to the Sierra Nevada batholith of California. 


\section{Geologic Setting}

The Sierra Nevada batholith of eastern California is part of the Mesozoic arc formed during the subduction of the Farallon plate beneath the North American craton (e.g., Atwater, 1970, 1989; Hamilton, 1978). The plutons of the Crystal Range are part of the northeastern exposure of the batholith (Fig. 1). Host rocks in the Crystal Range are metamorphosed marine sedimentary rocks known as the Mount Tallac pendant. The Late Triassic to Jurassic rocks of the pendant were deposited during a time of extensionrelated subsidence and record a transition from shallow-water to deep-water conditions (Fisher, 1990).

The formerly Jurassic Pyramid Peak granite predates the other plutons it contacts both within and beyond the study area (Saucedo, 2005). It intrudes the Early to Middle Jurassic Sailor Canyon Formation of the Mount Tallac pendant in the northern and northeastern portions of the study area (Fig. 2). East of the Pyramid Peak granite, parts of one or more unnamed and undifferentiated mafic bodies also intrude the Sailor Canyon Formation (Loomis, 1983; Fisher, 1990; Saucedo, 2005), but were not a focus of this study (Figs. 1 and 2).

A large (>775 km²; Loomis, 1983) Cretaceous pluton, the Wrights Lake granodiorite, intrudes the entire western margin of the Pyramid Peak granite. A second, much smaller $\left(>4 \mathrm{~km}^{2}\right)$ Cretaceous pluton, the Tyler Lake granodiorite, intrudes the Pyramid Peak granite in the southern portion of the study area. The Tyler Lake granodiorite is surrounded by the Pyramid Peak granite, except on its eastern margin, 
where the granodiorite intrudes the Sailor Canyon Formation, unnamed mafic bodies, and the Jurassic Desolation Valley granodiorite, a pluton which was not studied for this project (Fig. 2 and Plate 1; Loomis, 1983).

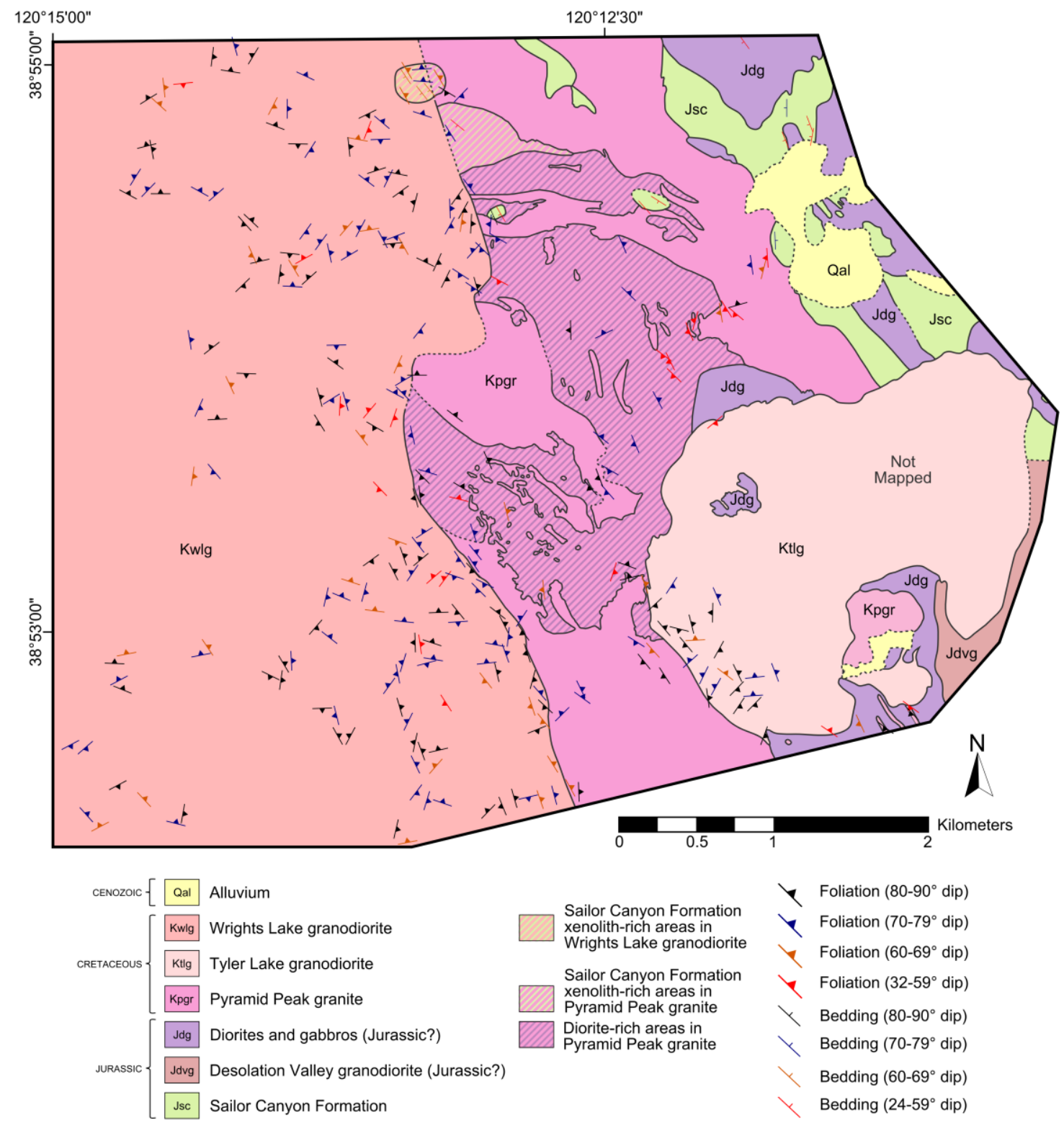

Figure 2. Simplified geologic map of the study area, modified from Saucedo (2005). Structural data are colored according to steepness of dip angle. See Plate 1 for detailed geologic map, including specific dip numbers and other structural features. 


\section{Methods}

The goal of this thesis is to evaluate the construction, emplacement, and structure of the Pyramid Peak granite, Wrights Lake granodiorite, and Tyler Lake granodiorite. To

facilitate this analysis, an existing 1:100,000 geologic map (Saucedo, 2005), compiled in part from the previous work of Loomis (1981), Fisher (1990), and Sabine (1992), was refined at a scale of 1:24,000, with a focus on contact relations, internal magmatic structures, and magmatic and solid-state foliation orientations. The fabric intensity, grain size, and favorable color index of the Wrights Lake granodiorite allowed for the acquisition of extensive foliation orientation data, and rare lineation orientations. Fewer orientations were measured in the other two plutons, due to the weakness of fabrics.

Pluton-host contacts were traced in order to characterize the relationships between units and to determine the processes that accommodated emplacement. Internal features of the plutons, including enclaves, schlieren, pipes, and coeval and younger dikes were also studied to provide insights into magmatic processes. A total of 21 thin sections provided for petrographic and microstructural analysis. 


\section{PLUTONS AND HOST ROCKS}

\section{Sailor Canyon Formation}

The metasedimentary Sailor Canyon Formation is the predominant host rock for the plutons of the study area (Fig. 2). It is part of a sequence of rocks described as the Mount Tallac pendant, an informal group consisting of three subunits that appear to form a broad anticline with a roughly north-south axis, based on map patterns (Fig. 1; Saucedo, 2005). An unnamed Upper Triassic limestone, exposed only in the core of the anticline directly east of the study area, is overlain by the Lower to Middle Jurassic Sailor Canyon Formation (Fisher, 1989; Harwood et al., 2014). The youngest unit of the pendant, the overlying Middle to Upper Jurassic Tuttle Lake Formation, is exposed only to the east of the study area, in the eastern limb of the fold (Fisher, 1989, 1990).

The Sailor Canyon Formation is typically a blue or gray, massive or parallellaminated quartzo-feldspathic siltstone. Its Early to Middle Jurassic age is established by Early Jurassic (late Pliensbachian) ammonites just east of the study area (Fisher, 1990). Grain size and mode vary by outcrop, but the few collected samples are primarily finegrained and equigranular with isolated larger grains up to $1.5 \mathrm{~mm}$ in length. The typical mineral assemblage includes quartz, plagioclase, hornblende, and biotite. Epidote and white mica are secondary minerals. Biotite shows minor chloritization. Quartz is typically the most abundant mineral. One sample, however, is dominated by plagioclase and includes subhedral plagioclase crystals as large as $3.5 \mathrm{~mm}$. Some outcrops contain concretions of a fine-grained green mineral. The concretions range from 4 to $12 \mathrm{~cm}$ in length and have aspect ratios of around 2:1 to 3:1 (Fig. 3). These siltstones have been 


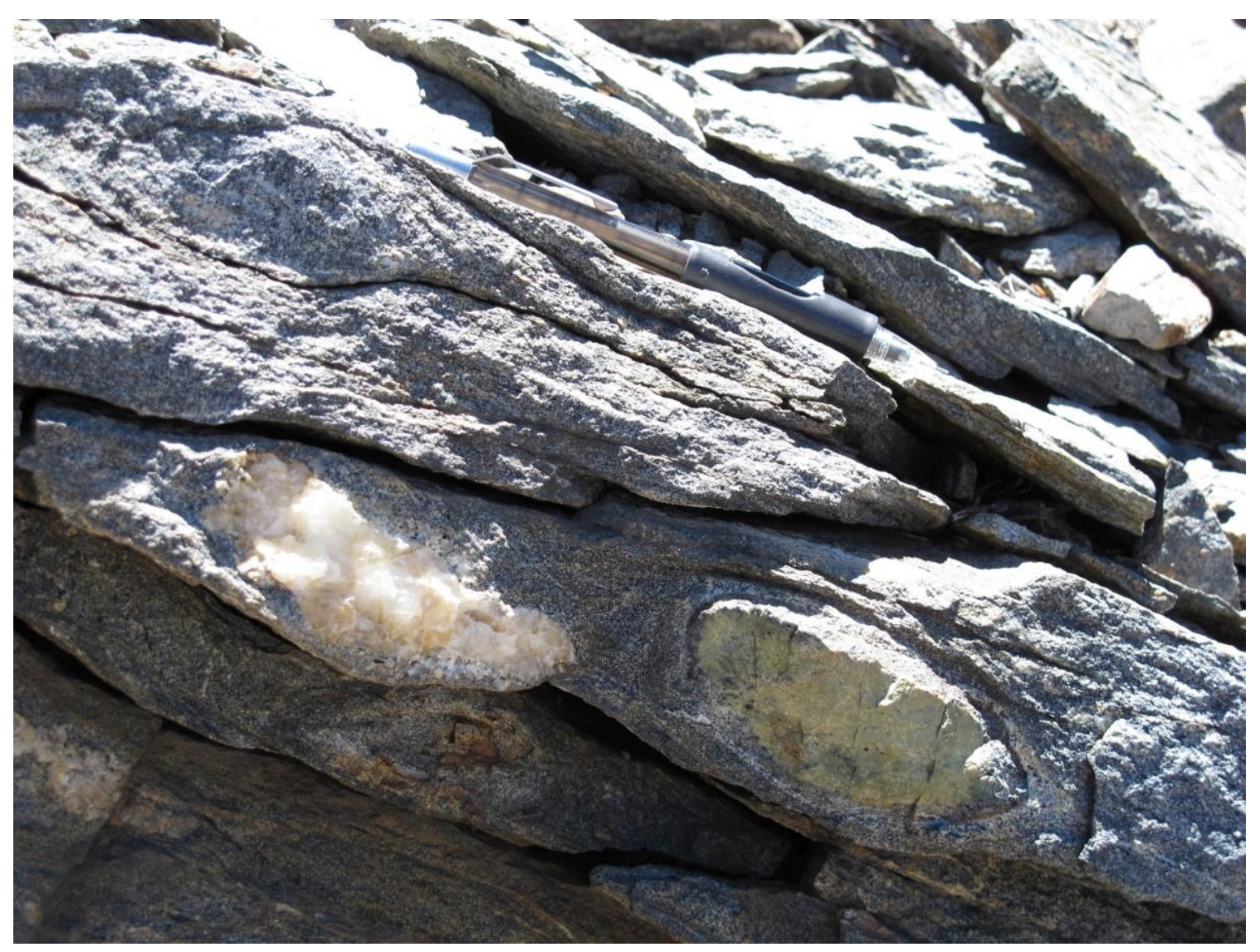

Figure 3. Concretion in fractured siltstone of Sailor Canyon Formation. Long axis of concretion is parallel to beds. $14-\mathrm{cm}$ mechanical pencil for scale.

altered by contact metamorphism. Loomis (1983) stated that these rocks were metamorphosed to hornblende hornfels facies, indicating a medium temperature at an upper-crustal pressure.

A very fine-grained, impure quartzite makes up an isolated, roughly $3,000 \mathrm{~m}^{2}$ pendant within the Pyramid Peak granite east of Lawrence Lake (Plate 1). The rock is blue and parallel-laminated in hand sample. In thin section, it is heterogeneous in both mineral composition and grain size. The majority of the rock is recrystallized quartz, which rarely reaches up to $0.5 \mathrm{~mm}$. Fe-Ti oxides make up as much as $5 \%$ of the rock in places, 
and larger crystals reach up to $0.3 \mathrm{~mm}$. Chlorite appears in patches, and forms the rims of some Fe-Ti oxides. Another mineral also appears in patches and is likely diopside. The Fe-Ti oxides, chlorite, and diopside grade from being the dominant material in places to being absent entirely. Plagioclase makes up less than $1 \%$ of the sample.

Beds and laminae in the Sailor Canyon Formation generally range from 0.5 to $2 \mathrm{~cm}$ in thickness. In some outcrops, the rock cleaves along layers into centimeter-thick plates. Within the main pendant of the Sailor Canyon Formation on the northeast side of the study area, in the vicinity of Lake Doris (Plate 1), beds and laminae are as thin as 1-4 mm. One outcrop near Lake Doris appears to have a single Bouma sequence consisting of Tb-Td divisions. Thin millimeter-scale laminae are overlain by cross-beds, and finergrained layers occur at the top of the sequence. The entire sequence is less than $50 \mathrm{~cm}$ in thickness. Some outcrops contain open to tight folds, which are described in the Structure section.

\section{Pyramid Peak Granite}

The formerly Jurassic Pyramid Peak granite is the oldest of the plutons within the study area, based on field relations. It has a published U-Pb zircon age of $164 \pm 7 \mathrm{Ma}$ (Sabine, 1992), although an unpublished, much higher-precision U-Pb zircon date obtained by chemical abrasion isotope dilution thermal ionization mass spectrometry (CA-ID-TIMS) is 20 myr younger at $144.515 \pm 0.027 \mathrm{Ma}$ (M. Eddy, written communication), placing it in the earliest Cretaceous. This pluton will be described as earliest Cretaceous for the remainder of this thesis (Plate 1 and Fig. 2). The original pluton margins are only exposed where the Pyramid Peak granite intrudes the Sailor 
Canyon Formation. Late Jurassic(?) and Cretaceous plutons intrude the Pyramid Peak granite on all other sides.

Overall, the Pyramid Peak granite is leucocratic, but it also contains widespread mafic rocks with both sharp and gradational boundaries with the leucocratic rocks. The felsic portion of the pluton ranges from granite to quartz monzonite. These rocks are characterized by large, tabular K-feldspar phenocrysts, which reach lengths of $1.2 \mathrm{~cm}$ where the unit is coarsest. These phenocrysts define a magmatic foliation. The Kfeldspar crystals are either microcline or orthoclase, depending on the outcrop, and typically comprise around $35-40 \%$ of the mode, but can reach up to 50\%. Anhedral quartz is typically $35-45 \%$ of the rock, but decreases to $20 \%$ where $\mathrm{K}$-feldspar is concentrated. Plagioclase modes range from 10-25\%. Myrmekite is common. Color index is generally less than 5 , with biotite and minimal hornblende as the mafic minerals. Accessory minerals include allanite, sphene, zircon, hematite, and Fe-Ti oxides. Biotite alters into epidote and rarely chlorite. In a few areas on the western margin, near the contact with the Wrights Lake granodiorite, an increase in fine-grained biotite gives the granite a darker overall appearance (5-10 color index). Transitions to darker rock are generally gradational.

Microgranitoid enclaves are sparse in the felsic rocks, but at one locality there are several tightly packed swarms, with enclaves numbering into the thousands. These swarms reach sizes of up to 8 by $11 \mathrm{~m}$. Individual enclaves within the swarms are finegrained and equigranular, have a color index of $\sim 40$, and range from round, fist-sized enclaves of low aspect ratio ( 2:1) (Fig. 4A) to more elongate enclaves ( 7:1 to 12:1) 
(Fig. 4B). At the centers of the swarms, the enclaves are strongly aligned with a northeast trend, which differs from the overall northwest strike of magmatic fabric of the pluton. At the swarm edges, enclaves show a margin-parallel orientation and mark a discrete boundary with the surrounding granite. Thinner channel-like bodies of enclaves connect larger swarms. One of the channels is folded with an interlimb angle of about $80^{\circ}$ (Fig. 5A). Another enclave channel has been truncated by a different pulse of magma, and the enclaves are sheared out along an internal contact (Fig. 5B).

A second zone of enclaves is exposed near the contact with the southern margin of the Tyler Lake granodiorite. These enclaves are equigranular and hydrothermally altered, having thin $(1-1.5 \mathrm{~cm})$ rims of biotite and hornblende, and cores rich in fine-grained epidote, which gives them a distinctive green appearance. These enclaves have a low aspect ratio $(\sim 1: 1)$ and the largest are $14 \mathrm{~cm}$ in diameter. The enclaves number into the hundreds with concentrations reaching up to 15 per square meter.

The granite of the Pyramid Peak pluton is coeval with rocks mapped previously as "Jurassic diorites and gabbros" (Saucedo, 2005). Samples collected for this study are dioritic based on color index, and are in some cases quartz diorites and tonalites, as detailed below. Loomis (1981) identified gabbro near or within the study area, but for the sake of simplicity, all of the intermediate to mafic rocks within the pluton are herein referred to as diorite. The diorites range from meter-scale patchy masses to kilometerscale bodies. Some bodies are entirely dioritic, with one exceeding $0.5 \mathrm{~km}^{2}$, but in most localities, granitic material is intermixed with diorite. The diorite is commonly separated 

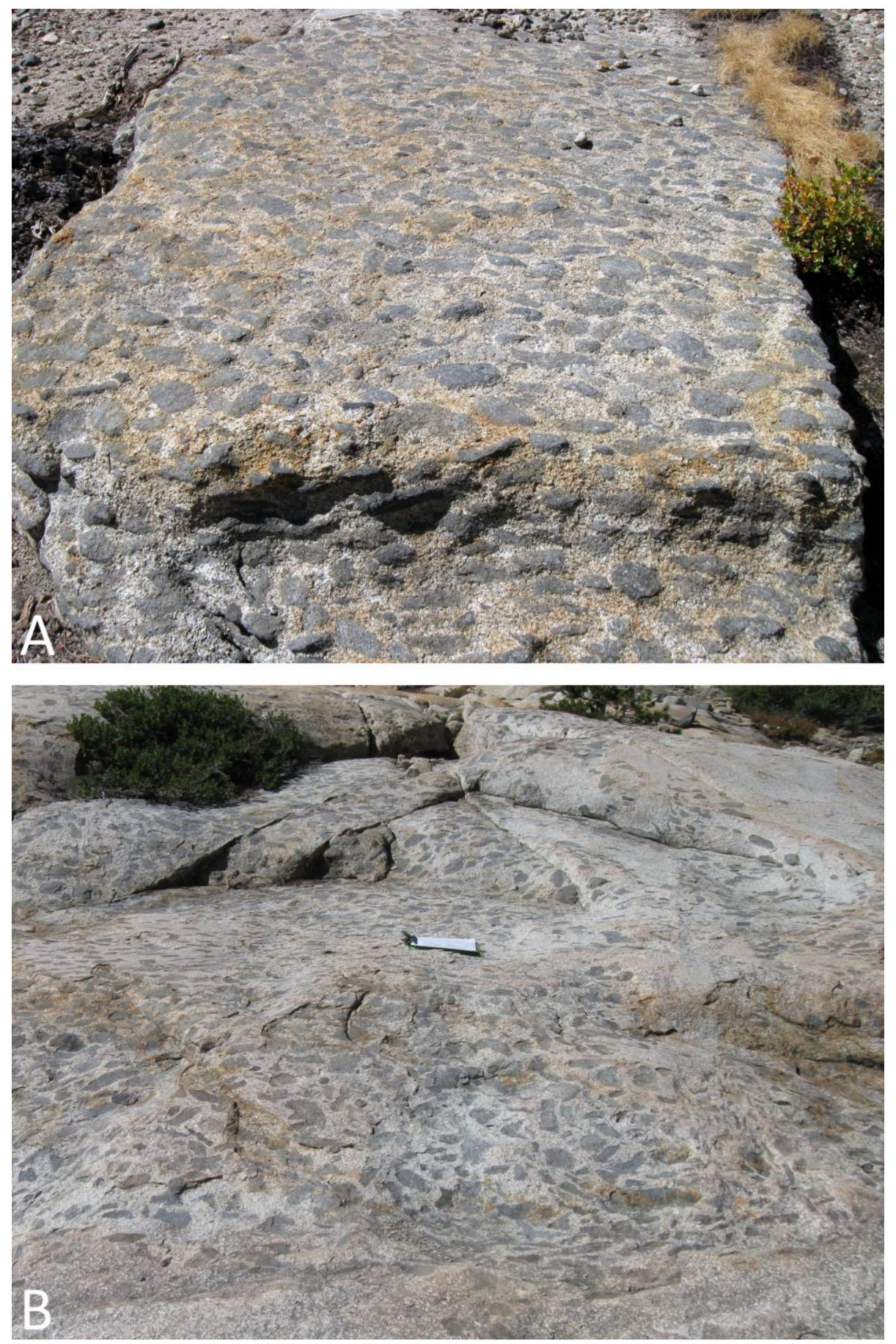

Figure 4. Enclave swarms within the Pyramid Peak granite. (A) Low-aspect-ratio enclaves in a tight swarm. Width of view is $\sim 2 \mathrm{~m}$. (B) Enclaves with higher aspect ratio. Note parallel alignment along the angular margin of the swarm. Clipboard length is 32 $\mathrm{cm}$. 

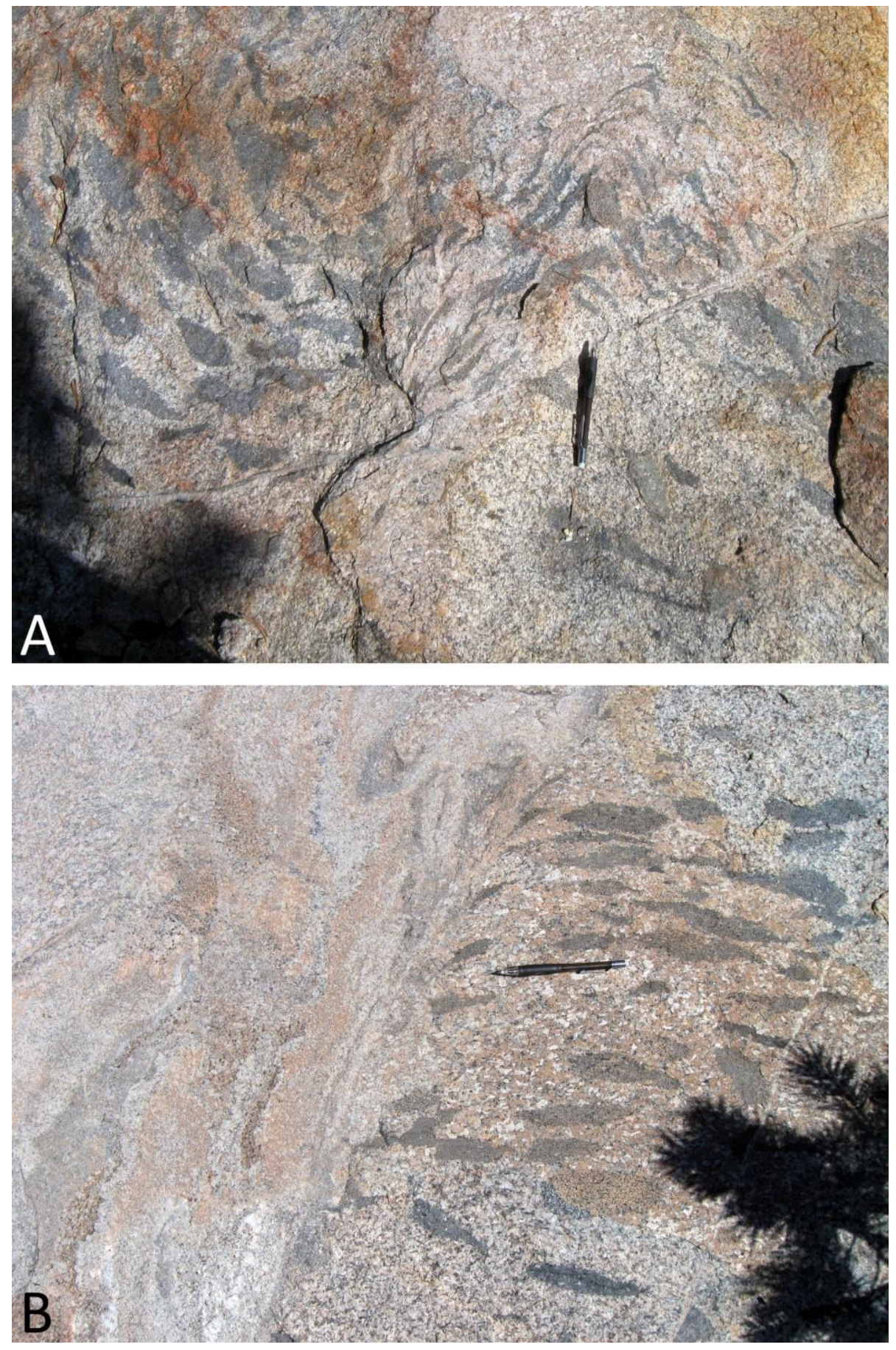

Figure 5. Features within Pyramid Peak granite enclave swarms. (A) Folding of channel of elongate enclaves. 14-cm pencil approximates position of axial surface. (B) Channel of elongate enclaves truncated by a pulse of magma, showing deflection of enclaves toward the photo bottom, analogous to a ductile shear zone. Same pencil as in A. 
into smaller bodies of widely variable size and shape by cross-cutting granitic veins and dikes. In places, the diorites have diffuse contacts with the surrounding granites, resulting in a large amount of heterogeneity amongst these diorites. These relations are inferred to record hybridization between felsic and mafic magmas.

Granitic pipes are uncommon in the diorite, but a small cluster of $\sim 10$ pipes is found in the vicinity of Maude Lake (Plate 1). These pipes range in diameter from 8 to $30 \mathrm{~cm}$ and plunge between 70 and $80^{\circ}$ to the east. Granitic pipes are inferred to form vertically as a more silicic magma rises buoyantly through a less silicic magma, and they are a useful indicator of paleohorizontal (Chapman and Rhodes, 1992; Wiebe and Collins, 1998). The orientation of these pipes indicates a modest $\left(10-20^{\circ}\right)$ rotation down to the west after pluton construction.

Textures and color indices of the diorite differ by outcrop, but the typical modes include fine-grained plagioclase (40-50\%), biotite (25\%), quartz (5-25\%), K-feldspar (5$10 \%)$, and hornblende $(<5 \%)$. Accessory minerals differ, but include sphene, hematite and other Fe-Ti oxides, as well as minor allanite and zircon, which reach up to $0.3 \mathrm{~mm}$ in length. Secondary epidote is present in minimal amounts. In some samples, the relatively high amount of quartz, which can comprise up to $25 \%$ of the mode, indicates that many of the rocks are not true diorites, but may represent dioritic magmas that mixed with granitic magmas (see below), resulting in quartz diorites and tonalites.

Xenoliths of the Sailor Canyon Formation along the contact in the northwestern part of the pluton range from sub-meter, irregularly shaped masses to larger, meter-scale 
bedded and unbedded, angular blocks. These are described further in the section on Intrusive Relationships.

\section{Desolation Valley Granodiorite}

The Desolation Valley granodiorite is a homogeneous, medium-grained pluton with a strong north-northwest-striking foliation. It has not been dated radiometrically, but it contains shear zones consistent with those deforming adjacent Jurassic plutons outside of the study area. These shear zones are absent in mid-Cretaceous plutons, implying a Jurassic or early Cretaceous age for the granodiorite (Loomis, 1993; Clay, 2014). The Desolation Valley granodiorite intrudes the Sailor Canyon Formation and is intruded by the Tyler Lake granodiorite. It is interpreted to be younger than the Pyramid Peak granite (Loomis, 1993), but the unpublished earliest Cretaceous age of the Pyramid Peak granite, described above, may reverse that interpretation. Only $0.3 \mathrm{~km}^{2}$ of the Desolation Valley granodiorite is exposed within the study area, and its relations with the major plutons of this study were not evaluated.

\section{Wrights Lake Granodiorite}

The Wrights Lake granodiorite comprises the western half of the study area. Loomis (1983) estimated that it covers as much as $\sim 775 \mathrm{~km}^{2}$. The pluton only intrudes the Pyramid Peak granite, but incorporates xenoliths of the Sailor Canyon Formation along part of its eastern margin.

The pluton is Cretaceous, but attempts by previous workers to obtain a specific age were inconclusive. Loomis (1983) reported a K-Ar biotite age of $106 \pm 2$ Ma on a sample $10 \mathrm{~km}$ south of the study area, which he considered "quite reliable." Earlier K-Ar 
dating by Evernden and Kistler (1970) from the same vicinity had yielded ages of 100 Ma by hornblende and 102 Ma by biotite on one sample, and 97.6 Ma by hornblende and 92.8 Ma by biotite on a second sample. Field relations show, however, that the Wrights Lake granodiorite intrudes the Lovers Leap granodiorite, which lies farther south and has a 93.7 Ma biotite age (Evernden and Kistler, 1970). Only the youngest date obtained for the Wrights Lake granodiorite is consistent with this field interpretation, so consistent ages for this and other adjacent plutons cannot be resolved without the use of higherprecision geochronological methods. An unpublished U-Pb zircon analysis (CA-IDTIMS) on a sample $2 \mathrm{~km}$ south of the study area gives an age of $106.383 \pm 0.040 \mathrm{Ma}$ (M. Eddy, written communication).

The medium-grained Wrights Lake granodiorite is largely homogeneous, although there are zones where it appears more mafic or felsic. The standard mode is $40-50 \%$ plagioclase, $20-30 \%$ quartz, $10-20 \%$ alkali feldspar, $10-15 \%$ biotite, and $\sim 1 \%$ hornblende. Quartz tends to be anhedral with weakly developed subgrains. The medium- to coarse-grained feldspars are mostly anhedral and less commonly subhedral. Medium-grained biotite defines two moderately developed, ubiquitous foliations, described in more detail below. Hornblende is subhedral. Fe-Ti oxides are abundant and sphene is common. Secondary epidote is also common and chloritization can be extensive, leaving only small remnants of biotite.

Typical color index is $10-15$, but in several localities, color index drops to as low as 1. These leucocratic rocks are fine-grained and composed of mostly quartz and feldspar. Biotite is well formed, but sparse, and commonly sub-millimeter in length with rare 
larger crystals up to $4 \mathrm{~mm}$. Most of the leucocratic areas are outcrop-scale and have discrete, non-planar boundaries. Some incorporate centimeter-scale, enclave-like blobs of the standard granodiorite. In one case, the lower-color-index material is well mingled with the surrounding standard granodiorite and forms complex lenses (Fig. 6).

In outcrops restricted to near the pluton margin, the color index increases to as high as 25. Biotite is common in these high-color-index areas and is less than $0.5 \mathrm{~mm}$ in length. Contacts are gradational. Throughout the pluton, mafic minerals accumulate into concentrations of various shapes and sizes, and schlieren are particularly common. The majority of mafic minerals are biotite, which form hexagonal sheets up to $3 \mathrm{~mm}$ in diameter. Hornblende is up to $1 \mathrm{~cm}$ in length. Schlieren are typically elongate parallel to one of the magmatic foliations, but form in a variety of shapes, including irregularly shaped "blobs" and arcuate bands. Schlieren differ in size, and are typically a few centimeters wide and $<0.5 \mathrm{~m}$ long. Some schlieren form larger, planar bands, the largest of which extends for over $30 \mathrm{~m}$ and has a thickness of $1 \mathrm{~m}$. Although schlieren are commonly isolated, some associate with aplite dikes up to $1 \mathrm{~m}$ thick, or leucocratic bodies within the granodiorite. The longer ones run parallel, or directly adjacent to, thicker, but equally long aplite bands. One 15-m-long, 2-cm-thick schlieren formation is bordered by a 12 -cm-thick aplite.

Other, less common types of biotite and hornblende concentrations include rounded, enclave-like clusters and amorphous bodies up to $1.8 \mathrm{~m}$ in diameter. Minerals are coarse as described for schlieren, and boundaries with the host granodiorite are sharp. The largest concentration is a mafic zone $6 \mathrm{~m}$ in length, which is cross-cut by a meter- 


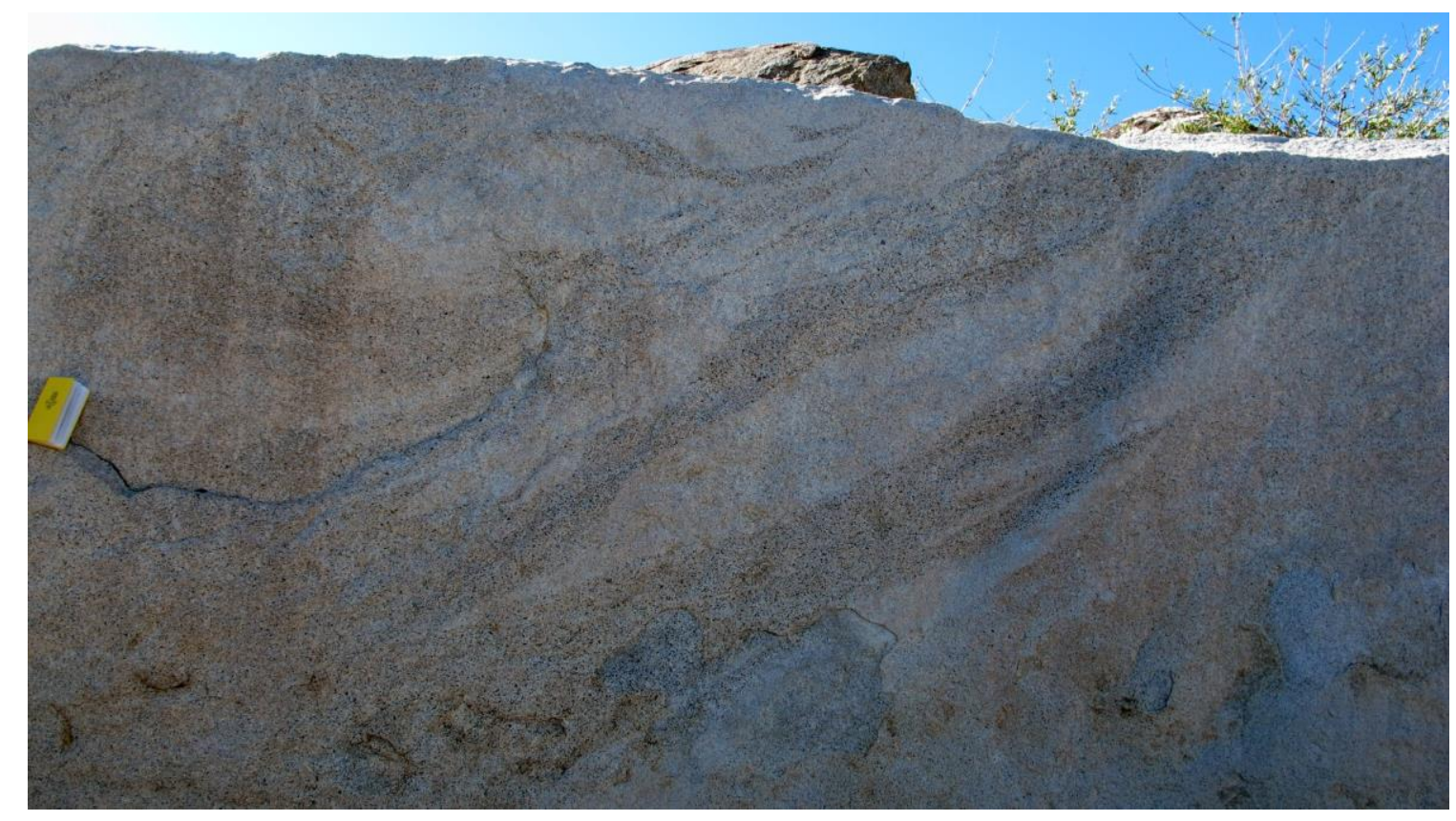

Figure 6. Mingling relationships between standard and leucocratic Wrights Lake granodiorite. Darker rocks are typical granodiorite. Leucocratic lenses interweave with granodiorite with discrete boundaries.

thick aplite dike. Crystal spacing varies within these concentrations, giving them a patchy coloration (Fig. 7).

Microgranitoid enclaves appear throughout the Wrights Lake granodiorite.

Hornblende and chloritized biotite give enclaves a typical color index of around 30.

Enclaves are commonly fine-grained and some have phenocrysts of anhedral plagioclase up to $0.8 \mathrm{~mm}$ in length and subhedral, rectangular hornblende up to $0.4 \mathrm{~mm}$ in length. Plagioclase is the dominant felsic mineral, and interstitial quartz is present in minimal quantities $(\sim 1 \%)$. The rest is hornblende, biotite, and anhedral sphene. There are pockets with high concentrations of sphene. Fe-Ti oxides are common and hematite is an accessory. 


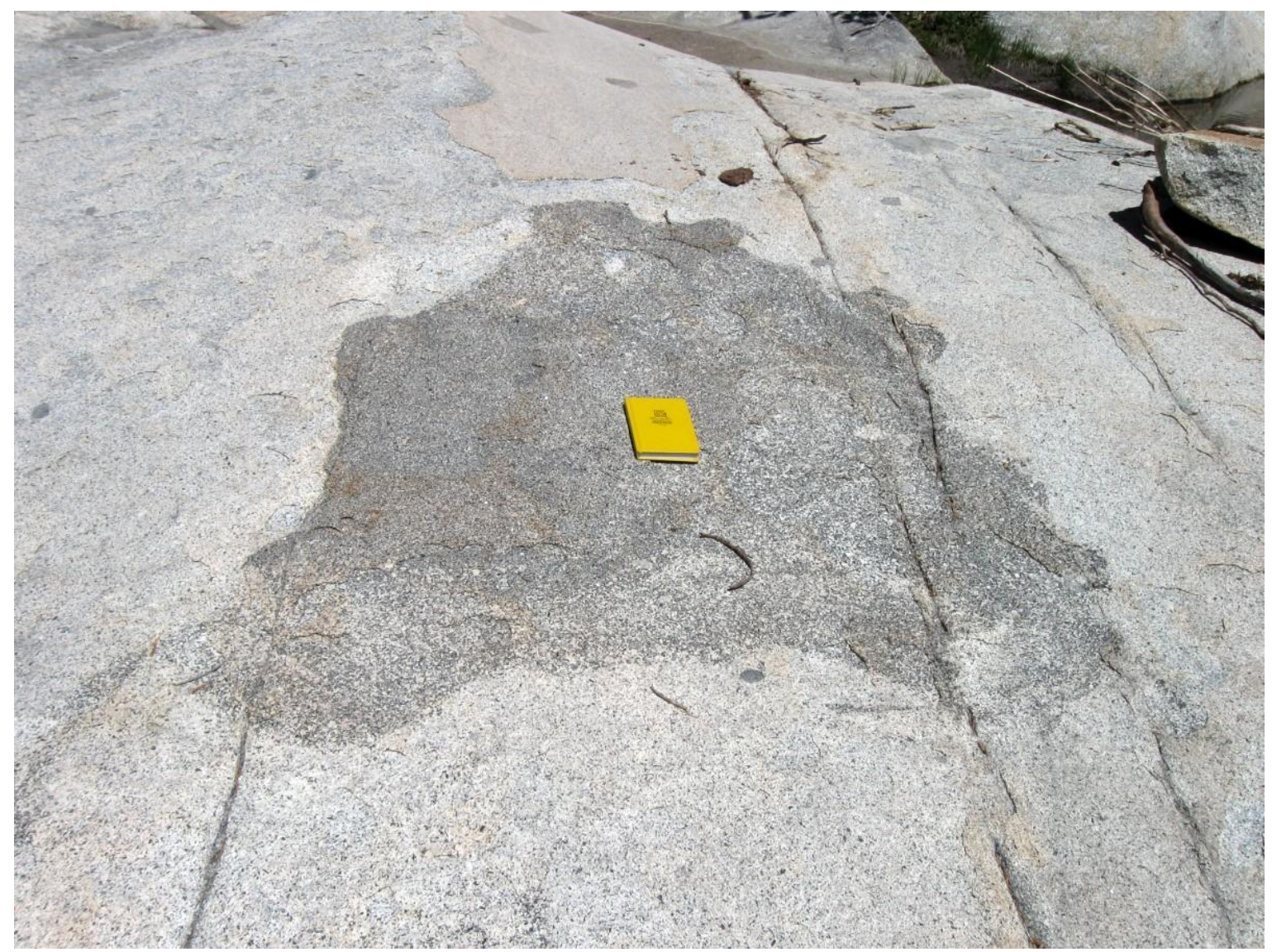

Figure 7. Amorphous 1.8-m-diameter schlieren "blob" in the Wrights Lake granodiorite. Note internal variations in color due to varying concentrations of biotite.

Enclaves are commonly isolated and range in size from 3 to $30 \mathrm{~cm}$, with typical aspect ratios from 1:1 to 3:1. The long axes of these enclaves generally show no preferred orientation. Spatial distribution varies by outcrop, but enclaves are present at all locations. One noteworthy aspect of these enclaves is that some are split and offset by $\geq 4 \mathrm{~cm}$, typically with no apparent continuation into the surrounding granodiorite. This suggests that small magmatic shear zones or magmatic faults may exist throughout the pluton, but are otherwise obscured without enclaves as markers (Fig. 8A, 8B). Enclave clusters also occur in which tens of enclaves rest in close proximity. Biotite and 

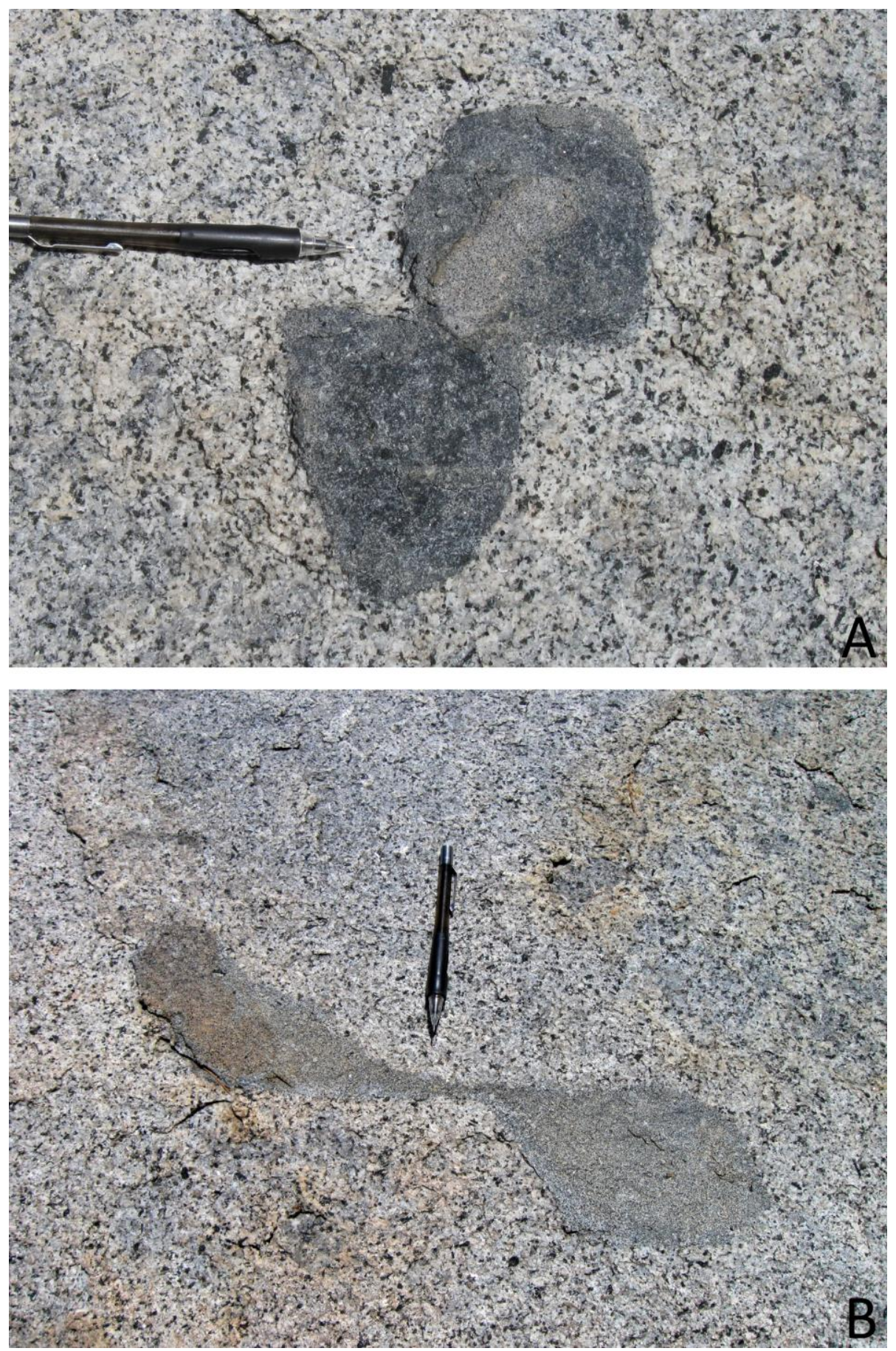

Figure 8. Offset microgranitoid enclaves in the Wrights Lake granodiorite. (A) Microgranitoid enclave displaying $4.5 \mathrm{~cm}$ of right-lateral-offset. Fault does not continue into the surrounding granodiorite, and is thus magmatic. (B) Enclave sheared with $15 \mathrm{~cm}$ of left-lateral-offset. Faint leucocratic bands extend along shear plane for several $\mathrm{cm}$ into the surrounding granodiorite (not apparent in photo). 
hornblende concentrate in the interstices (Fig. 9). The clusters are generally rounded bodies over $1.2 \mathrm{~m}$ in diameter. Larger enclave swarms are present in several places along the pluton margin. These swarms consist of hundreds of tightly packed enclaves with either no preferred orientation (Fig. 10A) or a planar alignment (flattened ellipsoids) parallel to the dominant foliation in the host (Fig. 10B).

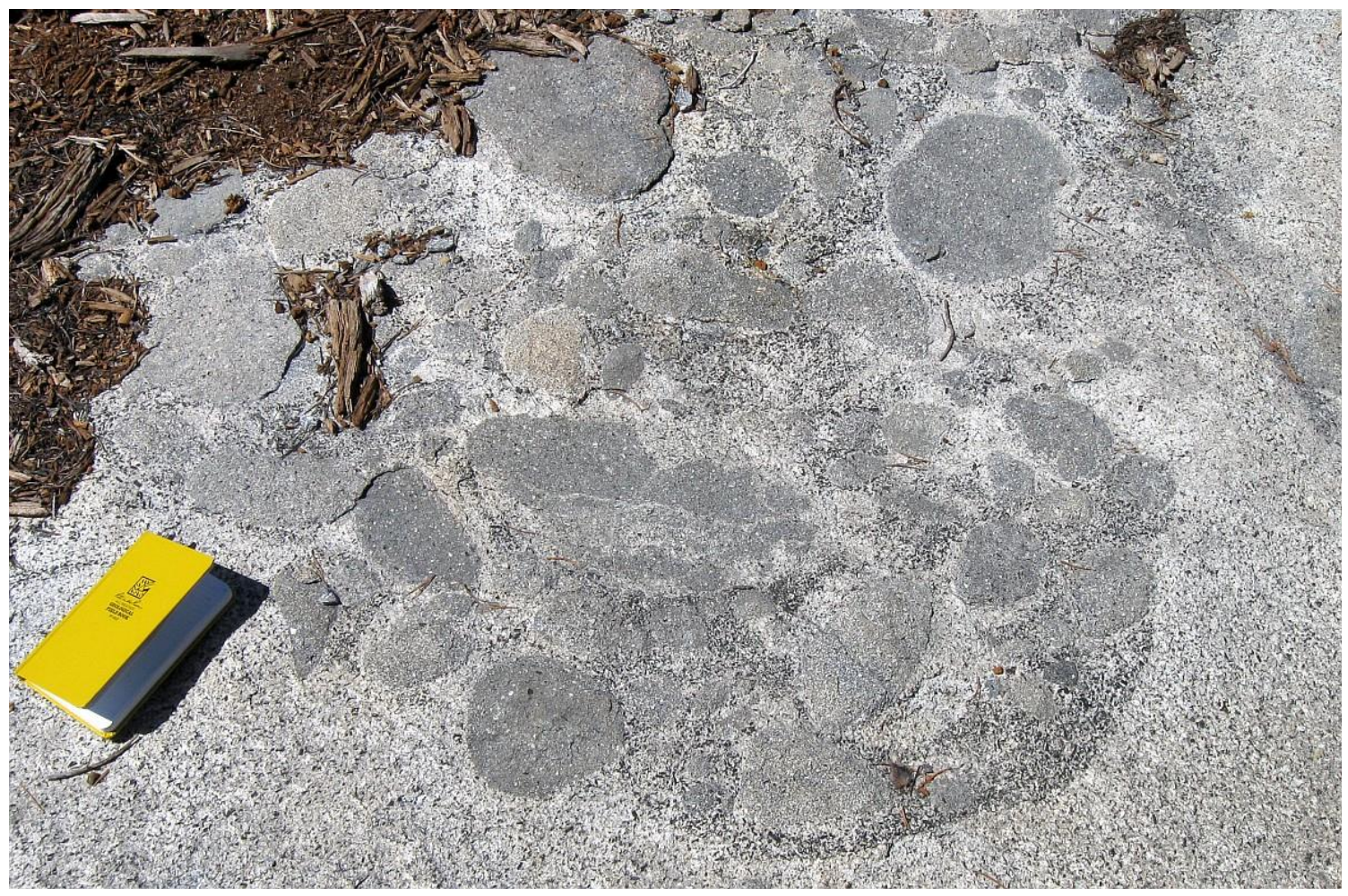

Figure 9. Cluster of rounded enclaves in the Wrights Lake granodiorite. Mafic minerals concentrate between enclaves and provide a "boundary" to the cluster. Some enclaves are surrounded by felsic rims. 

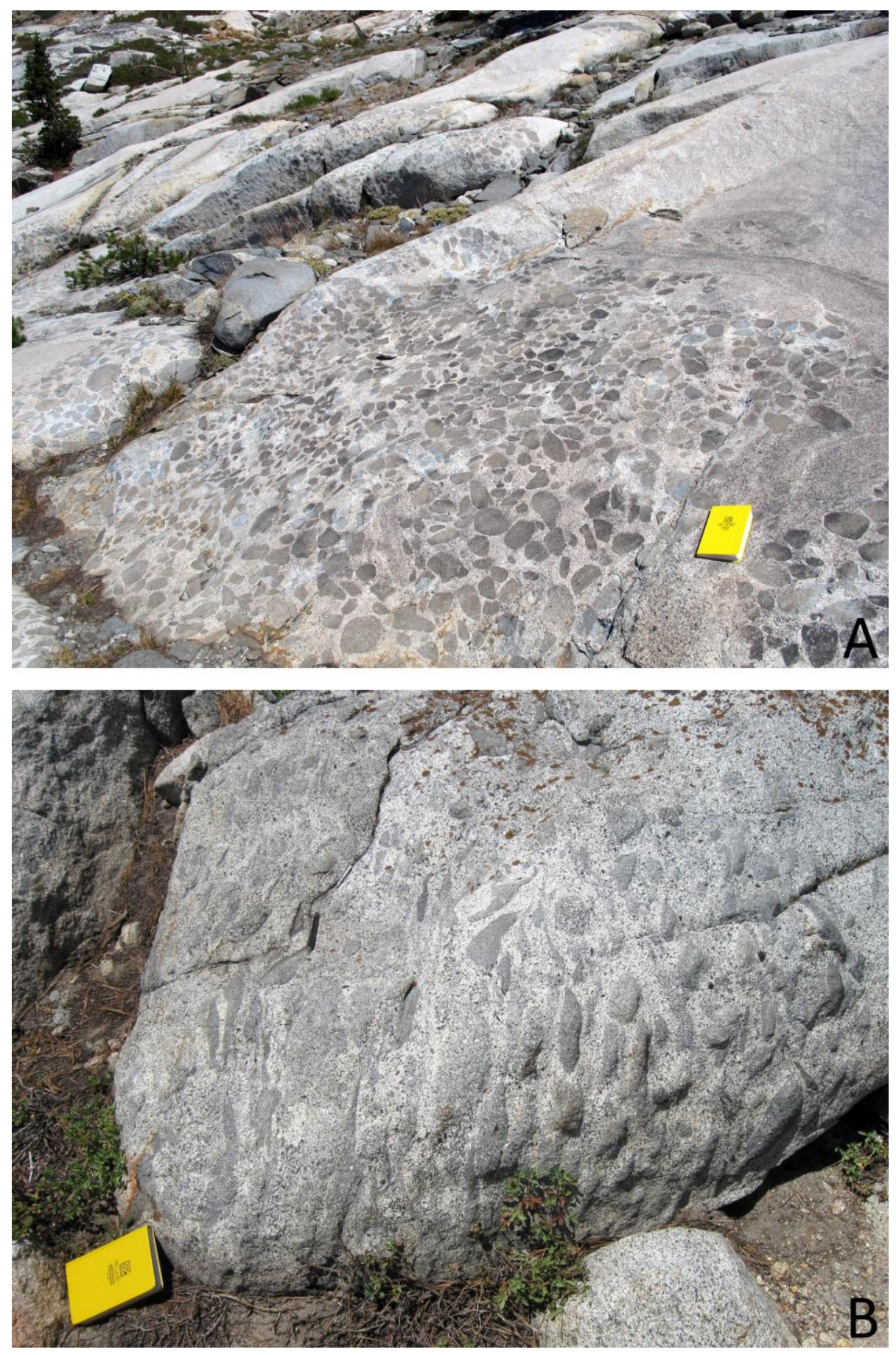

Figure 10. Enclave accumulations near the margin of the Wrights Lake granodiorite. (A) Swarm of low-aspect-ratio enclaves with no favored orientation. (B) Strong planar alignment of oblate enclaves parallel to the dominant magmatic foliation in host granodiorite. 
There are a few places where enclaves appear as parts of a larger overall feature.

Two syn-plutonic dikes document the intrusion of a second magma composition into the larger magma body. One dike is a non-planar channel of moderately packed, rounded, fist-sized enclaves with felsic auras and interstitial accumulations of schlieren. This dike is roughly $15 \mathrm{~m}$ long. A nearby 3-m-long dike is similar to the first, but with a wider diversity of enclave sizes, reaching up to $30 \mathrm{~cm}$ in length. Three-dimensional views of the second dike reveal that the enclaves are elongate roughly vertically, with a $\sim 2: 1$ aspect ratio, suggesting a steep flow direction (Fig. 11).

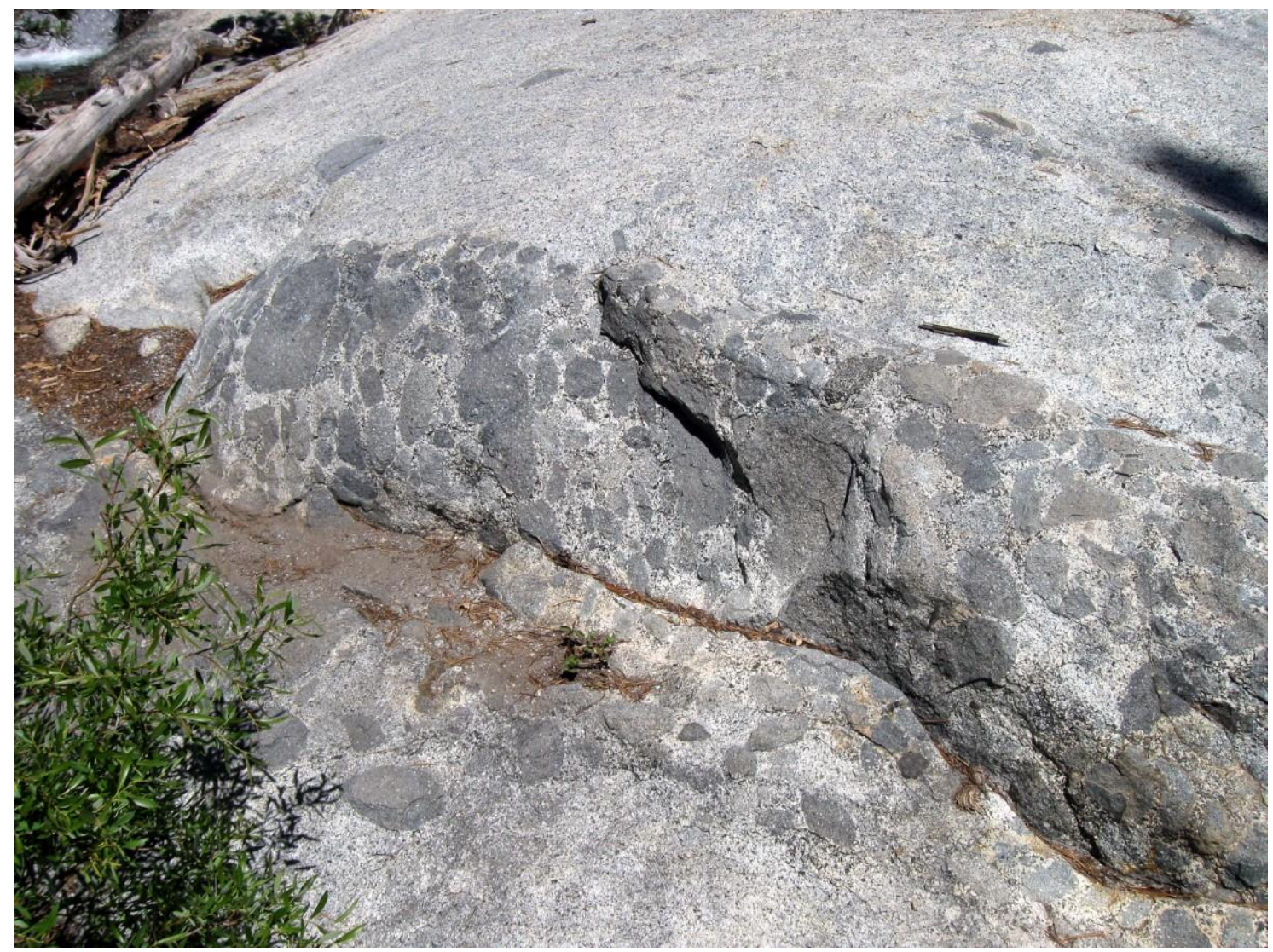

Figure 11. Syn-plutonic dike of enclaves in Wrights Lake granodiorite. Zone of enclaves on left shows alignment orthogonal to dike margins. $14 \mathrm{~cm}$ mechanical pencil for scale right of photo center is parallel to dike contact. Dike is roughly $2.5 \mathrm{~m}$ long. 
Xenoliths of the Sailor Canyon Formation and Pyramid Peak granite are found within $100 \mathrm{~m}$ of the margin of the Wrights Lake granodiorite. Angular blocks of Pyramid Peak granite are restricted to the southern half of the field area, and blocks of Sailor Canyon Formation are exposed in the north. Xenoliths are described in more detail in the section on Intrusive Relationships.

\section{Tyler Lake Granodiorite}

The $4 \mathrm{~km}^{2}$ Cretaceous Tyler Lake granodiorite makes up the majority of the southeastern corner of the study area (Fig. 2). It intrudes the Pyramid Peak granite, and is surrounded by the granite on its north, west, and south. On the east, the Tyler Lake granodiorite intrudes the Sailor Canyon Formation, a body of unnamed mafic rocks, and the Jurassic Desolation Valley granodiorite. The pluton has not been dated directly, but Sabine (1993) reported that $\mathrm{Rb} / \mathrm{Sr}$ data fall on a 106.8 Ma isochron established for the Bryan Meadow granodiorite, southeast of the study area.

The Tyler Lake granodiorite is a homogeneous, medium-grained, equigranular granodiorite to tonalite. It is leucocratic and has a color index of 5-15, but pervasively weathers a rusty orange, particularly at higher elevations. The pluton consists of subhedral to anhedral plagioclase $(60 \%)$, anhedral quartz $(\sim 30 \%)$, and anhedral perthitic microcline $(5 \%)$. Biotite $(5 \%)$ is the dominant mafic mineral and is typically finegrained. A zone at the southern margin features uncharacteristically coarse, 1-cm-long biotite sheets, and is the only recognized example of heterogeneity in the pluton. Biotite is extensively chloritized, and plagioclase cores are partially replaced by epidote and 
white mica. In the vicinity of hydrothermal pipes, described below, there is a higher degree of alteration. Accessory minerals include Fe-Ti oxides and rare sphene.

Mafic schlieren are sparse. The only significant accumulation of schlieren identified occurs within a $1 \mathrm{~m}$ radius of a hydrothermal pipe (see below), where the schlieren are arcuate and appear to wrap around the pipe. Microgranitoid enclaves are uncommon.

At least two felsic dikes intrude the Tyler Lake granodiorite. These dikes have a lower color index $(\sim 1)$ than the granodiorite and are mostly feldspar with very minor biotite. One 30-m-long dike is extensively cracked, and a series of fractures are oriented $40-50^{\circ}$ (counter-clockwise) from the dike margin. The dike is $0.2 \mathrm{~m}$ at its maximum thickness, tapering toward either end. These fractures are positioned every $4-6 \mathrm{~cm}$ along the length of the dike (Fig. 12). Overall, their orientation and spacing are compatible with en echelon tension fractures caused by left-lateral shear along the dike walls.

The Tyler Lake granodiorite is host to a large number $(>50)$ of hydrothermal pipes, concentrated around Gertrude and Tyler Lakes (Plate 1). The pipes consist of radially grown epidote crystals and a dark, aphanitic mineral in the core of a circular zone of quartz and feldspar pegmatite. Pipes are cylindrical and subvertical, and have diameters that generally range from $3-30 \mathrm{~cm}$ (Fig. 13). Similar pipes have been studied in the Tuolumne Intrusive Suite and Whitney Intrusive Suite, and are interpreted to record the escape of a volatile phase during the late stages of crystallization of shallow, silicic plutons (Mustart and Horrigan, 2008). 

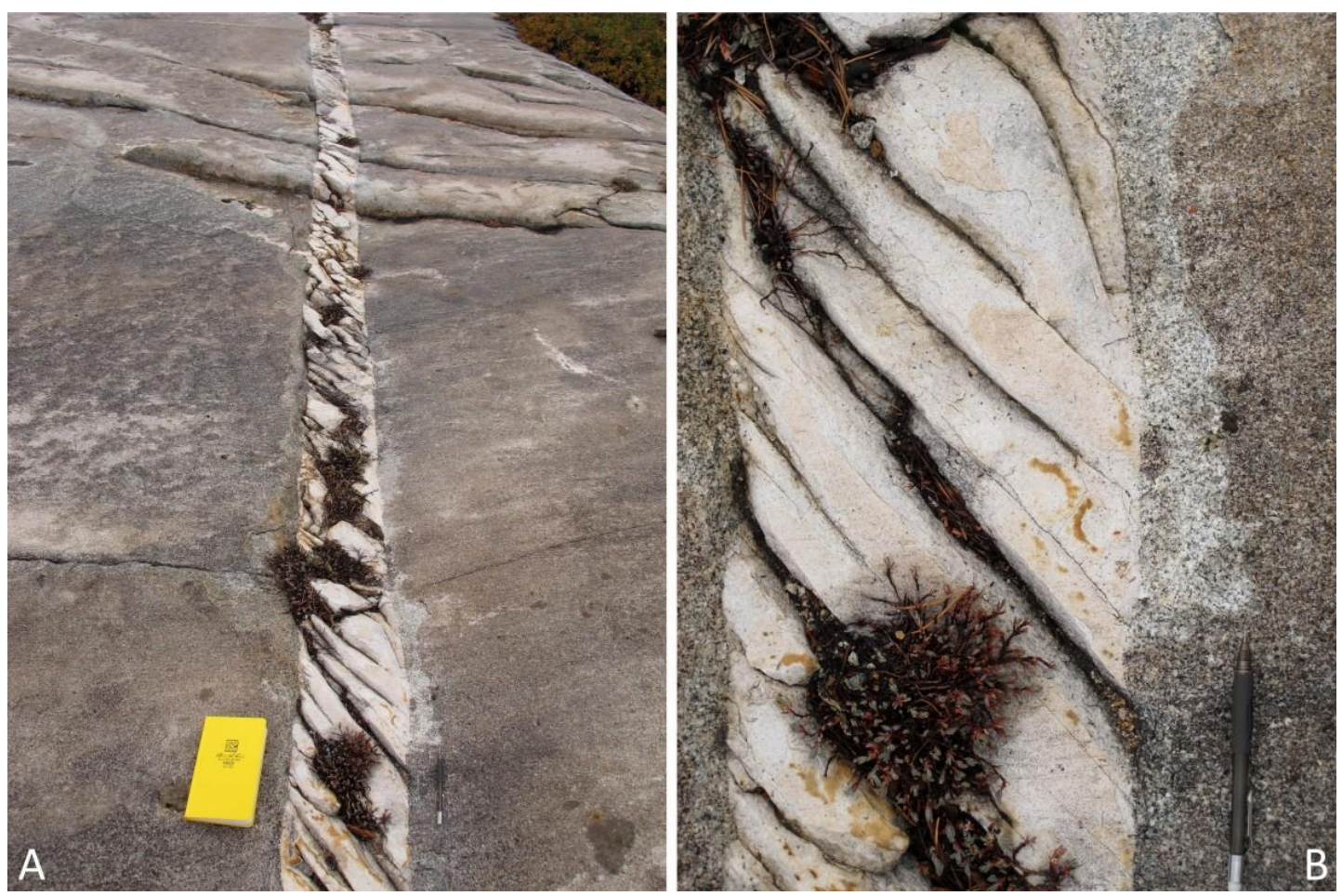

Figure 12. Felsic dike in Tyler Lake granodiorite. (A) Dike extends for $30 \mathrm{~m}$ with a maximum thickness of $0.2 \mathrm{~m}$. (B) Closeup view of dike, showing consistent angles of fracture. 

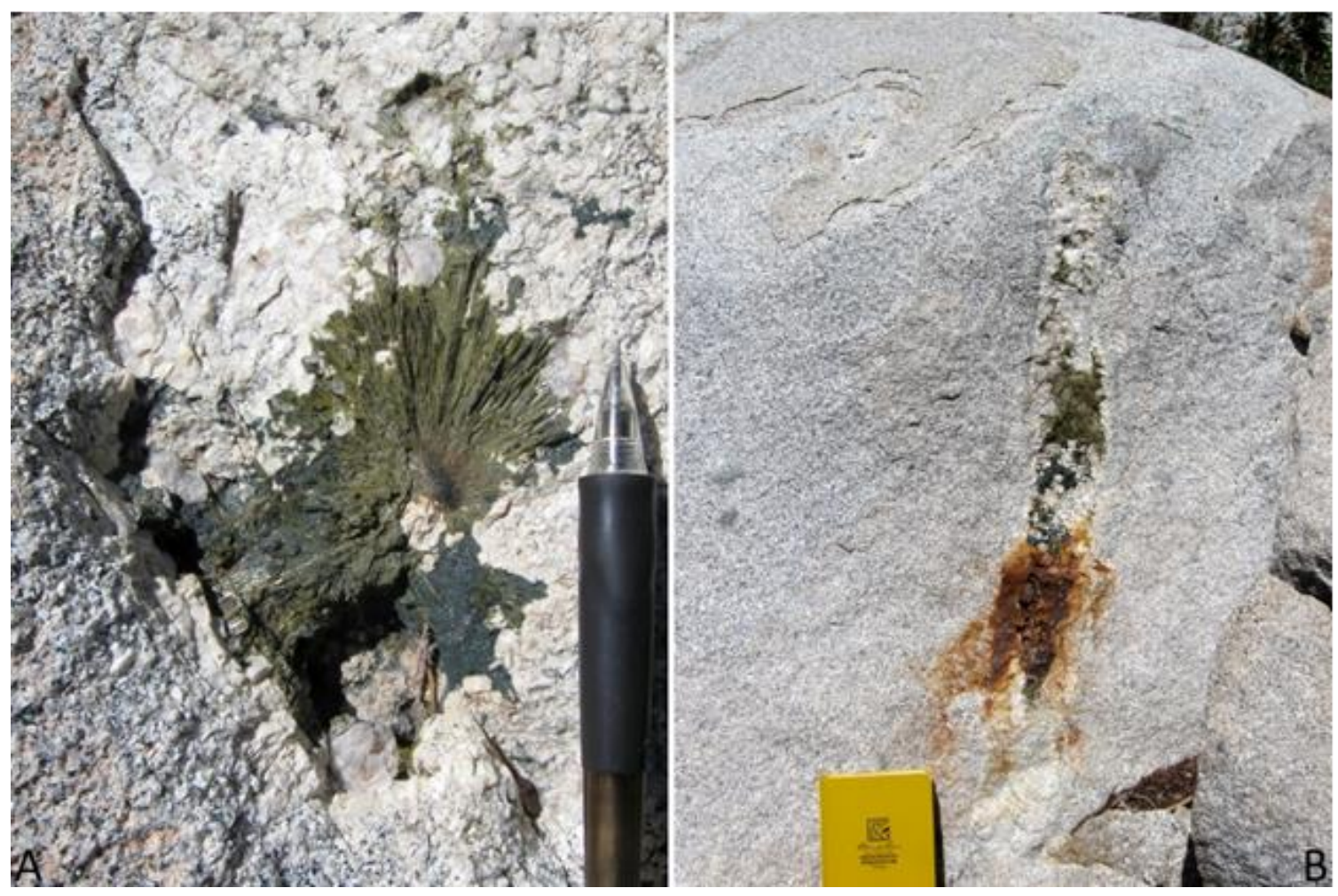

Figure 13. Hydrothermal pipes in the Tyler Lake granodiorite. (A) Typical exposure of hydrothermal pipe from a top view. (B) 80-cm-long cross-sectional view of pipe on a steep outcrop. 


\section{STRUCTURE}

Structures within the study area are discussed in the following section. These include folds of the host pendant and xenoliths, magmatic fabrics of the plutons, small shear zones within the plutons, and dikes.

\section{Folding of the Sailor Canyon Formation}

The Sailor Canyon Formation is folded in a regional, kilometer-scale anticline, with a north-northwest trending hinge line near the eastern border of the field area (Loomis, 1983). The rocks of this study are the western limb of the anticline. Beds strike an average of $148^{\circ}$ and dips average $\sim 48^{\circ} \mathrm{SW}$ (Fig. 14). To the east, bedding becomes less consistent due to local folding and faulting, as mapped by Fisher (1989). An unnamed Triassic limestone, which conformably underlies the Sailor Canyon Formation in the Mount Tallac pendant, is exposed just east of the study area near the mapped hinge.

Beds in the largest xenoliths and rafts of the Sailor Canyon Formation within the Pyramid Peak granite are gently folded. The folds have hinges that plunge moderately steeply west $\left(\sim 60^{\circ}\right)$ and have wavelengths of roughly $10 \mathrm{~m}$ and amplitudes of several $\mathrm{cm}$. The timing of these folds with respect to pluton emplacement is uncertain.

Folds in the host rock to the east are less consistent in style and orientation, and likely predate pluton emplacement. These open to tight folds plunge steeply $\left(60-70^{\circ}\right)$ to the north or south. The largest fold is a single, asymmetric, closed fold that has an amplitude of $>2 \mathrm{~m}$ and wavelength of $>1 \mathrm{~m}$. A nearby outcrop has a tight to isoclinal fold with a parasitic fold on one limb (Fig. 15). The style and orientation of folds are unique to each outcrop. Alluvial cover prevents the measurement of most wavelengths and amplitudes. 


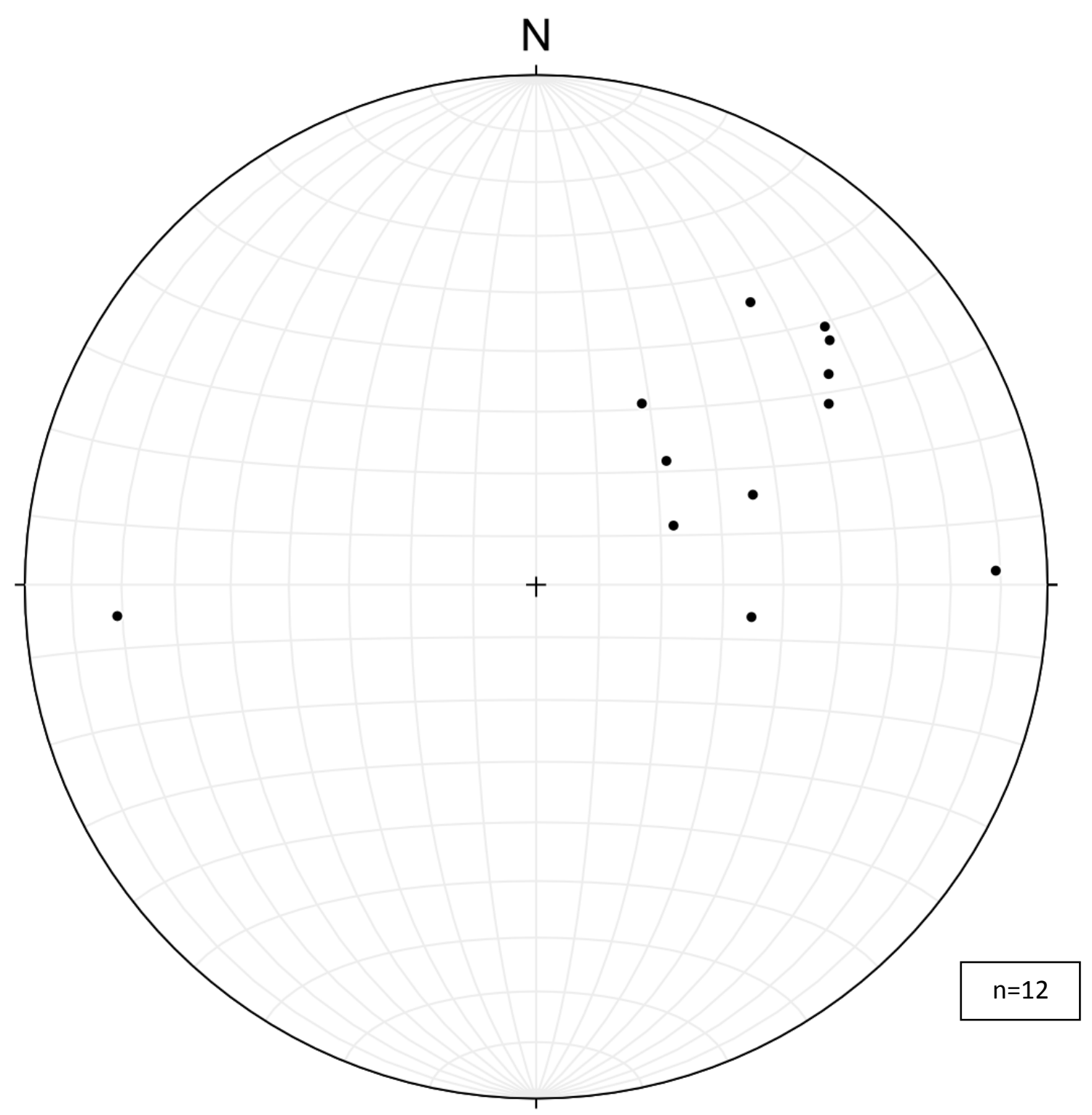

Figure 14. Poles to beds of the Sailor Canyon Formation. Bedding dips steeply to the southwest at almost all outcrops. All Stereonet data in this thesis are shown on equal area stereographic projections plotted using Stereonet 8.9.1 (Allmendinger et al., 2012; Cardozo and Allmendinger, 2013). 


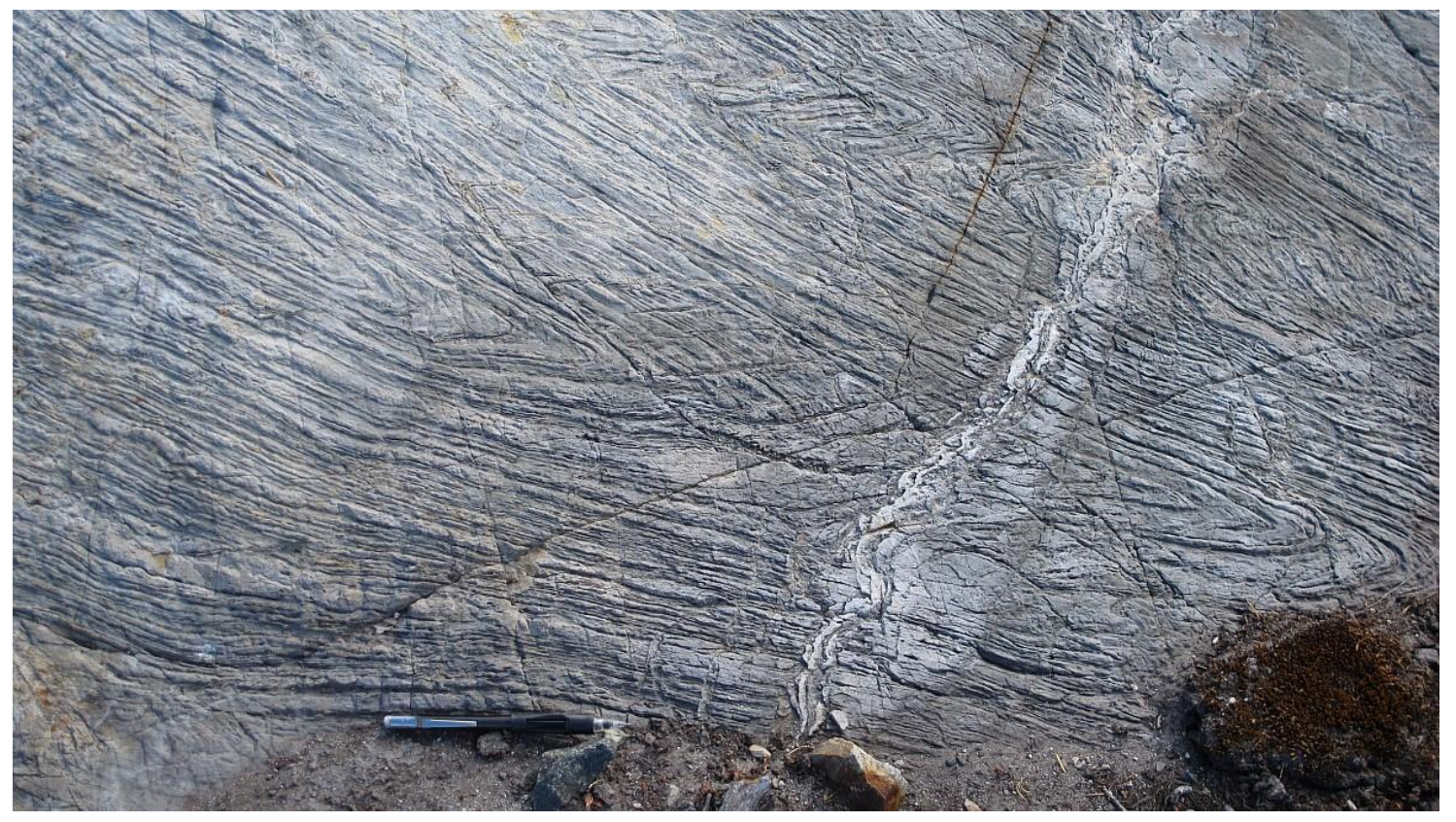

Figure 15. Tight to isoclinal folds within the Sailor Canyon Formation. A tight Z-fold is on the left (upper in photo) limb.

\section{Mineral Fabric Patterns}

The Pyramid Peak granite has a weak to moderate magmatic foliation exhibited by coarse-grained K-feldspar and local fine-grained biotite. The fabric can be difficult to discern due to the low color index of the pluton and may be absent in some outcrops. Foliation orientation is fairly consistent throughout the pluton, and average strike is $162^{\circ}$, coincident with the long dimension of the pluton (Fig. 16). Foliations typically dip between $60^{\circ}$ and $89^{\circ}$, to both the northeast and southwest, but dip angles are as low as 49 $9^{\circ}$ Fabrics locally strike east-west, and may represent complexities that were not evident in the field. Although data are few $(n=7)$, weak lineations plunge moderately to the southwest, averaging $51^{\circ}$. Foliations within the diorite are uncommon, regardless of fabric intensity in the surrounding granite. Where recognizable, the diorite fabric is 


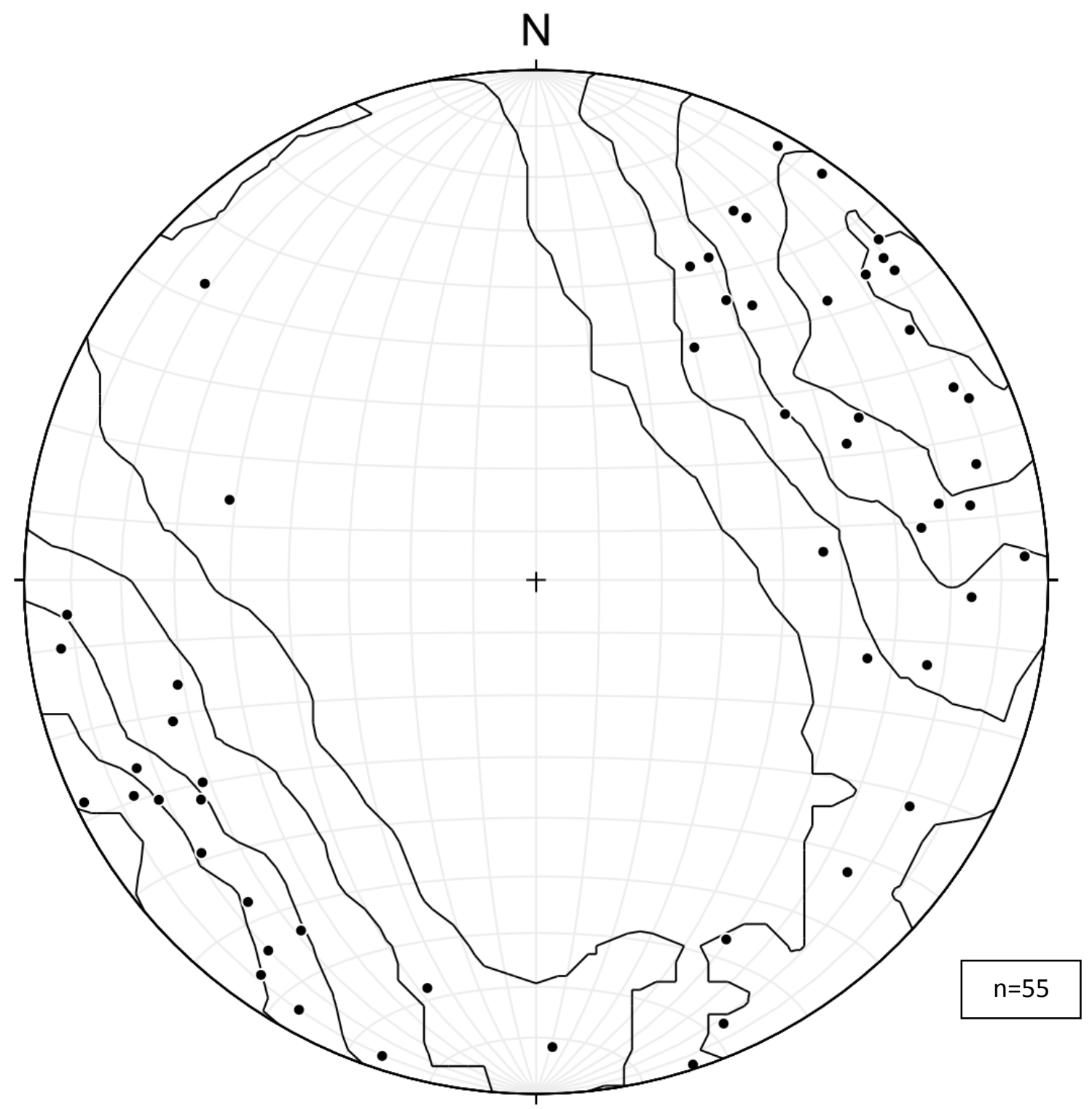

Figure 16. Poles of foliations within the Pyramid Peak granite. Foliations are steep and have a dominant northwest strike. All contoured Stereonet data in this thesis have a contour interval of 2 sigma using the method of Kamb (1959). 
roughly concordant with that of the granite. Foliation in the granite does not deflect or intensify around diorite bodies. There is also no appreciable increase in fabric intensity near the pluton margins.

The Pyramid Peak granite contains a >100-m-wide domain of solid-state foliation near Maude Lake (Plate 1). This foliation has an average strike of $149^{\circ}$, and typically dips steeply $\left(\sim 79^{\circ}\right)$ to the southwest. A well-exposed vertical section shows that foliation is locally gently folded, and dips can decline to as low as $30^{\circ}$ southwest. Lineations are steep $\left(\sim 66^{\circ}\right)$ and plunge south. Fabric intensity varies. The higher strain subdomains are defined by quartz ribbons and anhedral, elliptical K-feldspars (Fig. 17). Subdomains of moderate foliation intensity have weakly elongated quartz and fractured feldspars. Aplites also contain elongate quartz. Uncommon kinematic indicators of sigmoidal Kfeldspar porphyroclasts show normal, southwest-side-down shear. Enclaves within the solid-state domain are highly elongate parallel to the foliation, and have aspect ratios of up to $15: 1$, except near the edges of the domain, where enclaves have no preferred alignment. Diorites within the solid-state domain contain small folds of foliation in their margins that have wavelengths of $3 \mathrm{~cm}$ and amplitudes of $10 \mathrm{~cm}$. The limbs of these folds align parallel to foliation. The solid-state fabric domain is abruptly truncated to the east at a high angle by granite containing the prevailing magmatic foliation. Other local areas of solid-state fabric are described in the section on ductile shear zones. 

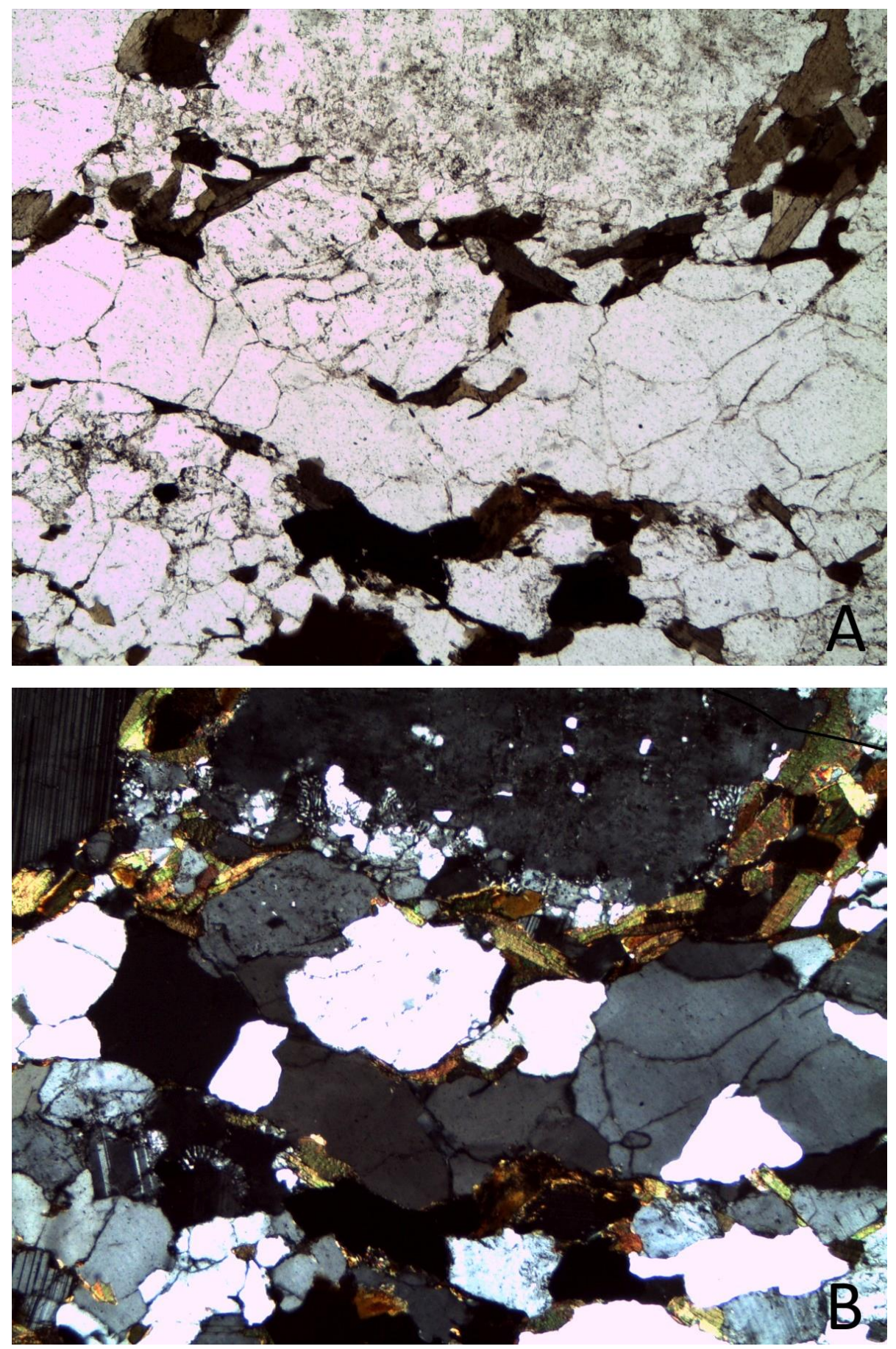

Figure 17. Photomicrographs of solid-state deformation in Pyramid Peak granite of Maude Lake. Quartz ribbon runs horizontally through center in (A) plane polar and (B) cross polar light. Horizontal field of view is $3 \mathrm{~mm}$. 
The Wrights Lake granodiorite has two distinct magmatic foliations, which typically overprint each other (Fig. 18). Foliations are easily recognized by moderate to strong alignments of medium-grained biotite. One foliation strikes roughly east-west, discordant to the pluton margin. Dips are steep and generally exceed $60^{\circ}$ to the north or south. This fabric is better observed away from the margin. The other foliation is generally margin-parallel and mirrors bends in the pluton margin. This foliation also dips steeply, and exceeds $60^{\circ}$ to the east or west. This pattern becomes less clear farther from the margin. Outcrops typically contain both fabrics, and one fabric is invariably stronger in intensity. Lineations are uncommon and plunge steeply.

The Tyler Lake granodiorite has a very weak foliation, which does not show an obvious pattern (Fig. 19). The foliation is defined by fine-grained biotite, but because of the weakness of the fabric, there is significant uncertainty in the measurements. Lineations have not been identified.

\section{Shear Zones}

Ductile shear zones are scarce overall, but a number are found near the center of the Pyramid Peak granite (Fig. 20). Shear zones tend to strike northwest and dip steeply toward the northeast. Lineations are steep where measureable. Kinematic data are few, but there are examples of both northeast-side-up (reverse sense) and southwest-side-up (normal sense) displacement. In one outcrop of intermixed granite and diorite, numerous short, steep, 1-cm-thick ductile shear zones have normal offsets of $\sim 6 \mathrm{~cm}$. 


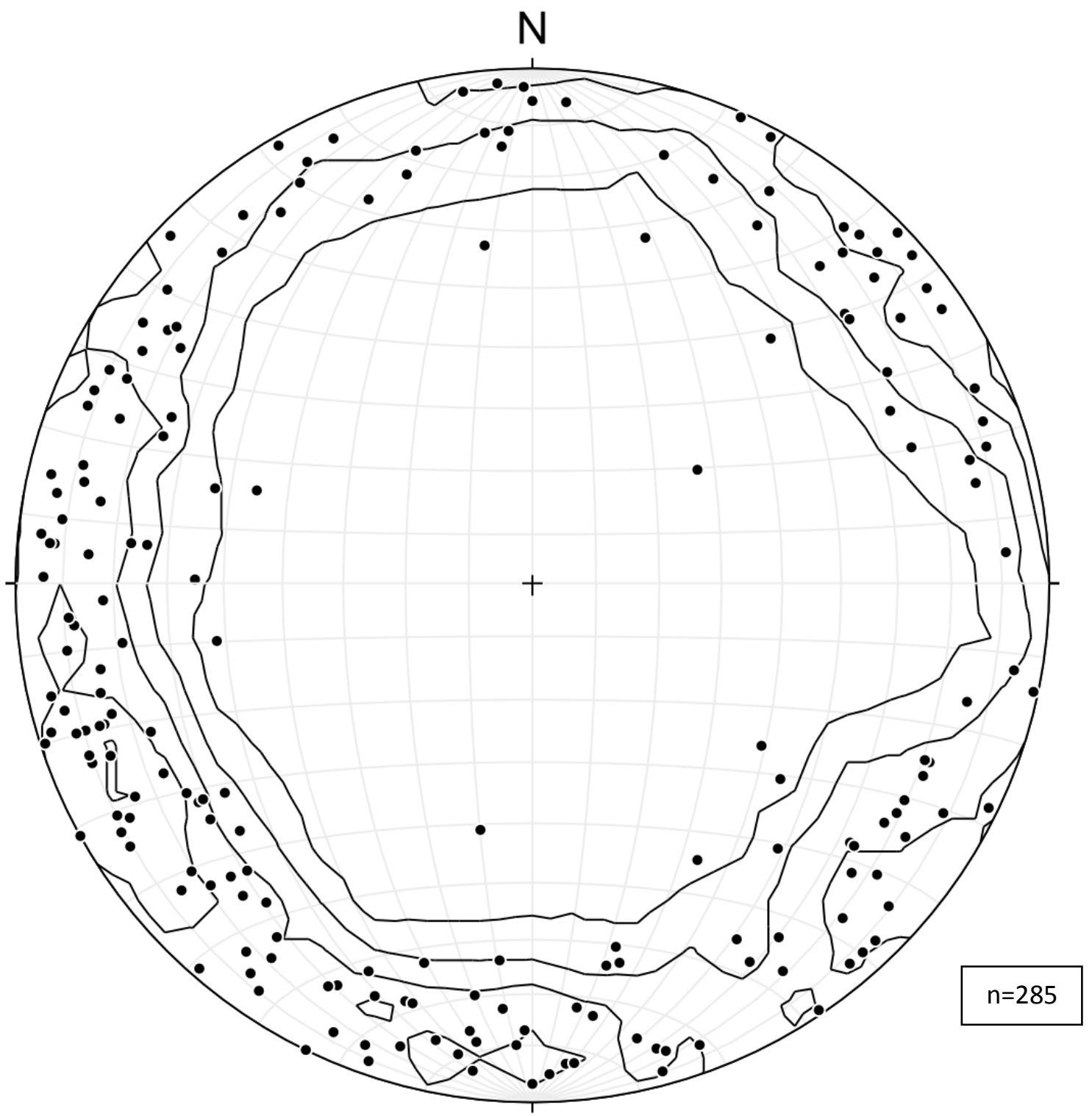

Figure 18. Poles of foliations within the Wrights Lake granodiorite. Foliations are steep. Mapped data (Plate 1) show an east-west population and a north-south population, which are not easily distinguished by stereographic projection. 


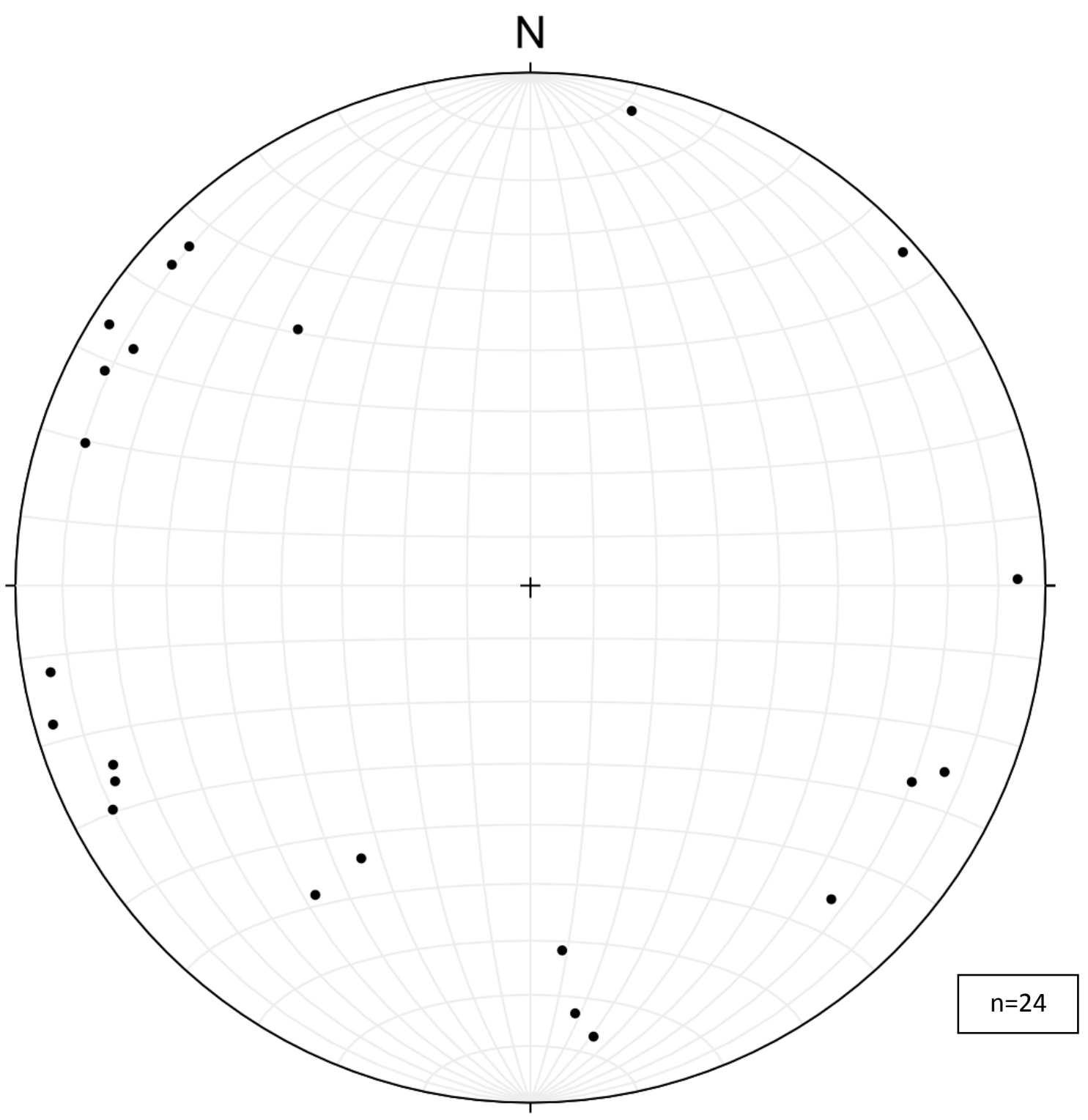

Figure 19. Poles of foliations within the Tyler Lake granodiorite. Foliations are steep, but have no strongly preferred orientation. 


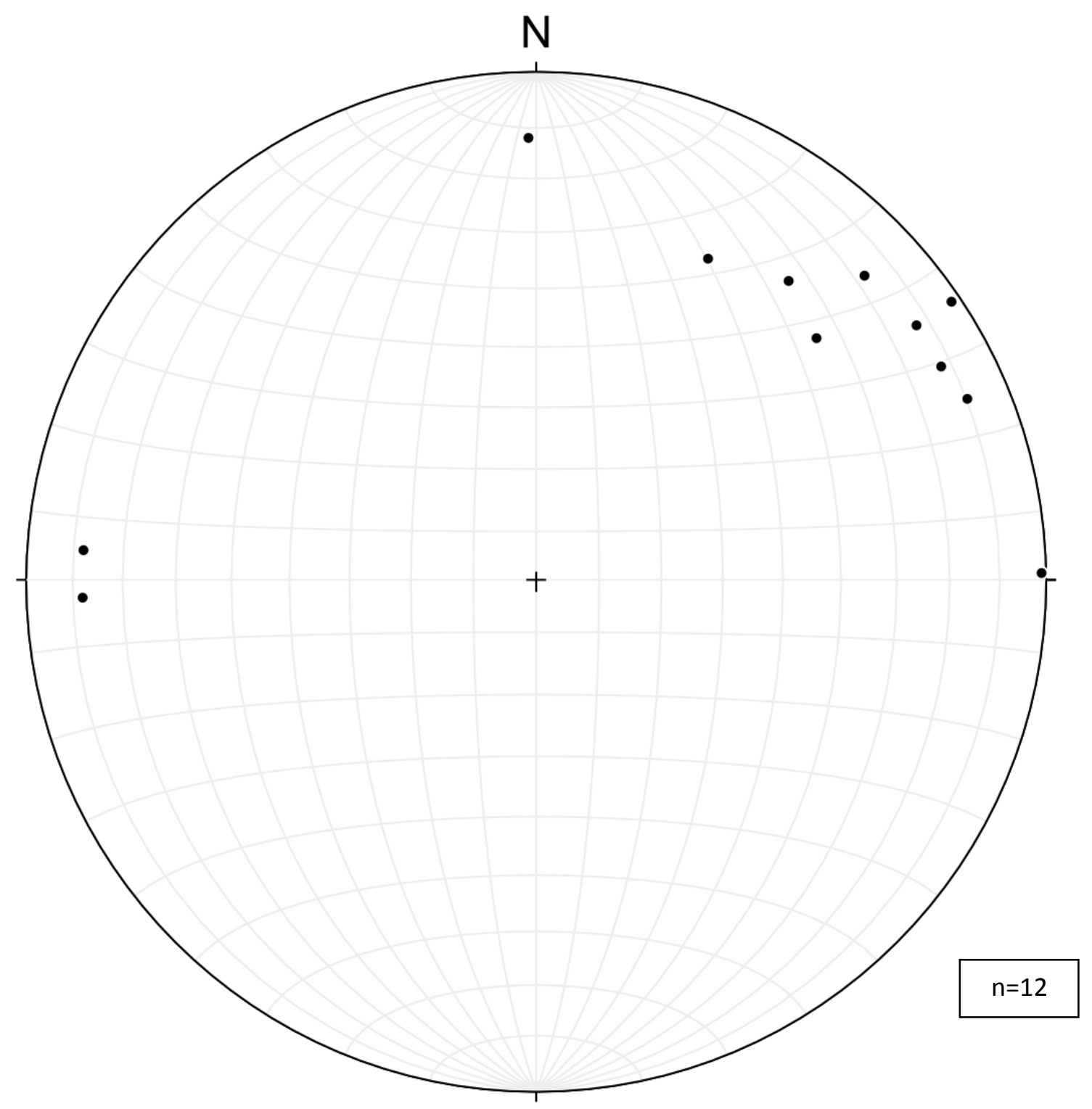

Figure 20. Poles to shear zones within the Pyramid Peak granite. 
A 50-cm-thick mylonite zone of Pyramid Peak granite within a diorite body strikes southeast $\left(124^{\circ}\right)$ and dips $\sim 56^{\circ}$ to the southwest. Asymmetric sigma and delta porphyroclasts of K-feldspar indicate a southwest-side-down, normal offset. This mylonite zone does not extend into the adjacent diorites.

The Wrights Lake granodiorite does not contain any large, through-going shear zones, but numerous offsets of enclaves indicate thin, 1-2-cm-thick shear zones (Fig. 8B). In most places, shear planes cannot be traced into the surrounding granodiorite. These offsets are generally $\geq 4 \mathrm{~cm}$ in length, and are both sinistral and dextral. One wellexposed sheared enclave is offset $\sim 10 \mathrm{~cm}$ by a steep, northwest-striking shear zone with normal and dextral separation.

\section{Dikes}

Several fine-grained mafic dikes intrude the Pyramid Peak granite. The longest is $<30 \mathrm{~m}$, and thicknesses reach up to $2 \mathrm{~m}$. The dikes intrude both the granite and the diorite. They are steeply dipping and have a dominant east-west trend, although outliers exist (Fig. 21).

Three short ( $\leq 3.5 \mathrm{~m}$ long) mafic dikes in close proximity to each other cut across the Pyramid Peak granite contact with the Wrights Lake granodiorite at right angles, extending equal distances into both plutons (Fig. 22A, 22B). Thicknesses of these dikes reach up to $0.8 \mathrm{~m}$. These dikes are fine-grained and have a color index of 40-50. These are the only mafic dikes that intrude the Wrights Lake granodiorite within the study area, aside from the syn-plutonic dikes described above (Fig. 11). 


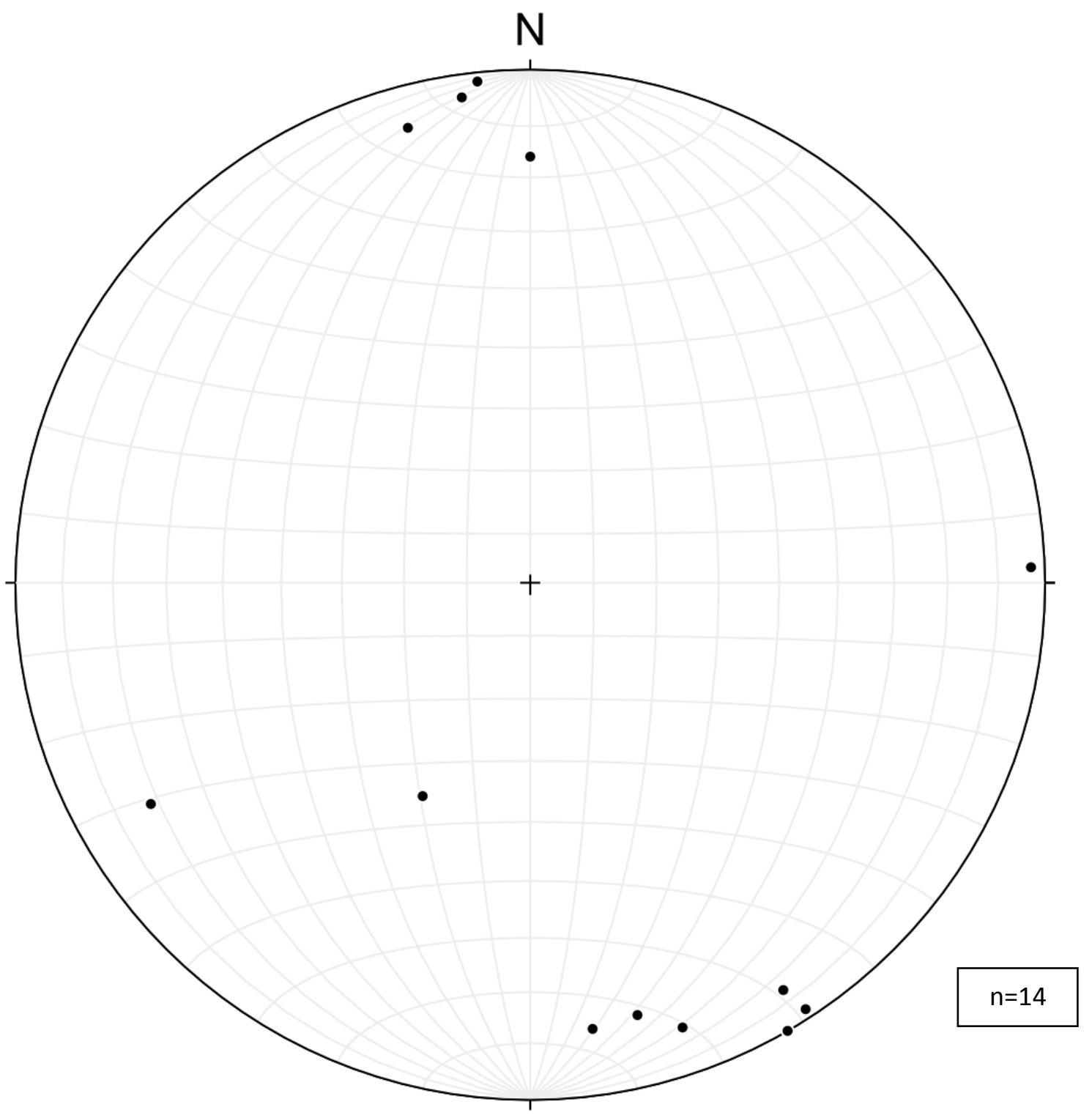

Figure 21. Poles to mafic dikes in the Pyramid Peak granite. 

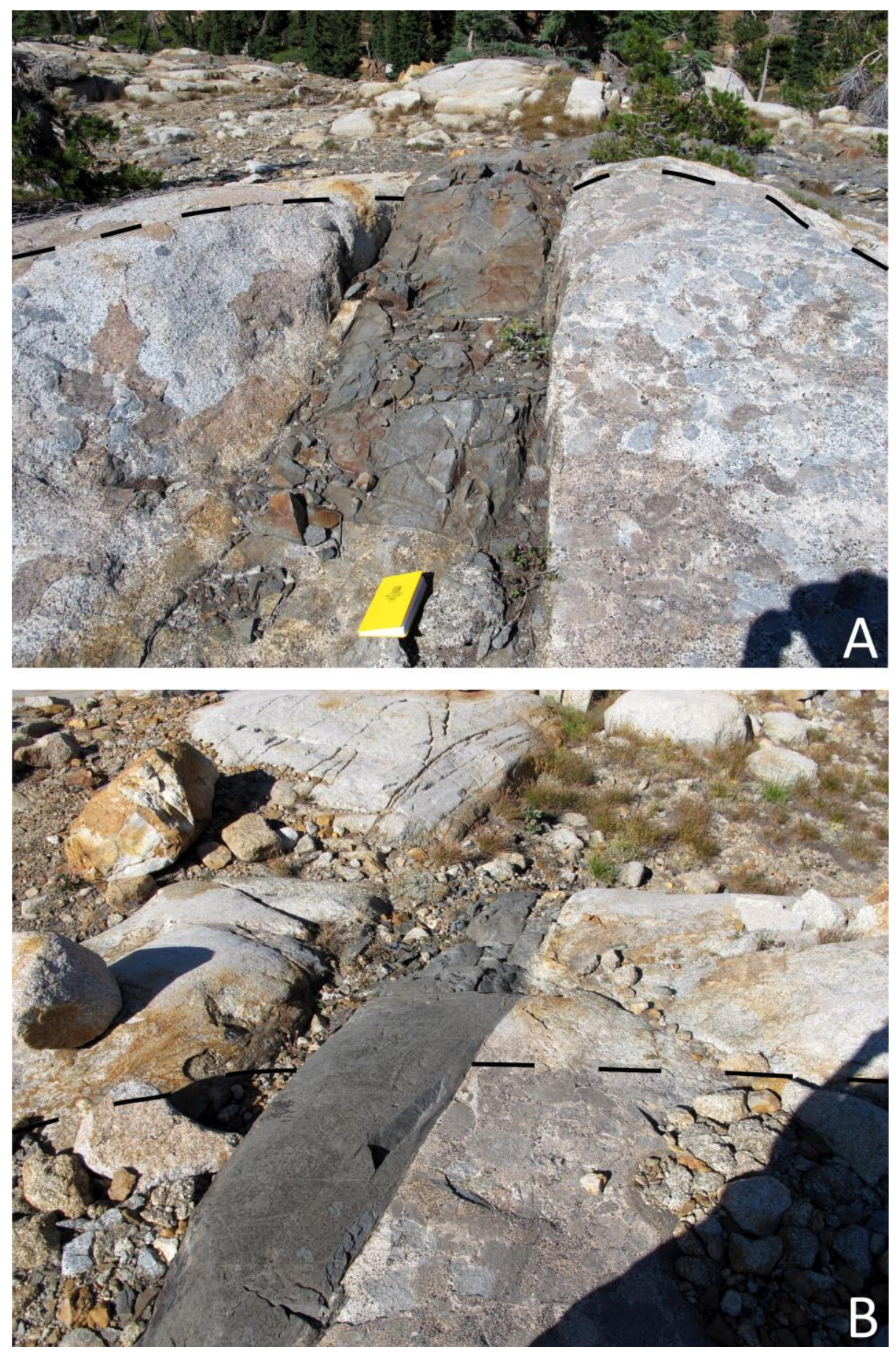

Figure 22. Short mafic dikes crossing the contact of the Wrights Lake granodiorite and Pyramid Peak granite. Contact between granite (top) and granodiorite (bottom) is marked by dashed line. (A) Dike has a total length of $3.5 \mathrm{~m}$ and thickness of $\sim 0.8 \mathrm{~m}$. Yellow field book is $19 \mathrm{~cm}$ long. (B) Top view of a second dike. Thickness is $\sim 0.5 \mathrm{~m}$. 
In contrast, aplite dikes are ubiquitous in the Wrights Lake granodiorite. They are typically $\leq 20 \mathrm{~cm}$ in thickness and extend for up to tens of meters. Some taper down to points and pick up again less than $50 \mathrm{~cm}$ away. Some dikes cross-cut other aplite dikes and microgranitoid enclaves, and a few of those features are offset by several centimeters across the dikes (Fig. 23). These offsets may reflect oblique opening of the dike, or intrusion along a magmatic fault. Aplite dikes are less prevalent in the Pyramid Peak granite and Tyler Lake granodiorite.

Dikes of Wrights Lake granodiorite rarely intrude the Pyramid Peak granite. One granodiorite dike intrudes a large xenolith of the Sailor Canyon Formation, roughly 100 $\mathrm{m}$ from the main contact (Plate 1 ). This schlieren-rich, $30 \mathrm{~m}$ by $1.5 \mathrm{~m}$ dike is bound by the xenolith on two sides and does not intrude into the diorite of the Pyramid Peak pluton on the ends, perhaps indicating it is part of an older, unidentified granodiorite, and not the Wrights Lake granodiorite. Elsewhere, two granodiorite dikes, approximately $13 \mathrm{~m}$ by $1.5 \mathrm{~m}$, intrude Pyramid Peak diorite and have sharp, angular boundaries (Plate 1). None of these dikes are connected to the Wrights Lake granodiorite at the exposure level.

There is a single medium-grained granite dike intruding the Wrights Lake granodiorite that has a color index of $\sim 5$. It grades into a fine-grained leucocratic rock with a color index of $\sim 1$. The dike extends at least $30 \mathrm{~m}$, has a maximum thickness of 1 $\mathrm{m}$, and tapers down to $0.3 \mathrm{~m}$ where the exposure ends. Boundaries are sharp and planar. The dike is predominantly fine-grained quartz ( $\sim 50 \%$ ), and contains $\sim 35 \%$ plagioclase and $\sim 15 \%$ microcline. Medium- to coarse-grained hornblende is sparse. Chloritized biotite, allanite, sphene, Fe-Ti oxides, and secondary epidote are minor constituents. 


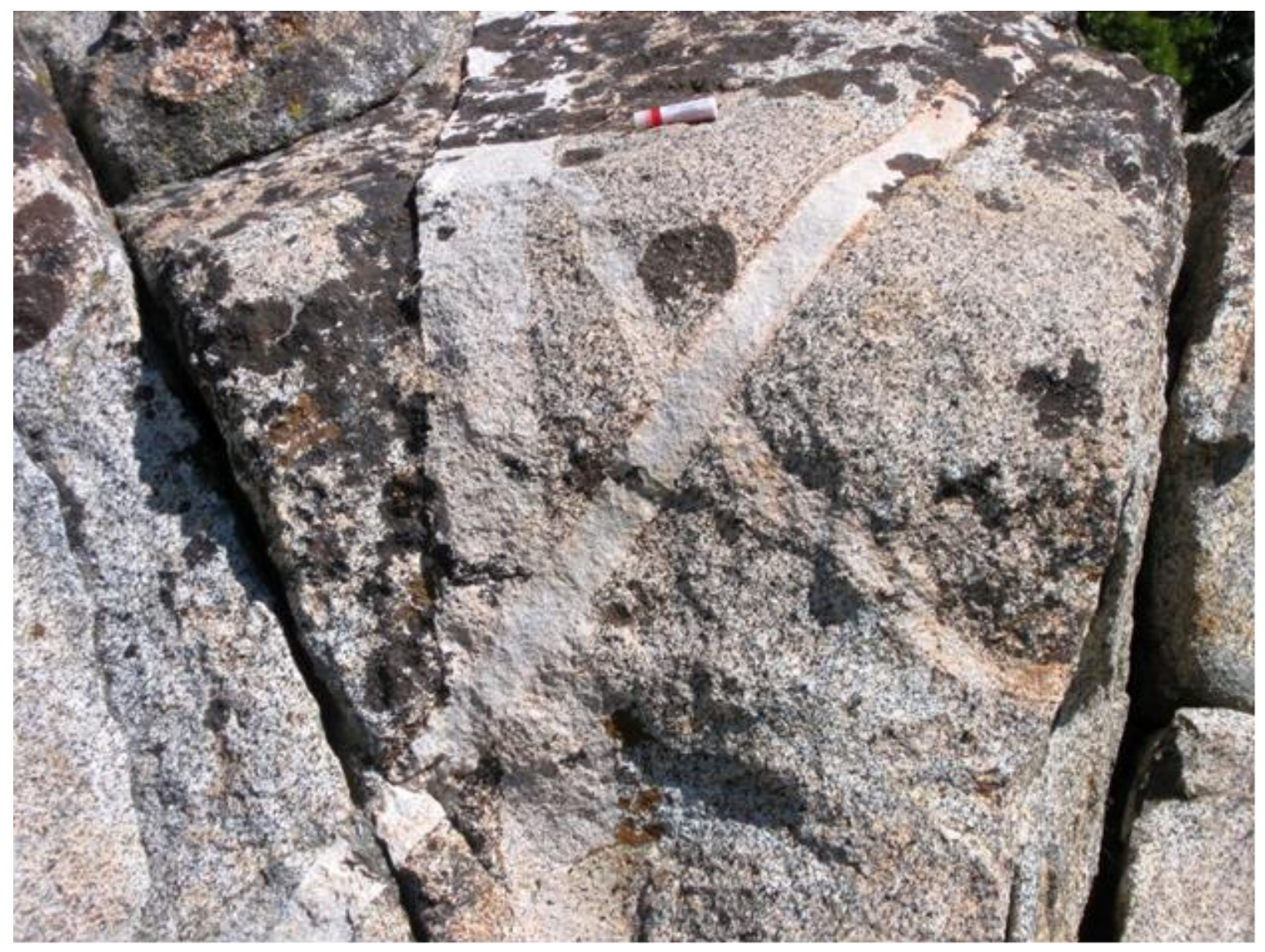

Figure 23. Vertical face of Wrights Lake granodiorite intruded by aplite dikes. Dike oriented diagonally toward top right cross-cuts two earlier dikes with normal separation of $\sim 2 \mathrm{~cm}$. Lip balm container approximately $6.5 \mathrm{~cm}$. 


\section{INTRUSIVE RELATIONSHIPS}

The contacts of the three plutons are addressed in the following section, described in order of age of intrusion. The main contact between the Pyramid Peak granite and Wrights Lake granodiorite trends roughly N-S and spans the entire field area for $\sim 6 \mathrm{~km}$. For ease of description, the "northern area" of the Pyramid Peak-Wrights Lake contact is defined as the segment from Top Lake to the northern border of the study area (Plate 1). In this segment, both plutons intrude the Sailor Canyon Formation.

\section{Pyramid Peak Granite - Sailor Canyon Formation Contact}

The Pyramid Peak pluton makes up the majority of the eastern half of the study area. The Wrights Lake granodiorite intrudes the entire western side of the Pyramid Peak pluton, and other plutons intrude to the north, south, and southeast, leaving the original extent of the Pyramid Peak pluton unknown. The only remaining contacts between the Pyramid Peak granite and the host Sailor Canyon Formation are in poorly exposed parts of the study area (Saucedo, 2005). Aside from the main contact, xenoliths and rafts of the Sailor Canyon Formation appear in two areas within the Pyramid Peak pluton.

In the northern area, xenoliths of the Sailor Canyon Formation are common and are easily recognized by their tendency to weather a rusty color, which in some places colors the surrounding granite. At some outcrops, xenoliths are irregularly shaped, unbedded masses and have no apparent alignment of their long axes. These xenoliths generally range from 3-30 cm in length (Fig. 24). Meter-scale xenoliths occur locally.

Other outcrops contain xenoliths that are elongated, tapering blocks that align with a consistent orientation (Fig. 25). These xenoliths have aspect ratios of up to 7:1 and 


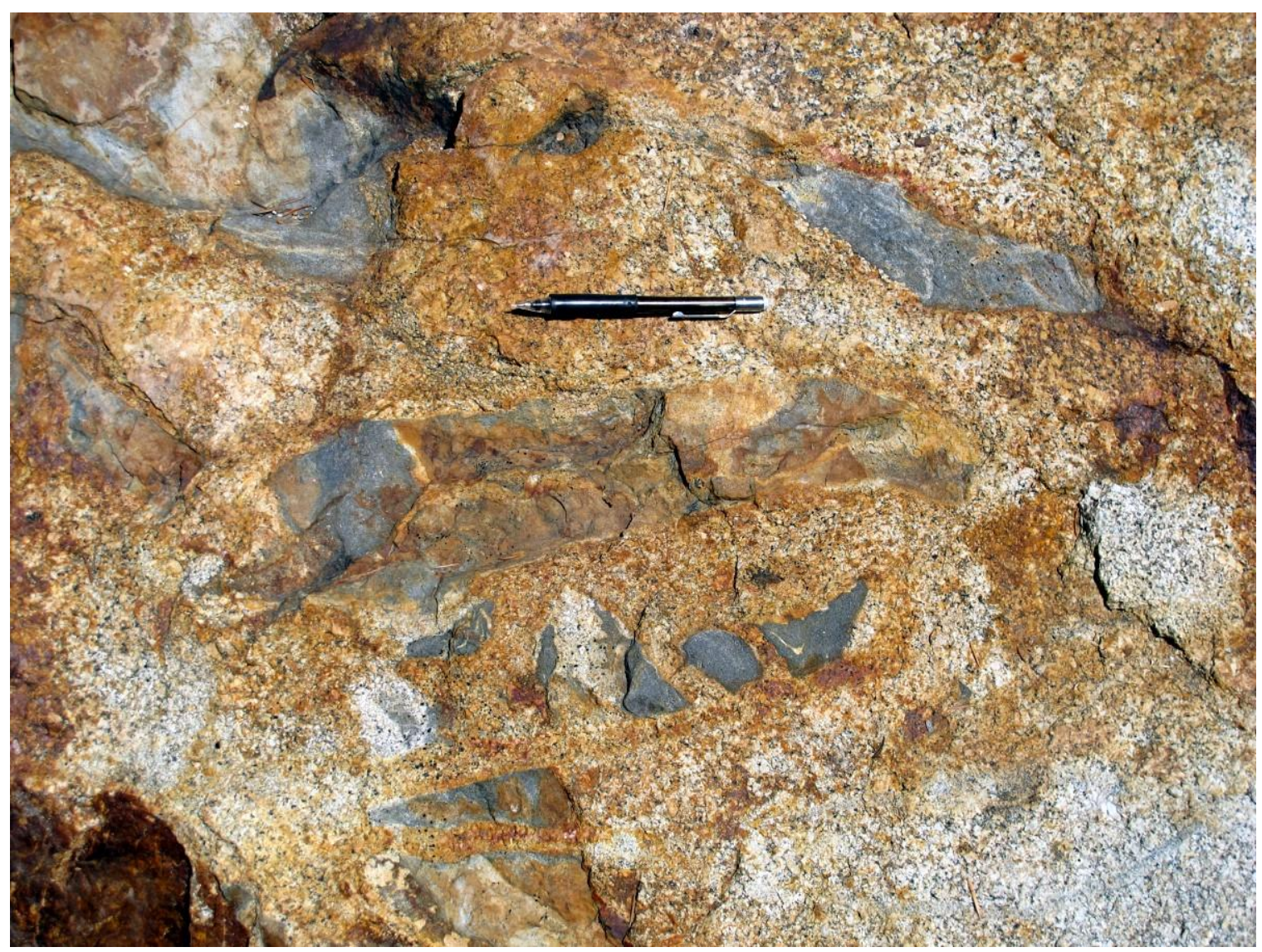

Figure 24. Small, unbedded, angular xenoliths of Sailor Canyon Formation in the Pyramid Peak granite. 


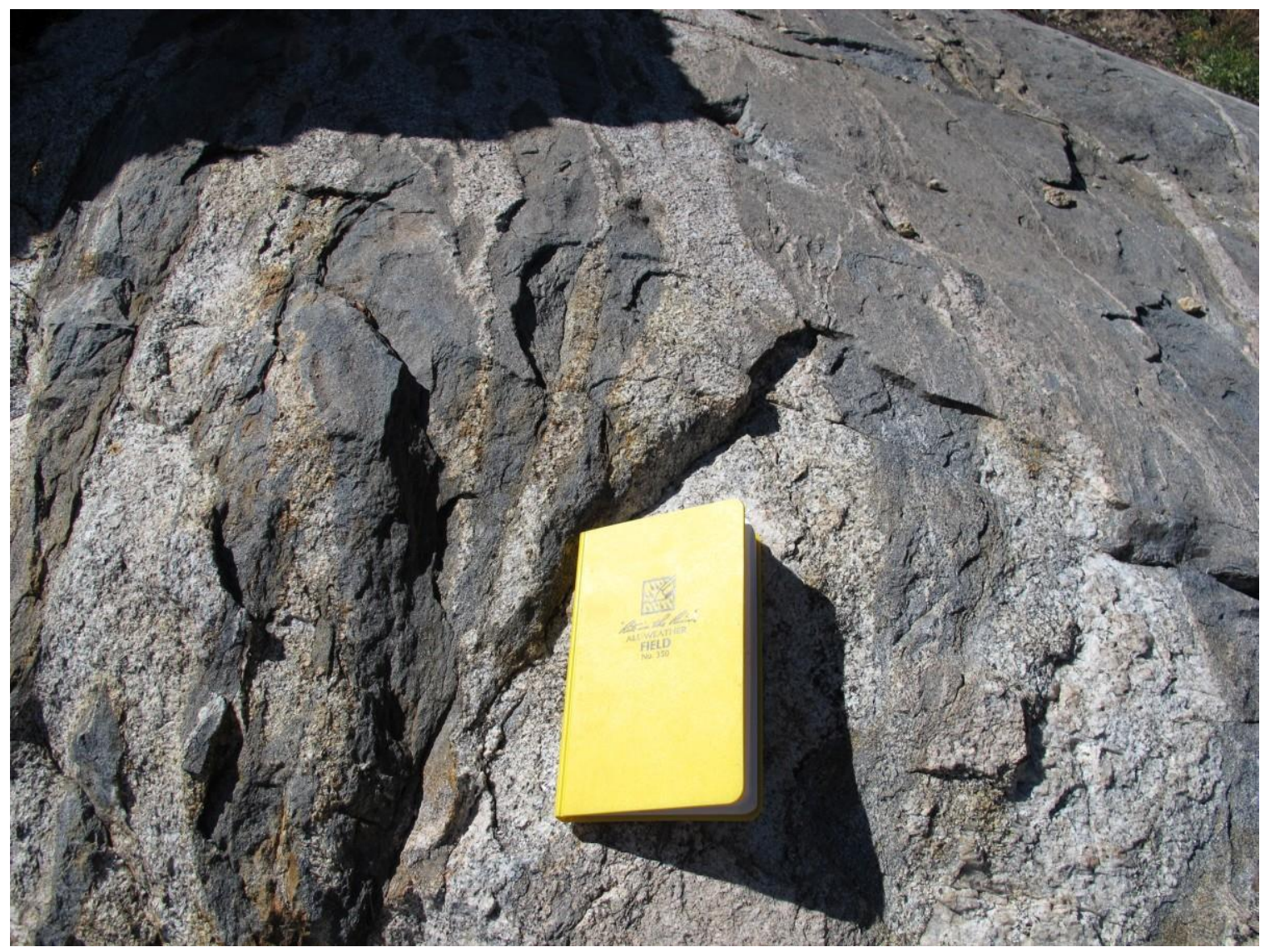

Figure 25. Lenticular xenoliths of Sailor Canyon Formation in the Pyramid Peak granite. 
lengths of up to $50 \mathrm{~cm}$. The xenoliths lack bedding and are closely associated with, and are elongate parallel to, meter-scale, irregularly shaped, unbedded blocks. The thinner xenoliths may represent pieces stripped away from the large blocks by intruding magma. Rust-colored weathering is less prevalent around these bodies.

Larger xenoliths of Sailor Canyon Formation are steeply dipping, well-bedded metaclastic rocks that are up to $1.5 \mathrm{~m}$ in thickness and up to $6 \mathrm{~m}$ in length (Fig. 26). These blocks have sharp, undulatory contacts with the Pyramid Peak granite and maintain consistent, west-dipping bedding and contacts, which roughly match the magmatic foliation of the granite. Some xenoliths are intruded along bedding by the adjacent pluton. These intrusions form sheets up to $30 \mathrm{~cm}$ thick, some of which continue through the entire xenolith. In some places, centimeter-thick felsic layers and lenses intrude between individual beds.

The 3,000 $\mathrm{m}^{2}$ quartzite block between Top Lake and Lake No. 9 (see earlier description) contains at least three gentle folds of bedding that have wavelengths of $2 \mathrm{~m}$ and amplitudes of several centimeters. Float obscures many of the contacts between this block and the host Pyramid Peak granite. An intrusion of Wrights Lake granodiorite spans the length of the block and bisects it with sharp contacts. The intrusion does not extend into the surrounding Pyramid Peak granite. 


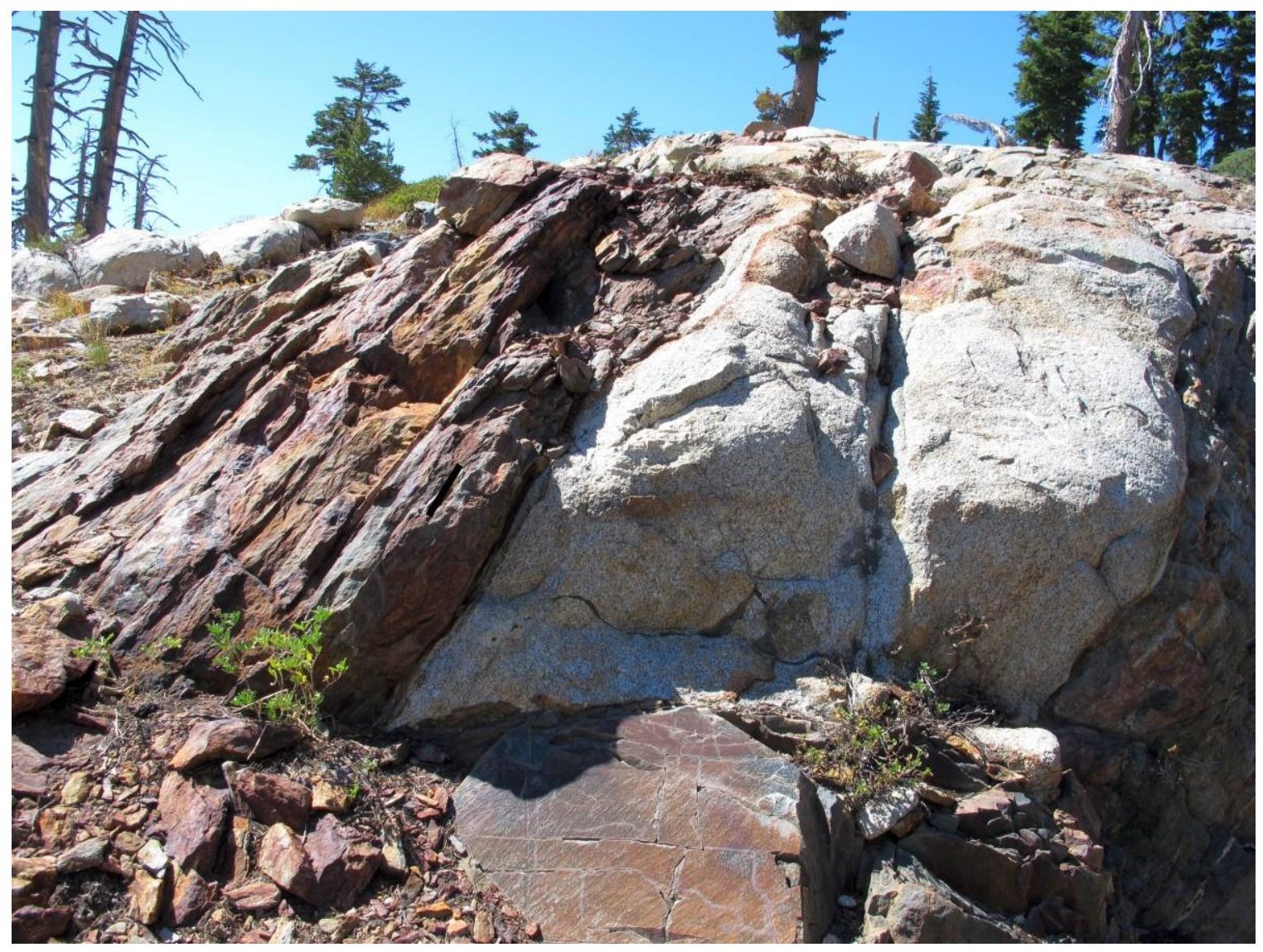

Figure 26. Pyramid Peak granite intruded concordantly between parallel rafts of bedded Sailor Canyon Formation. Black rectangle left of center traces pencil for scale $(14 \mathrm{~cm}$ long). 
Elsewhere, a $\sim 8,000 \mathrm{~m}^{2}$ block of Sailor Canyon Formation is preserved at a high elevation near the center of the pluton (Plate 1). The contacts of this block are obscured by float, and the granite infiltrates the Sailor Canyon Formation block in irregularly shaped patches and swirls. Bedding dips shallowly $\left(\sim 30^{\circ}\right)$ to the southwest. This host rock is likely a part of the pluton roof, judging by its shallow dip, isolation, and high elevation. Two other apparent roof pendants have been previously mapped at the summit of the Crystal Range near the northern border of the study area (Plate 1; Loomis, 1983; Sabine, 1992; Saucedo, 2005). These rocks are very difficult to access, but if the previous mapping is accurate, are presumed to be comparable roof pendants based on location and elevation. A single mapped bed orientation in one of these northern pendants dips $30^{\circ}$ to the southwest (Loomis, 1983), which is consistent with the dip of the beds found in the $\sim 8,000 \mathrm{~m}^{2}$ block.

To the east, the contact between the Pyramid Peak granite and the western margin of the main Mount Tallac pendant of the Sailor Canyon Formation is generally obscured by talus and Quaternary till. Discordant dikes of granite, ranging up to $1.5 \mathrm{~m}$ thick, and thinner, non-planar granite veins intrude the host rock layers with sharp contacts (Fig. 27). These granites are medium- to fine-grained, have higher color index than the Pyramid Peak granite, and lack the coarse K-feldspars of the main pluton. 


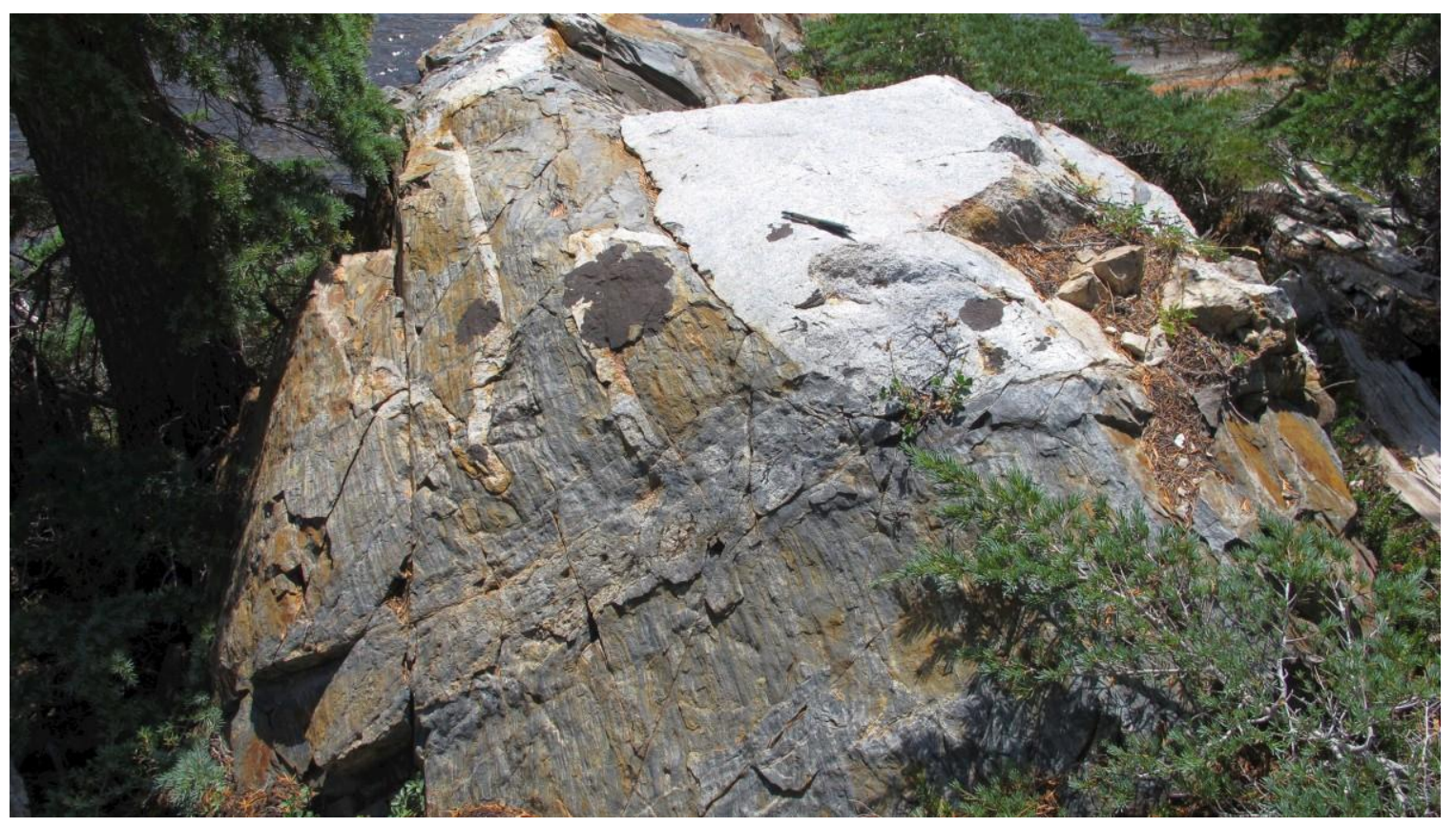

Figure 27. Non-planar bodies of Pyramid Peak granite discordantly intrude the Sailor Canyon Formation.

\section{Wrights Lake Granodiorite - Sailor Canyon Formation Contact}

The northern area is the only place in the study area where the Wrights Lake granodiorite comes in contact with pieces of the Sailor Canyon Formation (Plate 1). The granodiorite in this area incorporates xenoliths of Sailor Canyon Formation over a roughly 40,000 $\mathrm{m}^{2}$ area. The largest xenoliths reach up to $6 \mathrm{~m}$ across. Bedding within the larger blocks consistently dips $60-65^{\circ}$ to the west (Fig. 28). As with the Pyramid Peak granite, the Wrights Lake granodiorite intrudes the layers both concordantly and discordantly (Figs. 28 and 29). Thin concordant sheets of felsic minerals impart a banded appearance to some xenoliths, whereas other xenoliths are cross-cut by discordant sheets of Wrights Lake granodiorite, which range from 0.3 to $0.6 \mathrm{~m}$ in thickness. 


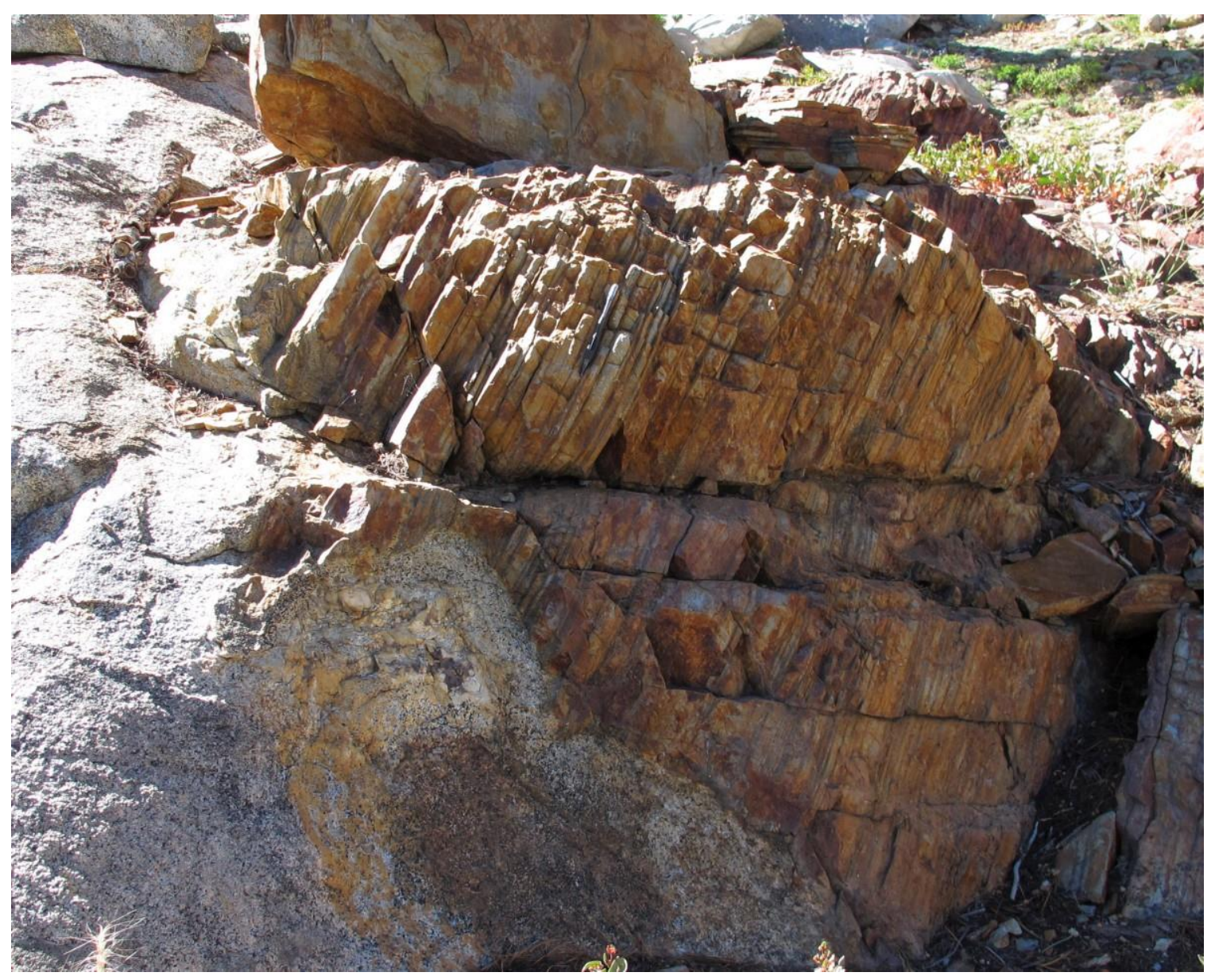

Figure 28. Wrights Lake granodiorite cuts discordantly through steep bedding of a Sailor Canyon Formation xenolith. $14 \mathrm{~cm}$ mechanical pencil for scale above photo center. 

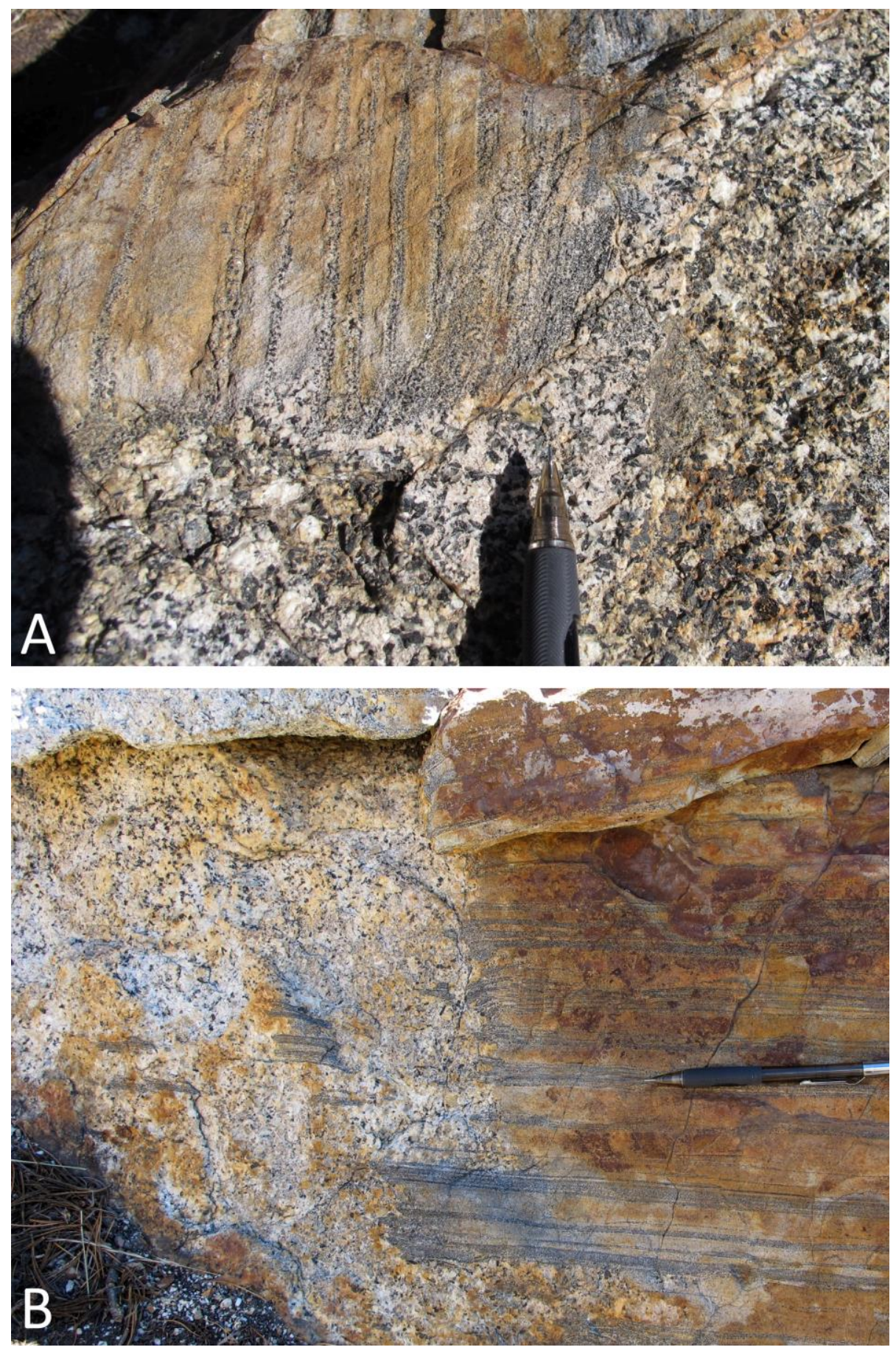

Figure 29. Wrights Lake granodiorite infiltrates Sailor Canyon Formation xenoliths. (A) Close-up of xenolith edge showing fine-grained plutonic material intruding xenolith, with possible deflection of layers near tip of pencil. (B) Layered pieces of Sailor Canyon Formation isolated by discordant intrusions of Wrights Lake granodiorite. 
The strike of the xenolith beds matches the strike of the dominant foliation in the surrounding pluton, and both are aligned parallel to the pluton margin. Unlike the consistent west dips of the beds, the magmatic foliation dips eastward. The second, nonmargin-parallel magmatic foliation typically found in the Wrights Lake granodiorite is weak or absent near these xenoliths.

\section{Wrights Lake Granodiorite - Pyramid Peak Granite Contact}

The N-NNW-trending boundary between the Wrights Lake granodiorite and Pyramid Peak granite spans the entire field area (Plate 1). Most of the contact is relatively straight in plan view on the map scale, except for an embayment and stepover in the middle of the area and for smaller bends in the south. The contact is sharp and dips moderately to steeply eastward. In a few locations, the Wrights Lake granodiorite abuts diorite host rather than the more abundant granite.

The Wrights Lake granodiorite rarely cuts into the Pyramid Peak pluton beyond its margin, but locally does so in two ways. In the northern area, where the host is diorite, a few $<1$-m-thick, angular "arms" extend into the host pluton. These intrusions contain enclaves, and grains are aligned parallel to the "arm" margin, reflecting material flow. Two isolated dike-like bodies of Wrights Lake granodiorite also intrude the Pyramid Peak granite. These bodies have sharp, stepped boundaries, are $\sim 2.5 \mathrm{~m}$ wide, and reach no more than $15 \mathrm{~m}$ in length.

The overall straight Wrights Lake granodiorite-Pyramid Peak granite contact has finer-scale irregularities. Angular protrusions of Pyramid Peak granite extend $\sim 1.2 \mathrm{~m}$ into the younger pluton. In each case, an intrusion of the younger pluton cuts back into 
the Pyramid Peak granite protrusion, as if solidified in the process of detaching the protrusion as a xenolith (Fig. 30). Fully isolated granite xenoliths are limited to within 6 $\mathrm{m}$ of the contact, and occur as: isolated feldspar xenocrysts; rounded pieces, $5-24 \mathrm{~cm}$ in diameter; wispy "tendrils" of granite reaching up to $1 \mathrm{~m}$ in length and 1-4 $\mathrm{cm}$ in width; and larger blocks of varying shapes and sizes, ranging up to $3.5 \mathrm{~m}$ in length (Figs. 31 and 32). Some of the large xenoliths have straight edges, and others have crenulated margins. One rectangular block, $\sim 2 \mathrm{~m}$ long and $\sim 6 \mathrm{~m}$ from the Wrights Lake granodiorite-Pyramid Peak granite contact, is linked to the contact by an irregular "trail" of granite (Fig. 32). Where the contact is with Pyramid Peak diorite, there are several 20-cm-thick rectangular xenoliths of diorite within $3 \mathrm{~m}$ of the Wrights Lake granodiorite. These have variable lengths of up to $1.5 \mathrm{~m}$, and are elongate parallel to the main contact.

\section{Tyler Lake Granodiorite - Pyramid Peak Granite Contact}

The Tyler Lake granodiorite is an oval-shaped pluton with a maximum diameter of $2.8 \mathrm{~km}$ and an aspect ratio of $\sim 1.5: 1$ in map view. The southern margin has a rounded 0.5 $\mathrm{km}^{2}$ embayment with an irregularly shaped, but roughly east-west oriented protrusion of the granodiorite in it (Fig. 2 and Plate 1). The pluton is surrounded on three sides by the older Pyramid Peak granite. The contact is typically obscured by Quaternary till and colluvial deposits, which hinder study. 

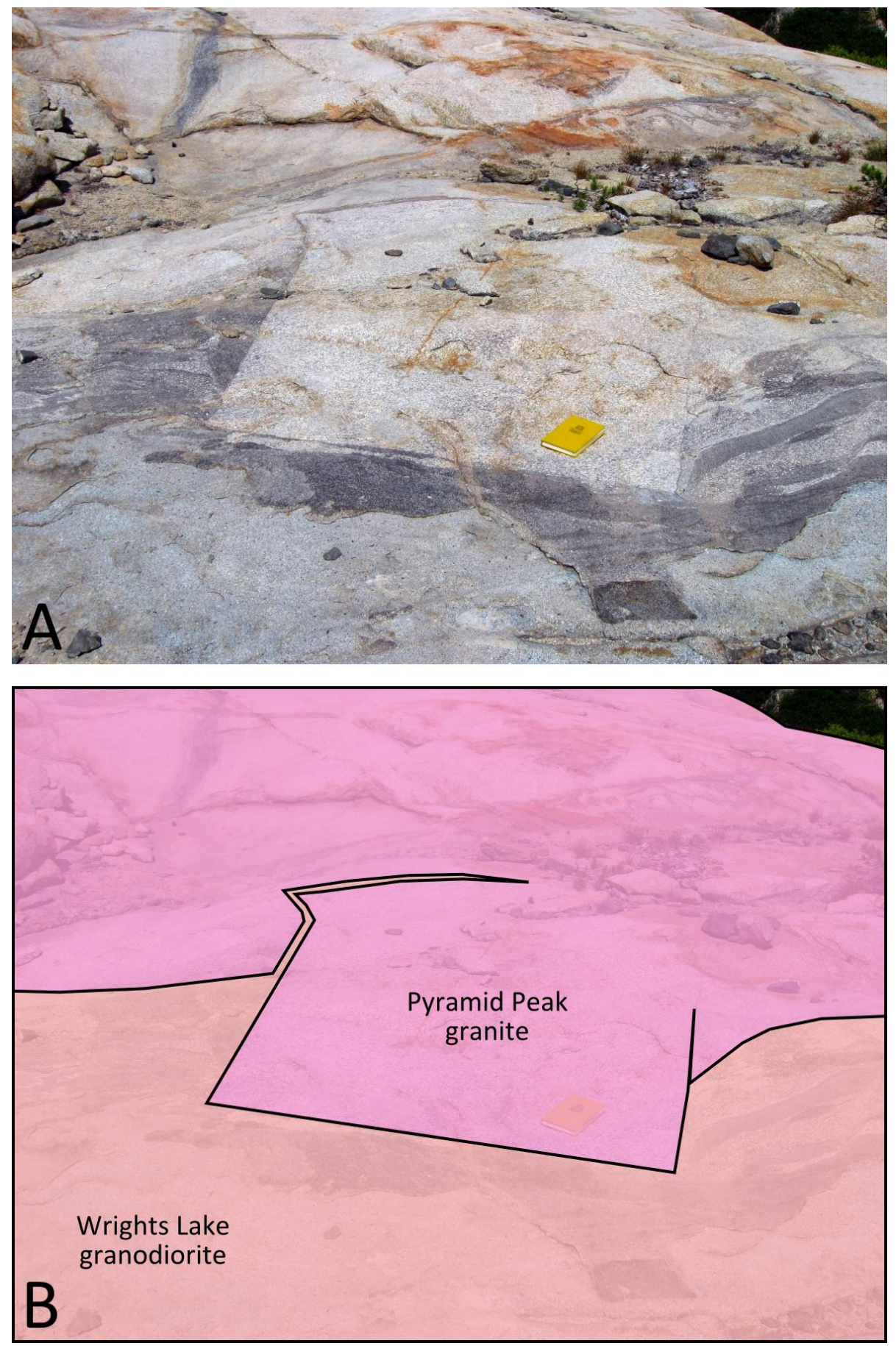

Figure 30. Angular protrusion of Pyramid Peak granite into Wrights Lake granodiorite. (A) Photo showing Wrights Lake granodiorite intruding around "block" in the early stages of xenolith formation. (B) Sketch overlay highlighting approximate pluton boundaries. 


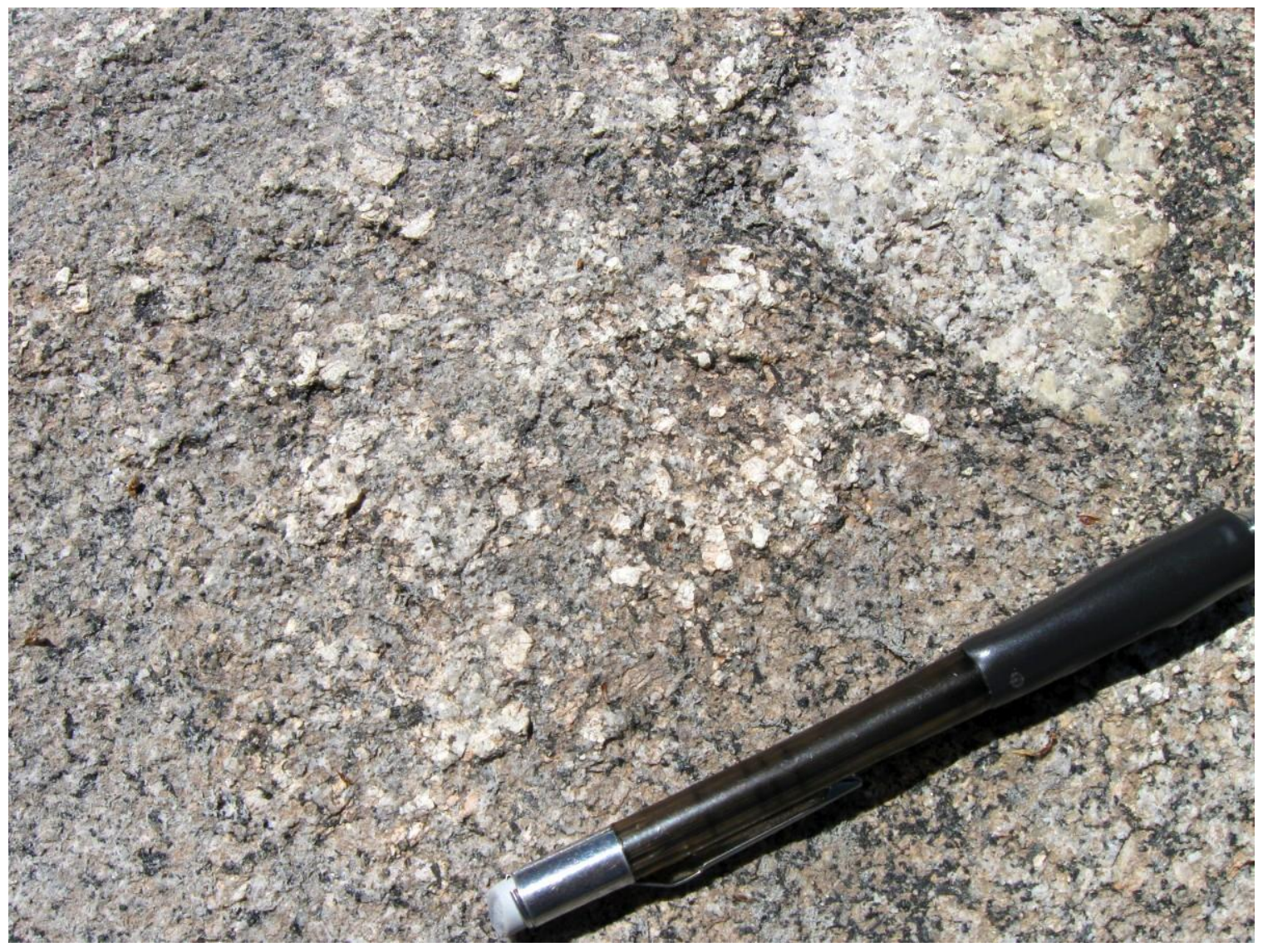

Figure 31. Xenoliths and xenocrysts of Pyramid Peak granite within the Wrights Lake granodiorite. The 6-cm-wide, diamond-shaped xenolith in the top right is bound by a cmthick rim of mafic minerals. 

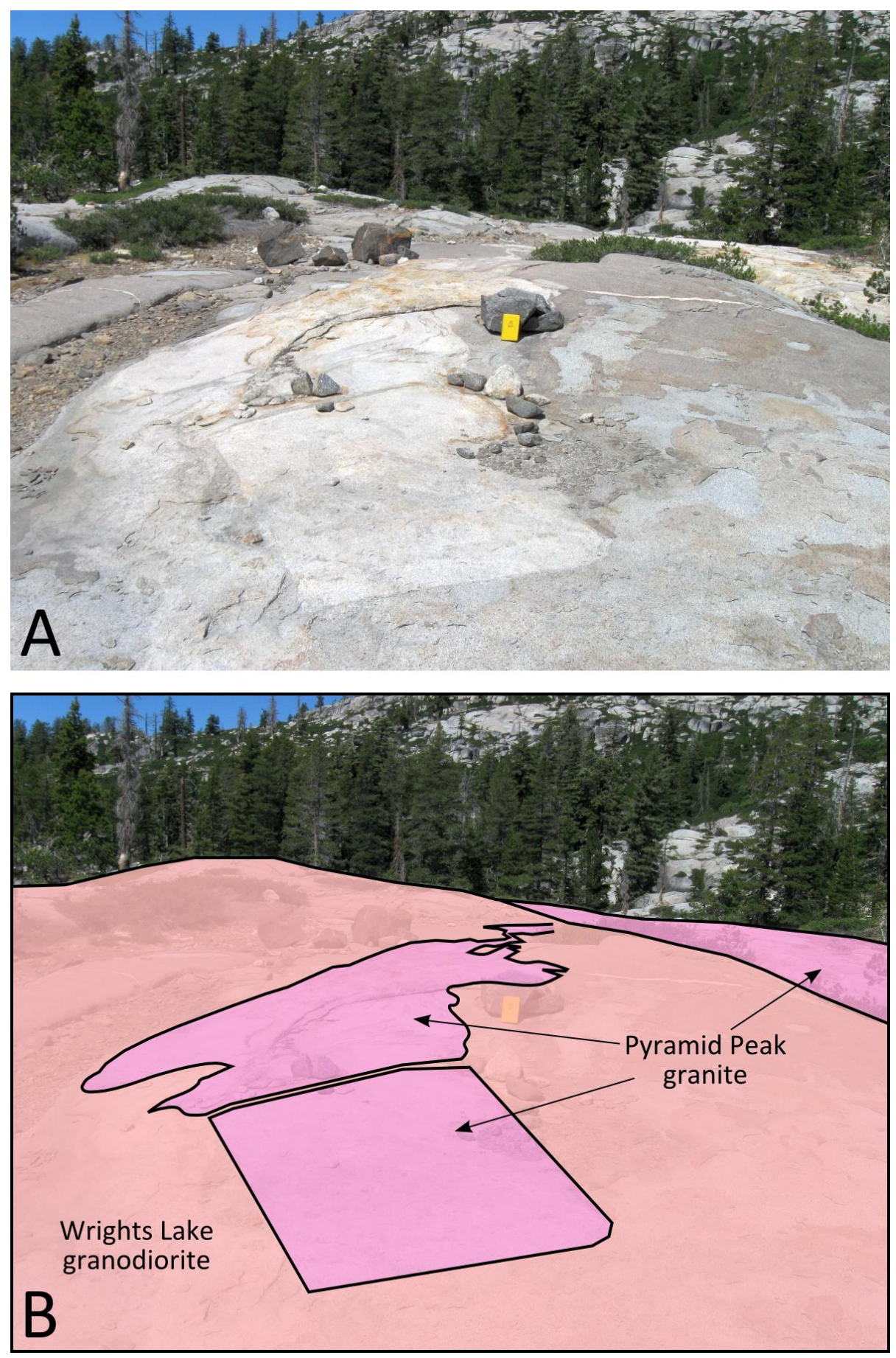

Figure 32. 2-m-long rectangular xenolith of Pyramid Peak granite in the Wrights Lake granodiorite. (A) Photo showing irregular, wavy bands of granite linking xenolith to the main Wrights Lake-Pyramid Peak contact, which is marked by the line of foliage and color contrast on the right of the photo. (B) Sketch overlay showing approximate boundaries. 
A few dikes of granodiorite intrude the diorite of the Pyramid Peak granite in areas near the unexposed contact, and generally extend $\leq 2 \mathrm{~m}$ from, and subparallel to, the inferred contact, although one is found as far as $30 \mathrm{~m}$ away. The dikes range from 3-50 $\mathrm{cm}$ in thickness, and the longest extend $5 \mathrm{~m}$ before exposure is lost. Dike contacts are sharp and vertical. Some dikes decrease in color index along their length, transitioning from the standard Tyler Lake granodioritic composition $(\mathrm{CI}=10-15)$ to almost entirely feldspar and quartz $(\mathrm{CI}<1)$.

Direct exposure of the contact is limited to short $(<10 \mathrm{~m})$ stretches where the Tyler Lake granodiorite abuts the diorite of the Pyramid Peak granite. A 1-3-cm-thick band of quartz and feldspar appears on the granodiorite side of the contact about 1-2 cm away from, and running parallel to, the contact with the diorite (Fig. 33A). The contact bends at high angles and truncates an enclave swarm (Fig. 33B).

On the protrusion on the south side of the Tyler Lake granodiorite (Plate 1 and Fig. 2), the margin of the pluton contains a zone of uncharacteristically large, 1-cm-long biotites that have no preferred orientation. This part of the contact transitions outward from typical Tyler Lake granodiorite, through the biotite-rich zone, a zone of leucocratic material, and into a zone of fine-grained mafic minerals over a $\sim 0.6 \mathrm{~m}$ transition. The fine-grained mafic zone has a diffuse boundary with the Pyramid Peak granite. 

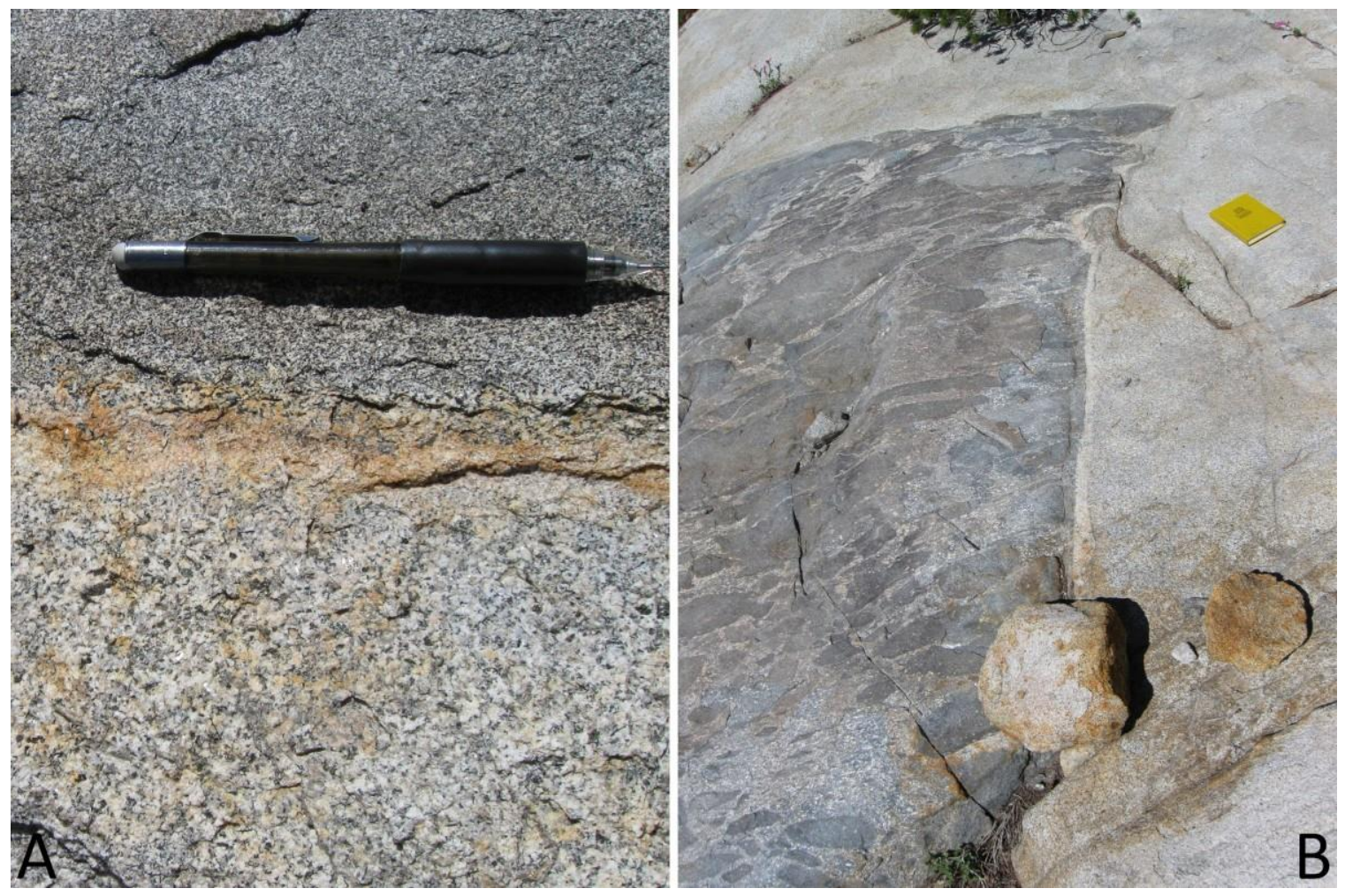

Figure 33. Intrusive contact of the Tyler Lake granodiorite with the diorite of the Pyramid Peak granite. (A) Close-up of the contact. A felsic band marks the contact. (B) A sharp bend in the contact where the Tyler Lake granodiorite truncates a zone of elongated enclaves in the Pyramid Peak pluton. Notice the felsic band along the margin, as in (A). 


\section{DISCUSSION}

\section{Pluton Construction}

It is well established that plutons are constructed from multiple influxes of magma. The size, shape, orientation, and tempo of those influxes are considerably less certain, and researchers have arrived at a range of conclusions. Workers have proposed that different plutons were constructed by intrusions in close succession (e.g., Wiebe and Collins, 1998; Miller and Paterson, 2001; Matzel et al., 2006), or by an amalgamation of discrete increments over a longer period of time (e.g., Coleman et al., 2004; Glazner et al., 2004; Michel et al., 2008), and both models have been considered for plutons of the Sierra Nevada batholith, like the Tuolumne Intrusive Suite. It is thus useful to analyze additional plutons to determine which of the two end member models (if either) are applicable. The construction of the Pyramid Peak granite, Wrights Lake granodiorite, and Tyler Lake granodiorite are considered below.

\section{Construction of the Pyramid Peak Granite}

The Pyramid Peak granite is a clear example of a pluton constructed from more than one type of magma. Less than one half of the areal extent of the pluton contains diorite and/or diorite-granite hybrid rock, in varying proportions (Plate 1). The largest coherent body of homogenous diorite exceeds $0.5 \mathrm{~km}^{2}$. The rest of the pluton is solely granitic. Additional diorites interpreted by Loomis (1993) to predate the Pyramid Peak granite intrude the Sailor Canyon Formation to the east, but their relationship to the diorite within the Pyramid Peak granite is uncertain. If related, they are near the stratigraphic bottom of the original magma chamber, based on the west-dipping orientation of bedding 
in the Sailor Canyon Formation and on the synformal nature of the pluton identified by Wiebe et al. (2002) and discussed below.

Wiebe et al. (2002) presented a model for pluton construction based on the relationship between the granites and diorites within the Pyramid Peak pluton. According to Wiebe et al. (2002), a tilted series of mafic-silicic layered intrusions (MASLI) formed this pluton, seen just south of the study area at Island Lake. In the Island Lake area, five northwest-striking diorite layers, tens of meters thick, have chilled bases and grade upward (southwestward) into leucocratic granite. The layers are inferred to represent periodic intrusions of mafic magma, which ponded on the aggrading floor of a silicic magma body. The upper portion of each mafic layer then mixed with its host via convection, producing the gradational hybrid rock. The original dip of these layers, recorded by the orientations of granitic pipes and the asymmetry of load casts, was 10 to $20^{\circ}$ to the west, according to Wiebe et al. (2002). The contacts now dip up to $60^{\circ}$ southwest and are mapped as part of a synform, which would suggest floor subsidence below the building pluton (Wiebe et al., 2002).

The MASLI layers of Island Lake cannot be traced to the north due to the later intrusion of the Tyler Lake granodiorite. North of the Tyler Lake granodiorite, diorites are more chaotic and do not form distinct layers, making it difficult to test the MASLI model. The rocks on the northern and western side of the Tyler Lake granodiorite are granite, diorite, and hybrid rocks interspersed in no overarching pattern. Diorites range from rounded or angular, isolated, sub-meter enclaves, to meter-scale bodies cross-cut by granite veins and dikes. Some outcrops have more fluid-like relationships between the 
magma types, with granite veins appearing to intrude diorite with a high melt fraction. Heterogeneous textures and mineral modes imply that hybridization is common. Other outcrops display greater rheological contrast and diorite bodies have sharp, angular edges. These diorites show local centimeter-scale flame structures of granite into the diorite. The lack of distinct diorite layers makes these structures difficult to correlate to the orientations of the MASLI flame structures identified by Wiebe et al. (2002). If the compositional heterogeneities in the Pyramid Peak pluton were originally distributed in MASLI-style layers, there must have been much mobilization of magma in the late stages of crystallization to disrupt these layers.

Within the exclusively granitic parts of the pluton, it is difficult to recognize distinct individual bodies. Truncations of enclave swarms suggest internal contacts between different pulses of magma, but such features are sparse (Fig. 5B). Portions of the pluton grade into zones with a smaller maximum size of K-feldspar phenocrysts, which may indicate separate increments of magma.

The most noteworthy exception to the lack of obvious granite-granite internal contacts relates to a domain of strong solid-state deformation in the granites and diorites near Maude Lake (Plate 1). There, the domain of solid-state foliation, which measures at least $150 \mathrm{~m}$ by $150 \mathrm{~m}$, is abruptly truncated at a high angle by granite only possessing a magmatic foliation. This relationship indicates a period of deformation of sub-solidus rock followed by the influx of a subsequent increment of magma. Fabrics are consistently oriented across the contact, striking roughly north-south and dipping moderately steeply to the west. This consistency between solid-state and magmatic 
foliations may indicate that both fabrics reflect the regional strain field, and have no relation to pluton construction processes.

The other solid-state shear zones in the Pyramid Peak granite suggest separate increments of magma, particularly the 50-cm-thick mylonite zone. This shear zone is strongly deformed with sigma and delta K-feldspar porphyroclasts, yet the adjacent diorite has no apparent solid state shear. This relation suggests shear on a sub-solidus granite, cross-cut by a later influx of diorite.

The consistent $\sim 162^{\circ}$ strike throughout the Pyramid Peak pluton may record regional WSW-ENE shortening at the Jurassic/Cretaceous boundary. This is consistent with the regional strain recorded by the nearby Jurassic Keiths Dome pluton (Clay and Miller, 2010; Clay 2014). However, this foliation is also concordant to the overall tabular, NNW-trend of the pluton, so the possibility that this is a margin-parallel fabric established by internal processes cannot be entirely ruled out.

\section{Construction of the Wrights Lake Granodiorite}

In most cases, it is difficult to determine the shape and size of an increment of magma unless there are noticeable compositional or textural heterogeneities or truncations of magmatic features. With few exceptions, the Wrights Lake granodiorite is homogeneous throughout the field area. Minor zones of increased or decreased color index appear near parts of the contact with the Pyramid Peak granite. High-color-index areas are typically gradational with the surrounding granodiorite, but leucocratic rocks tend to have sharp contacts, and mingle with the typical granodiorite with intricate lenses (Fig. 6); some incorporate granodiorite enclaves. The leucocratic rocks could represent distinct magmas 
that solidified before they could homogenize with the granodiorite, or they may be the result of fractionation.

Homogeneity in a pluton can be evidence of the thorough mixing of magmas in a single magma chamber, or in smaller contemporaneous increments. Due to the large size $\left(>775 \mathrm{~km}^{2}\right)$ of the pluton, it is very unlikely that this pluton was ever a single, active magma chamber. Despite this, there is very little compelling evidence of incremental emplacement of this pluton (e.g., internal contacts, compositional and textural heterogeneities).

Microgranitoid enclaves are ubiquitous throughout the pluton, demonstrating that the intrusion of a more mafic melt contributed to the construction of the pluton. These enclaves generally lack a preferred orientation, giving no indication of flow directions. The two short (15 $\mathrm{m}$ and $3 \mathrm{~m}$ ) syn-plutonic dikes recognized in this study (Fig. 11) may represent small feeder channels inputting mafic magma into a granodiorite magma.

The magmatic fabric patterns of the Wrights Lake granodiorite bear on the construction of the pluton. In the earliest maps of the Wrights Lake granodiorite, magmatic foliations were depicted and described as forming elliptical patterns roughly 1 $\mathrm{km}$ in diameter (Loomis, 1983). These types of patterns in a pluton were interpreted to reflect a chamber comprised of large, contemporaneous, convective cells. Convective mixing and cell migration were cited to explain the homogeneity of the pluton (Loomis, 1983).

During this study, the elliptical foliation patterns could not be identified. Instead, measurements revealed that the pluton has two overprinting, steep magmatic foliations. 
One is oriented approximately east-west, and the other is roughly north-south and subparallel to the pluton margin. Plutons containing multiple overprinting foliation patterns have been recognized in recent years. Examples include the Tuolumne Intrusive Suite $\sim 130 \mathrm{~km}$ southeast of this study area (Žák et al., 2007), the Main Donegal pluton in Ireland, and the Entiat and Mount Stuart plutons in Washington (Paterson et al., 1998). These multiple-fabric plutons are interpreted to record both regional strain and internal magmatic processes near the time of final crystallization (Žák et al., 2008).

In the Wrights Lake granodiorite, the east-west foliation is orthogonal to the margin of the pluton and unmistakably discordant, which implies that it is unrelated to internal processes and instead records mid-Cretaceous regional north-south shortening (cf. Paterson et al., 1998). The north-south fabric is parallel to the eastern margin of the pluton, bending into parallelism with a large embayment in the contact near the center of the field area. A margin-parallel foliation is typically interpreted to be evidence of internal magmatic processes, such as convection, filter pressing, flow of magma along the walls of a chamber, or a concentric magma-chamber expansion (Paterson et al., 1998).

\section{Construction of the Tyler Lake Granodiorite}

The Tyler Lake granodiorite is a homogeneous pluton, and has no significant accumulations of schlieren, enclaves, or other internal structural features. There are no major compositional variations or obvious internal contacts, making it difficult to draw conclusions about the construction of the pluton.

The Tyler Lake granodiorite was originally mapped as a $2.3 \mathrm{~km}^{2}$ oval-shaped pluton with a simple, margin-parallel, "onion-skin" foliation (Loomis, 1983). The size and 
shape of the Tyler Lake granodiorite has since been considerably refined from its original mapped form into a larger $\left(4 \mathrm{~km}^{2}\right)$, more irregular shape (Sabine, 1992), so it remained to be determined whether the margin-parallel foliation pattern was still applicable.

Due to the fine grain size and low color index of this granodiorite, magmatic fabrics are difficult to identify. The measurements collected on the western and southern sides of the pluton do not define a preferred orientation (Figs. 2 and 19), even in the biotite-rich domain on the southern margin where a fabric would most likely be conspicuous. The margin-parallel, "onion skin" foliation is not found, and is not expected to be found on the unstudied northern and eastern margins, due to the homogeneity of the pluton. Therefore, there is no evidence of filter pressing or magma flow against the pluton walls during the construction of this pluton. There is also no record of regional tectonic strain imprinted upon this pluton.

The homogeneity of the pluton and lack of internal magmatic features are compatible with the construction of the Tyler Lake granodiorite by a single pulse or by multiple batches of magma intruded over a short enough period to allow for a thorough mixing of the magmas. In this scenario, the magmas form a single chamber.

\section{Pluton Emplacement}

When a pluton intrudes the crust, an equivalent volume of host material must be displaced to accommodate the new rock. A number of mechanisms have been proposed to displace host material, including the stoping of host rock, uplift of the pluton roof, sinking of the floor, ductile straining of the surrounding rock, dilation by extension, and wedging apart of host rock by sheets (e.g., Buddington, 1959; Pitcher and Berger, 1972; 
Corry, 1988; Hutton, 1996; Paterson et al., 1996; Wiebe and Collins, 1998; Cruden and McCaffrey, 2001; Miller and Paterson, 2001; Glazner and Bartley, 2006). It is likely that multiple processes aid the emplacement of any given pluton, and those processes may vary based on composition, rheology, crustal depth, pressure/temperature conditions, and tectonic setting.

\section{Emplacement of the Pyramid Peak Granite}

The emplacement of the Pyramid Peak granite is difficult to evaluate due to the scarcity of remaining host rock contacts, most of which have been eliminated by the intrusion of younger plutons. There are two main areas that provide insight into the emplacement history of this pluton: the xenoliths in the northern area near the western contact and the eastern contact with the main host pendant.

The northern area contains a number of xenoliths of the Sailor Canyon Formation (Plate 1). Steep contacts and beds are parallel and consistent between multiple isolated xenoliths (Fig. 26). The parallel orientations of the xenoliths suggest that these are rafts that were isolated by injections of subvertical, concordant sheets. Alternatively, the xenoliths could have rotated independently in a magma body, but their consistency makes this less likely. The steepness of the rafts suggests that an adjacent host remnant (subsequently removed by the intrusion of the Wrights Lake granodiorite) was either steep before emplacement, or more likely, rotated due to emplacement. It is probable that these host rafts are remnants of the sidewall of the pluton, although it is difficult to evaluate this possibility without adjacent undisturbed host for comparison. The beds of the roof pendants (described in Intrusive Relationships) dip $\sim 30^{\circ}$ to the west and may 
provide a proxy for the orientation of host bedding prior to pluton emplacement. The steep bedding of the sidewall would reflect the rigid rotation of the host, which was then dissected by magma wedging of granite sheets, demonstrating that the entire pluton was not intruded in MASLI-style sheets. Rafts of similar orientation appear in the Wrights Lake granodiorite in this same area, and are discussed in the next section.

Numerous amorphous, unbedded xenoliths also found throughout the northern area are likely rotated xenoliths and represent pieces of the host in various stages of digestion. It is difficult to draw many inferences about these xenoliths, other than that they demonstrate the stoping of host material into the pluton. The limited distribution of the xenoliths suggests that stoping contributed to emplacement but was not a major factor. Plutons typically do not retain large quantities of stoped blocks and their absence is a point of contention amongst researchers (cf. Glazer and Bartley, 2006; Paterson et al., 2008; Yoshinobu and Barnes, 2008). The viability of dissolution and partial melting of xenoliths has been debated (Clarke et al., 1998; Glazner, 2007; Glazner and Bartley, 2008; Yoshinobu and Barnes, 2008, and references therein). The amorphous shapes of many of these xenoliths support dissolution of the block edges, but the geochemical analysis needed to test this interpretation is beyond the scope of this study.

The other major host locality is the eastern contact of the pluton with the Sailor Canyon Formation. The Pyramid Peak-Sailor Canyon contact is obscured by Quaternary cover, but the contact is likely sharp (Plate 1). Bedding dips moderately westward adjacent to (and toward) the contact. If the contact is discordant to bedding, the Sailor Canyon Formation here would represent the sidewall of the pluton. If the contact is 
concordant to bedding, however, as it is for the western rafts, then the Sailor Canyon Formation is the floor of the pluton. Wiebe et al. (2002) used the steep, southwestward dips of the mafic and silicic layers and other way-up indicators to infer that this host rock is the floor of the intrusion and that the pluton is synformal. The east-plunging granitic pipes near Maude Lake (described above) support a $10-20^{\circ}$ rotation of the pluton toward the west following construction, which is consistent with the $10-20^{\circ}$ rotation identified by Wiebe et al. (2002). In this case, the dip of bedding could be partially attributed to floor sinking below the growing pluton, as also inferred by Wiebe et al. (2002).

Some plutons have an increase in ductile strain of the host near the margin, indicating ductile flow of material to accommodate emplacement (e.g., Hutton, 1982; Paterson and Vernon, 1995; Clay, 2014). No obvious structural aureole was identified in the Sailor Canyon Formation that would point to ductile flow as a mechanism.

Other models predict that emplacement could be facilitated by a pre-existing or active fault or shear zone along which magma could easily intrude (e.g., Hutton and Reavy, 1992; Tikoff and Teyssier, 1992). The overall lack of available host material makes it difficult to evaluate this mechanism for the Pyramid Peak granite. The Sailor Canyon Formation is faulted to the east (Fisher 1989), but there are no known faults that bound the pluton or extend along strike to the north-northwest or south-southeast.

One possible interpretation of the emplacement of this pluton, based on the steeply west-dipping rafts on the west side of the pluton and the modestly west dipping bedding in the pendant on the east side, is that the pluton is a laccolithic intrusion (Plate 1). The formation of a laccolith involves concordant intrusions of magma into a bedded host, 
forcing the uplift of the pluton roof, resulting in a convex-upward, lens-shaped pluton with host bedding draped over the top (Corry, 1988). In the case of the Pyramid Peak granite, the steeply dipping rafts to the west could potentially be the result of the upward deflection of bedding around the edges of the pluton due to non-piston-like uplift of the roof. The shallow-dipping pendant to the east, assuming intrusive concordance, would be the floor of the laccolith. The dip of the pendant bedding can be attributed to a modest amount of floor sinking beneath the growing pluton, and the $10-20^{\circ}$ westward rotation of the entire laccolith, recognized in this study and in that of Wiebe et al. (2002).

In summary, the emplacement of the Pyramid Peak granite was accommodated in part by rigid block rotation of the sidewall or non-piston-like uplift of the roof, and by floor sinking below the pluton. There is no available evidence for brittle, piston-like uplift of the roof. Brittle material transfer of the host by stoping contributed to pluton emplacement, but was probably not a major factor.

\section{Emplacement of the Wrights Lake Granodiorite}

The Wrights Lake granodiorite may exceed $775 \mathrm{~km}^{2}$ (Loomis, 1983), so much host material must have been displaced to accommodate the intrusion of the pluton. Within the study area, the only host rock is the Pyramid Peak granite and xenoliths of Sailor Canyon Formation.

The xenoliths of Sailor Canyon Formation are exposed near those in the northern part of the Pyramid Peak granite (Plate 1). These steeply west-dipping, bedded xenoliths are nearly identical in orientation to each other and to the rafts within the Pyramid Peak granite (Fig. 28). Their proximity across the contact suggests that these rafts are part of 
the host that remained adjacent to the Pyramid Peak granite after emplacement. Discordant and concordant sheets of the Wrights Lake granodiorite later intruded these host rocks to the Pyramid Peak margin, which acted as a rheological boundary. The rafts show fine-scale infiltration along bedding (Fig. 29A) and pieces of these beds can be traced into the granodiorite, separated by granodiorite (Fig. 29B). In addition to these rafts, other local bedded and unbedded, irregularly shaped xenoliths of Sailor Canyon Formation are found in the granodiorite and probably represent stoped material. In some cases, these xenoliths are cut discordantly by thin (tens of $\mathrm{cm}$ ) granodiorite dikes with minimal offset of bedding, so some of these could potentially be in-place rafts as well.

Xenoliths of Pyramid Peak granite can only be found within $6 \mathrm{~m}$ of the contact, and are mostly confined to the southern half of the study area. None of these xenoliths occur amongst the Sailor Canyon Formation rafts and xenoliths of the northern area. Granite xenoliths appear in a variety of forms, including as rectangular blocks, rounded pieces, disaggregating "chunks," and isolated xenocrysts of K-feldspar (Figs. 31 and 32). These features demonstrate the transfer of host into magma by stoping, and that some xenoliths later broke apart, which may help explain the lack of xenoliths farther from the contact.

One $\sim 2$-m-long rectangular granite xenolith is $\sim 6 \mathrm{~m}$ from the contact. This xenolith is noteworthy in that it is an angular xenolith linked to the contact by a narrow, irregular "trail" of Pyramid Peak granite (Fig. 32). This "trail" ranges in thickness from $20 \mathrm{~cm}$ to $1.5 \mathrm{~m}$ and contains centimeter-scale wisps of Wrights Lake granodiorite that run parallel to the long axis of the "trail." In places, the granite mingles with the granodiorite, suggesting remobilization of the granite host. This xenolith is difficult to interpret as a 
raft offset by diking, and instead demonstrates that stoping was a factor in accommodating emplacement of the Wrights Lake granodiorite.

In addition to xenoliths, there are angular, sharp-edged protrusions of Pyramid Peak granite that show partial detachment into the granodiorite (Fig. 30). Wrights Lake granodiorite has intruded into the host and partially excavated xenoliths, but solidified prior to completion. These features further demonstrate the process of stoping.

Aside from xenoliths and evidence of stoping, there is little other evidence to resolve the emplacement mechanisms for this pluton. There is no observable deflection in the fabric of the host pluton. The consistency of the orientations of the Sailor Canyon Formation rafts in both Wrights Lake and Pyramid Peak plutons also suggests a lack of host rotation resulting from the emplacement of the younger granodiorite. There is no increase in ductile strain of the Pyramid Peak pluton at the margin and no solid-state foliation or lineation in either host rock that would indicate ductile flow. The overall lack of country rock prevents evaluation of fault dilation as an emplacement method.

Regionally, the age relationships between the Wrights Lake granodiorite and its surrounding Cretaceous plutons (Fig. 1) are unclear, and the western margin of the granodiorite is unknown (Saucedo, 2005). If future studies determine that these adjacent plutons predate the Wrights Lake granodiorite, a more complete story of the emplacement of the pluton could be developed by studying these contacts. The early KAr work of previous authors suggests that the southern plutons are younger (Evernden and Kistler, 1970), but higher precision U-Pb dating of zircon is needed to provide a definitive timeline. 


\section{Emplacement of the Tyler Lake Granodiorite}

Of the three plutons, the Tyler Lake granodiorite has the least direct evidence of material transfer processes during its emplacement. There are no xenoliths of the host rock that would indicate stoping. The Tyler Lake granodiorite primarily intrudes the Pyramid Peak granite, which shows no sign of rotation of foliation, although it would be difficult to recognize due to the weak fabric (Fig. 19). There is no structural aureole in the host that would imply ductile flow, and no major faults extend from the pluton that would point toward fault dilation accommodating emplacement.

The rare glimpses of the poorly exposed pluton margin indicate that there are at least some small-scale angular boundaries and the truncation of an enclave swarm (Fig. 33B), which may indicate brittle material transfer by stoping, despite the lack of xenoliths. The pluton boundary is sharply discordant to map-scale host units and features, including the MASLI-style layers at Island Lake, which also supports a brittle emplacement (Plate 1). The composition of the granodiorite differs over a several-cm to tens-of-cm margin against the Pyramid Peak granite, which is compatible with filter pressing of a magma against its host during emplacement. The short dikes extending from the pluton indicate that some amount of wedging into the Pyramid Peak pluton may have occurred.

\section{Regional Strain}

The probable regional foliation in the Pyramid Peak granite suggests a period of WSW-ENE regional shortening around $144 \mathrm{Ma}$, which is consistent with evidence from

the Jurassic Keiths Dome pluton, 10 km to the east (Clay and Miller, 2010; Clay 2014). The Wrights Lake granodiorite records N-S shortening at around $106 \mathrm{Ma}$. This younger 
strain field is consistent with regional strain recorded by the Half Dome granodiorite ( 92-91 Ma) and Cathedral Peak granodiorite (88-86 Ma) of the Tuolumne Intrusive Suite, $\sim 130 \mathrm{~km}$ to the southeast (Teruya, 2005; Žák et al., 2007). The origin of this fabric remains enigmatic, however, and does not reflect the typical middle Cretaceous strain field for the Sierra Nevada region (e.g., Tobish et al., 1995). Data from this study suggest that the regional strain field affecting the Sierra Nevada batholith transitioned from WSW-ENE shortening to N-S shortening between $144 \mathrm{Ma}$ and $106 \mathrm{Ma}$. 


\section{CONCLUSIONS}

1) The Pyramid Peak granite is a heterogeneous pluton with abundant granite, mafic and hybrid rocks. Within the study area, the pluton is not recognizable as a MASLI except at the very southern boundary, suggesting disruption by complex magmatic activity at the late stages of crystallization in an incrementally built chamber. Magmatic fabric is likely the result of regional WSW-ENE shortening during emplacement in the Early Cretaceous, but the influence of magmatic processes cannot be ruled out.

2) Sheets of the Pyramid Peak granite intruded into the Sailor Canyon Formation and rotated the sidewall, possibly through non-piston-like roof uplift over a lensshaped pluton. Depression of the pluton floor may have helped accommodate emplacement. Xenoliths provide evidence for brittle material transfer of host (i.e., stoping), but not in significant volumes.

3) The Wrights Lake granodiorite is a mostly homogeneous pluton containing abundant microgranitoid enclaves and schlieren. Although it is unlikely to have formed as a single, large magma chamber, there is very little compelling evidence for incremental construction. The pluton records two overprinting foliation patterns, reflecting both magmatic processes (margin-parallel foliation) and regional strain. The east-west regional foliation demonstrates regional northsouth shortening in the mid-Cretaceous, which has been reported for the younger Tuolumne Intrusive Suite to the south, but has not been recognized elsewhere in the Sierra Nevada range. There are no map-scale elliptical foliation patterns. 
4) The Wrights Lake granodiorite intruded the Pyramid Peak granite and dissected a pendant of the Sailor Canyon Formation. Brittle material transfer of these hosts into the magma was a contributing factor in accommodating emplacement. There is no evidence of a ductile strain aureole in the host rocks.

5) Based on the differences in regional foliation patterns, the regional strain field in the northeast Sierra Nevada Mountains changed from ENE-WSW to N-S shortening over a $\sim 38$ myr period between $\sim 144$ and $\sim 106$ Ma.

6) The Tyler Lake granodiorite is a homogeneous pluton with only a weak magmatic fabric and no significant internal magmatic features. There is no margin-parallel "onion skin" foliation. The incompletely exposed contact bends and truncates local features in the host, which may indicate stoping. On the map scale, host units are cut discordantly, with no apparent deflection. The construction and emplacement of this pluton remain enigmatic. 


\section{REFERENCES CITED}

Allmendinger, R.W., Cardozo, N.C., and Fisher, D., 2012, Structural geology algorithms: vectors \& tensors: Cambridge, England, Cambridge University Press, 289 p.

Atwater, T., 1970, Implications of plate tectonics for the Cenozoic tectonic evolution of western North America: Geological Society of America Bulletin, v. 81, p. 35133535 .

Atwater, T., 1989, Plate tectonic history of the northeast Pacific and western North America, in Winterer, E.L., Hussong, D.M., and Decker, R.W., eds., The Eastern Pacific Ocean and Hawaii: Boulder, Colorado, Geological Society of America, Geology of North America, v. N, p. 21-72.

Barbey, P., Gasquet, D., Pin, C., and Bourgeix, A.L., 2008, Igneous banding, schlieren and mafic enclaves in calc-alkaline granites: The Budduso pluton (Sardinia): Lithos, v. 104, p. 147-163.

Bateman, P.C., and Chappell, B.W., 1979, Crystallization, fractionation, and solidification of the Tuolumne Intrusive Series, Yosemite National Park, California: Geological Society of America Bulletin, v. 90, p. 465-482.

Brown, M., 2013, Granite: From genesis to emplacement: Geological Society of America Bulletin, v. 125, p. 1079-1113.

Buddington, A.F., 1959, Granite emplacement with special reference to North America: Geological Society of America Bulletin, v. 70, p. 671-748.

Cardozo, N., and Allmendinger, R.W., 2013, Spherical projections with OSXStereonet: Computers \& Geosciences, v. 51, no. 0, p. 193-205.

Chapman, M., and Rhodes, J.M., 1992, Composite layering in the Isle au Haut Igneous Complex, Maine: Evidence for periodic invasion of a mafic magma into an evolving magma reservoir: Journal of Volcanology and Geothermal Research, v. 51, p. 41-60.

Clarke, D.B., Henry, A.S., and White, M.A., 1998, Exploding xenoliths and the absence of 'elephants' graveyards' in granite batholiths: Journal of Structural Geology, v. 20, p. 1325-1343.

Clay, P.J., 2014, Structure, construction, and emplacement of Jurassic and Cretaceous plutons in the Keiths Dome-Echo Lake area, southwest of Lake Tahoe, California [M.S. Thesis]: San Jose, California, San José State University, 94 p. 
Clay, P.J., and Miller, R.B., 2010, Tectonic implications of ductile shear zones in the Jurassic Keith's Dome pluton, northern Sierra Nevada batholith, California: Geological Society of America Abstracts with Programs, v. 42, no. 4, p. 99.

Coleman, D.S., Gray, W., and Glazner, A.F., 2004, Rethinking the emplacement and evolution of zoned plutons: Geochronologic evidence for incremental assembly of the Tuolumne Intrusive Suite, California: Geology, v. 32, p. 433-436.

Corry, C. E., 1988, Laccoliths; mechanics of emplacement and growth: Geological Society of America Special Paper 220, 110 p.

Cruden, A.R., and McCaffrey, K.J.W., 2001, Growth of plutons by floor subsidence: Implications for rates of emplacement, intrusion spacing and melt-extension mechanisms: Physics and Chemistry of the Earth, Part A: Solid Earth and Geodesy, v. 26, p. 303-315.

Eddy, M.P., Bowring, S.A., Miller, R.B., and Tepper, J.H., 2016, Rapid assembly and crystallization of a fossil large-volume silicic magma chamber: Geology, v. 44, p. 331-334.

Evernden, J.F., and Kistler, R.W., 1970, Chronology of emplacement of Mesozoic batholithic complexes in California and western Nevada: U.S. Geological Survey Professional Paper 623, 42 p.

Fisher, G.R., 1989, Geologic map of the Mount Tallac roof pendant, El Dorado County, California: U.S. Geological Survey Miscellaneous Field Studies Map MF-1943, scale 1:24,000.

Fisher, G.R., 1990, Middle Jurassic syntectonic conglomerate in the Mount Tallac roof pendant, northern Sierra Nevada, California, in Harwood, D.S., and Miller, M.M., eds., Paleozoic and early Mesozoic paleogeographic relations; Sierra Nevada, Klamath Mountains, and related terranes: Geological Society of America Special Paper 255, p. 339-350.

Glazner, A.F., 2007, Thermal limitations on incorporation of wall rock into magma: Geology, v. 35, p. 319-322.

Glazner, A.F., Bartley, J.M., Coleman, D.S., Gray, W., and Taylor, R.Z., 2004, Are plutons assembled over millions of years by amalgamation from small magma chambers?: GSA Today, v. 14, p. 4-11.

Glazner, A.F., and Bartley, J.M., 2006, Is stoping a volumetrically significant pluton emplacement process?: Geological Society of America Bulletin, v.118, p. 11851195 . 
Glazner, A.F., and Bartley, J.M., 2008, Reply to comments on "Is stoping a volumetrically significant pluton emplacement process?": Geological Society of America Bulletin, v. 120, p. 1082-1087.

Hamilton, W., 1978, Mesozoic tectonics of the western United States, in Howell, D.G., and McDougall, K.A., eds., Mesozoic paleogeography of the western United States: Los Angeles, Pacific Section, Society of Economic Paleontologists and Mineralogists Pacific Coast Paleogeography Symposium 2, p. 33-61.

Harper, B.E., Miller, C.F., Koteas, G.C., Cates, N.L., Wiebe, R.A., Lazzareschi, D.S., and Cribb, J.W., 2005, Granites, dynamic magma chamber processes and pluton construction; the Aztec Wash pluton, Eldorado Mountains, Nevada, USA: Transactions of the Royal Society of Edinburgh: Earth Sciences, v. 95, p. $277-$ 295.

Harwood, D.S., Fisher, G.R., and Hanson, R.E., 2014, Geologic map of part of eastern Placer County, northern Sierra Nevada, California (map and text): California Geological Survey Map Sheet 61, scale 1:48,000, 37 p.

Hutton, D.H.W., 1982, A tectonic model for the emplacement of the Main Donegal Granite, NW Ireland: Journal of the Geological Society of London, v. 139, p. 615631.

Hutton, D.H.W., 1996, The "space problem" in the emplacement of granite: Episodes, v. 19, p. 114-119.

Hutton, D.H.W., and Reavy, R.J., 1992, Strike-slip tectonics and granite petrogenesis: Tectonics, v. 11, p. 960-967.

Kamb, W.B., 1959, Ice petrofabric observations from Blue Glacier, Washington in relation to theory and experiment: Journal of Geophysical Research, v. 64, p. 1891-1909.

Loomis, A.A., 1983, Geology of the Fallen Leaf Lake 15' quadrangle, El Dorado County, California (map and text): California Division of Mines and Geology Map Sheet 32 , scale $1: 62,500,24 \mathrm{p}$.

Mahan, K.H., Bartley, J.M., Coleman, D.S., Glazner, A.F., and Carl, B.S., 2003, Sheeted intrusion of the synkinematic McDoogle pluton, Sierra Nevada, California: Geological Society of America Bulletin, v. 115, p. 1570-1582. 
Matzel, J.E.P., Bowring, S.A., and Miller, R.B., 2006, Time scales of pluton construction at differing crustal levels: Examples from the Mount Stuart and Tenpeak intrusions, North Cascades, Washington: Geological Society of America Bulletin, v. 118 , p. $1412-1430$.

Michel, J., Baumgartner, L., Putlitz, B., Schaltegger, U., and Ovtcharova, M., 2008, Incremental growth of the Patagonian Torres del Paine laccolith over $90 \mathrm{ky}$ : Geology, v. 36, p. 459-462.

Miller, C.F., Furbish, D.J., Walker, B.A., Claiborne, L.L., Koteas, C., Bleick, H.A., and Miller, J.S., 2011, Growth of plutons by incremental emplacement of sheets in crystal-rich host: Evidence from Miocene intrusions of the Colorado River region, Nevada, USA: Tectonophysics, v. 500, p. 65-77.

Miller, R.B., and Paterson, S.R., 1999, In defense of magmatic diapirs: Journal of Structural Geology, v. 21, p. 1161-1173.

Miller, R.B., and Paterson, S.R., 2001, Construction of mid-crustal sheeted plutons: Examples from the North Cascades, Washington: Geological Society of America Bulletin, v. 113, p. 1423-1442.

Mustart, D., and Horrigan, M., 2008, Hydrothermal pipes in eight granitic plutons in California: Evidence for evolution and migration of a magmatic volatile phase in epizonal silicic intrusions: Geophysical Research Abstracts, v. 10.

Paterson, S.R., and Vernon, R.H., 1995, Bursting the bubble of ballooning plutons: A return to nested diapirs emplaced by multiple processes: Geological Society of America Bulletin, v. 107, p. 1356-1380.

Paterson, S.R., Fowler, T.K., and Miller, R.B., 1996, Pluton emplacement in arcs: A crustal-scale exchange process: Transactions of the Royal Society of Edinburgh, Earth Sciences, v. 87, p. 115-123.

Paterson, S.R., Fowler, T.K., Schmidt, K.L., Yoshinobu, A.S., Yuan E.S., and Miller, R.B., 1998, Interpreting magmatic fabrics in plutons: Lithos, v. 44, p. 53-82.

Paterson, S.R., Pignotta, G.S., Farris, D., Memeti, V., Miller, R.B., Vernon, R.H., and Zák, J., 2008, Is stoping a volumetrically significant pluton emplacement process?: Geological Society of America Bulletin, v. 120, p. 1075-1079.

Paterson, S.R., Okaya, D., Memeti, V., Economos, R., and Miller, R.B., 2011, Magma addition and flux calculations of incrementally constructed magma chambers in continental margin arcs: Combined field, geochronologic, and thermal modeling studies: Geosphere, v. 7, p. 1439-1468. 
Pitcher, W.S., and Berger, A.R., 1972, The geology of Donegal: A study of granite emplacement and unroofing, Regional geology series: New York, WileyInterscience, $435 \mathrm{p}$.

Sabine, C.P., 1992, Magmatic interaction in the Crystal Range Suite, northern Sierra Nevada batholith, California [Ph.D. thesis]: Reno, University of Nevada, 163 p.

Saucedo, G.J., 2005, Geologic map of the Lake Tahoe basin, California and Nevada, 1:100,000 scale: California Geological Survey, Regional Geologic Map No. 4, scale 1:100000.

Teruya, L., 2005, Magmatic fabric relationships at two contacts in the Tuolumne Intrusive Suite [M.S. Thesis]: San Jose, California, San José State University, 84 p.

Tikoff, B., and Teyssier, C., 1992, Crustal-scale, en-echelon "P-shear" tensional bridges: A possible solution to the batholitic room problem: Geology, v. 20, p. 927-930.

Tobisch, O.T., Saleeby, J.B., Renne, P.R., McNulty, B., and Tong, W., 1995, Variations in deformation fields during development of a large-volume magmatic arc, central Sierra Nevada, California: Geological Society of America Bulletin, v. 107, p. 148166.

Wiebe, R.A., 1993, The Pleasant Bay layered gabbro-diorite, coastal Maine: Ponding and crystallization of basaltic injections into a silicic magma chamber: Journal of Petrology, v. 34, p. 461-489.

Wiebe, R.A., 1996. Mafic-silicic layered intrusions: the role of basaltic injections on magmatic processes and the evolution of silicic magma chambers: Transactions of the Royal Society of Edinburgh. Earth Sciences, v. 87, p. 233-242.

Wiebe, R.A., 2016, Mafic replenishments into floored silicic magma chambers: American Mineralogist, v. 101, p. 297-310.

Wiebe, R.A., and Collins, W.J., 1998, Depositional features and stratigraphic sections in plutons: implications for the emplacement and crystallization of granitic magmas: Journal of Structural Geology, v. 20, p. 1273-1289.

Wiebe, R.A., Blair, K.D., Hawkins, D.P., and Sabine, C.P., 2002, Mafic injections, in situ hybridization, and crystal accumulation in the Pyramid Peak granite, California: Geological Society of America Bulletin, v. 114, p. 909-920. 
Wiebe, R.A., Manon, M.R., Hawkins, D.P., and McDonough, W.F., 2004, Late-stage mafic injection and thermal rejuvenation of the Vinalhaven granite, Coastal Maine: Journal of Petrology, v. 45, p. 2133-2153.

Yoshinobu, A.S., and Barnes, C.G., 2008, Is stoping a volumetrically significant pluton emplacement process?: Geological Society of America Bulletin, v. 120, p. 10801081.

Žák, J., Paterson, S.R., and Memeti, V., 2007, Four magmatic fabrics in the Tuolumne batholith, central Sierra Nevada, California (USA): Implications for interpreting fabric patterns in plutons and evolution of magma chambers in the upper crust: Geological Society of America Bulletin, v. 119, p. 184-201.

Žák, J., Verner, K., and Týcová, P., 2008, Multiple magmatic fabrics in plutons: an overlooked tool for exploring interactions between magmatic processes and regional deformation?: Geological Magazine, v. 145, p. 537-551. 